\title{
43. NEOGENE DIATOM BIOSTRATIGRAPHY OF ODP LEG 113, WEDDELL SEA (ANTARCTIC OCEAN) ${ }^{1}$
}

\author{
Rainer Gersonde ${ }^{2}$ and Lloyd H. Burckle ${ }^{3}$
}

\begin{abstract}
Diatom assemblages recovered during ODP Leg 113 at eight sites in the Weddell Sea (Atlantic sector of the circumAntarctic Ocean) provide new insights into southern high-latitude Neogene diatom biostratigraphy. The excellent sections recovered by ODP Leg 113 Sites 689 and 690 (Maud Rise, southeast Weddell Sea, Antarctic Ocean) were chosen for the establishment of a revised Neogene Antarctic diatom zonation. Altogether, 16 diatom zones are described as well as several stratigraphically useful diatom datums of late early Miocene to Pleistocene age. Six zones established by previous authors are partly modified or renamed, and 10 new zones are proposed. The zones are calibrated directly to the geomagnetic time scale, which provides a chronological framework for the zones and permits comparisons of Neogene Antarctic diatom events with events described from the low and northern high latitudes. This is the first attempt at direct calibration of Miocene Antarctic diatom zones with the geomagnetic time scale.
\end{abstract}

\section{INTRODUCTION}

Leg 113 of the Ocean Drilling Program hydraulically piston cored (APC) or rotary drilled nine sites in the Weddell Sea region, Antarctic Ocean, to investigate the Cenozoic paleoclimatic and paleoceanographic history of the southern high latitudes. Neogene sediment sequences were recovered at eight sites, all located in the present-day Antarctic cold-water belt south of the Polar Front. These included open-ocean pelagic biogenic sediments at Maud Rise (Sites 689 and 690), hemipelagic sequences recovered at the Antarctic continental margin (Sites 692 and 693) and at the eastern South Orkney microcontinent (Sites 695, 696, and 697), and a deep-sea turbiditic to hemipelagic sequence in the Weddell Sea abyssal plain (Site 694) (Fig. 1). Leg 113 was the first to use the hydraulic piston coring technique in Antarctic sediments, and at some sites gathered well preserved and continuously recovered sediment sequences, which can be used for the establishment of an integrated bio- and magneto-stratigraphy.

McCollum (1975) described the first detailed diatom biostratigraphic zonation for the Oligocene to the Pleistocene based on rotary-drilled material recovered during Deep Sea Drilling Project (DSDP) Leg 28 in the Pacific sector of the Antarctic Ocean. Thirteen zones were established, of which eight zones defined for the Pleistocene and the Pliocene time interval (last 5 m.y.) were correlated to the geomagnetic time scale based on additional piston core studies (Fig. 2). However, the origin of the paleomagnetic data used was not identified. Schrader (1976) re-examined part of McCollum's material. He revised the Miocene and Oligocene zonation of McCollum (1975) based on a comprehensive study of DSDP Site 278 , because he found significant differences in the ranges of key species.

Later, Weaver and Gombos (1981) summarized the developments of southern high-latitude diatom biostratigraphy and proposed a regionally applicable Neogene (last 24 m.y.) diatom zonation using species easily recognized and with a broad geographic distribution. Based on a revised and comparative study

\footnotetext{
${ }^{1}$ Barker, P. F., Kennett, J. P., et al., 1990. Proc. ODP, Sci. Results, 113: College Station, TX (Ocean Drilling Program).

2 Alfred Wegener Institute for Polar and Marine Research, Columbusstraße, D-2850 Bremerhaven, Federal Republic of Germany.

${ }^{3}$ Lamont-Doherty Geological Observatory of Columbia University, Palisades, New York 10984.
}

of the DSDP Sites 278 and 266, and a number of piston cores from the Pacific and Indian sector of the Southern Ocean, Weaver and Gombos defined 16 zones. The five youngest zones spanning the last 2.7 m.y. were taken from McCollum (1975), six zones defined by McCollum (1975) or Schrader (1976) were redefined, and five new zones were established. Weaver and Gombos (1981) correlated the late late Miocene to Pleistocene diatom zones (last $8 \mathrm{~m}$.y.) with the geomagnetic time scale, but again the original paleomagnetic data taken from piston core studies were not shown.

Ciesielski (1983) revised the zonation of Weaver and Gombos (1981) based on DSDP Leg 71 cores from the Southwest (Subantarctic) Atlantic and described five additional Neogene zones. The late middle Miocene, and Pliocene-Pleistocene zones were correlated to the geomagnetic time scale. However, reliable paleomagnetic data exist only for the Pliocene and Pleistocene (Salloway, 1983), while the correlation to the Miocene zones is weak because of the questionable paleomagnetic data interpretation of Ledbetter (1983). This leads to poorly defined age assignments of the Miocene zonal boundaries.

Critical and yet unresolved points of the Neogene diatom zonation established by Weaver and Gombos (1981) and Ciesielski (1983) are:

1. Most of the diatom zones are defined by the LAD (last appearance datum) of species, a definition which causes problems because reworking of older species into younger sediments by bottom water activity is common in the Southern Ocean basins.

2. Some zones are defined by the LAAD (last abundant appearance datum) of species-a definition which is, however, not supported by quantitative measurements.

3. Several species used as biostratigraphic marker species are poorly described and documented, which leads to misidentifications and, as a consequence, to incorrect age assignments.

4. The Miocene zones are not directly tied to the geomagnetic time scale.

5. Some Miocene zones range up to $4 \mathrm{~m} . \mathrm{y}$. in duration and should be refined.

For improvement and refinement of the Neogene diatom biostratigraphic zonation for the Antarctic Ocean we chose Holes 689B and 690B (Maud Rise) which are the focus of this paper. In both holes a well preserved and continuously recovered Neo- 


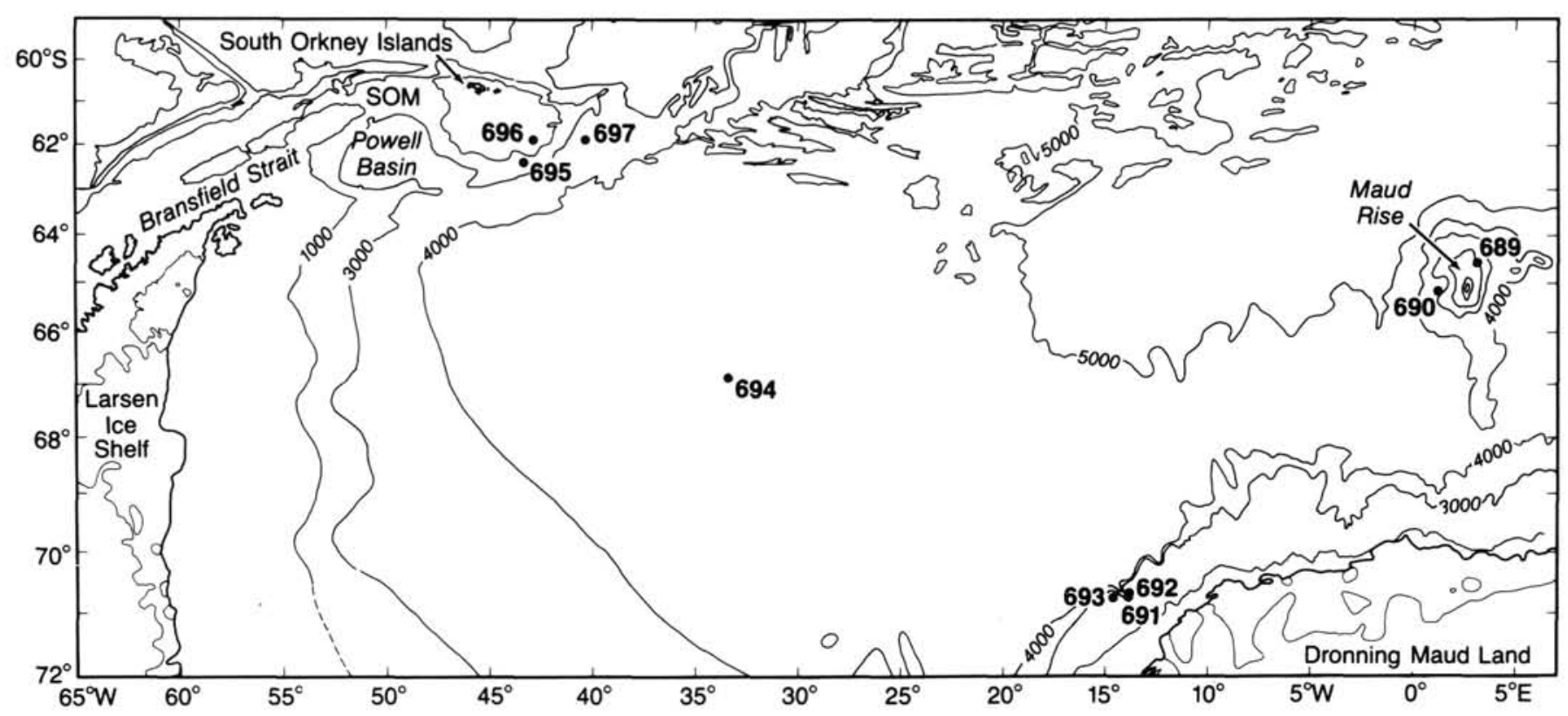

Figure 1. Location of Leg 113 sites in the Weddell Sea. Contours in meters. SOM = South Orkney microcontinent.

gene sediment sequence was obtained, bearing moderately to well preserved diatom assemblages. Despite low sedimentation rates of the pelagic biogenic sediment sequences we could improve especially the early Pliocene and late and middle Miocene diatom zonation, and correlate the species ranges with the magnetostratigraphic polarity record established by Spieß (this volume). As far as possible we used the first appearance datum (FAD) of species easily identified for the definition of zonal boundaries. However, for zones of the late Pliocene and Pleistocene time period only the LAD of diatom species was available for zonal definition (Table 1). The combination of Holes 689B and $690 \mathrm{~B}$ resulted in a relatively complete Pliocene to late early Miocene sequence. The comparison of both holes was used to test coherency of the biostratigraphic results and to confirm the absolute age determination of species ranges and zonal boundaries.

Other sites with Neogene sections were rotary drilled (Site 693), or had incomplete recovery (Sites 694 and 696), or penetrated only Pliocene-Pleistocene sediments with in part poorly preserved siliceous microfossil assemblages (Sites 695 and 697). A biostratigraphic age assignment of these sites is presented using the biostratigraphic zonation established from Holes 689B and 690B. Due to a later date of submission the biostratigraphic age assignment of the Neogene sections recovered at Sites 693697 are slightly different than those in the biostratigraphic synthesis chapter by Gersonde et al. (this volume).

\section{MATERIAL AND METHODS}

Samples were taken aboard JOIDES Resolution during Leg 113. Micropaleontological and paleomagnetic samples were taken at nearly the same core depths. In Holes 689B and 690B, which are the focus of this study, we generally investigated two samples per section (at $\sim 28$ and $115 \mathrm{~cm}$ of each section) which were supplemented by additional samples when needed. At Holes 693A, 693B, 694B, 694C, 695A, 696A, 696B, 697A, and 697B the spacing of investigated samples is generally larger (only one or two samples per core). For quantitative and qualitative diatom study, microscope slides with randomly distributed microfossils were used. The cleaning of the sediment samples, preparation of permanent mounts for light microscopy (using the resin Mountex, nd $=1.67$ ) and SEM investigations were carried out according to methods developed by A. Abelmann, U. Bok, R. Gersonde, and U. Treppke (in prep.). Light microscope investigations were made with a Leitz Orthoplan microscope with apochromatic optics. Species identification and counting were conducted routinely at $\times 630$ or $\times 1000$. Light micrographs were made with an automatic Leitz Orthomate camera, and scanning electron microscope investigations with a Philips SEM 515. Species abundance was determined through quantitative studies on Miocene sequences of Hole $689 \mathrm{~B}$. The counting procedure, calculation of absolute microfossil numbers, and definition of counting units follow those of Schrader and Gersonde (1978). In general more than 400 diatom valves were counted per sample. Semiquantitative diatom species abundance classes are: $\mathrm{A}=$ abundant $(>30 \%$ of total assemblage); $\mathrm{C}=$ common $(15 \%-$ $30 \%) ; \mathrm{F}=$ few $(3 \%-15 \%) ; \mathrm{R}=$ rare $(<3 \%)$; and $\mathrm{T}=$ trace (species encountered only sporadically). Preservation was considered good if the preserved diatom assemblages did not show obvious signs of dissolution. Moderate preservation was characterized by evidence of slight dissolution and breakage. Preservation was regarded as poor when only robust silicified valves were preserved, combined with strong breakage.

The absolute age assignment is according to the geomagnetic polarity time scale of Berggren et al. (1985). For designation of paleomagnetic events we used a modified nomenclature proposed by Spieß (this volume) which follows the scheme proposed by Tauxe et al. (1984, figs. 2, 3). This nomenclature was also used in the Initial Reports volume of ODP Leg 113 (Barker, Kennett, et al., 1988).

\section{NEOGENE ANTARCTIC DIATOM ZONATION}

The Neogene Antarctic diatom zonation proposed in this study represents a time interval spanning the early Miocene to the Pleistocene. Sixteen zones are defined (Table 1, Fig. 3) which were correlated to the geomagnetic record in Holes 689B and 690B drilled on Maud Rise. Two zones were taken from McCollum (1975), unchanged or modified. Four lower and middle Miocene zones, originally established by Schrader (1976), or Weaver and Gombos (1981), were redefined. Ten middle and upper Miocene and Pliocene-Pleistocene zones are new. The oldest Thalassiosira spumellaroides Zone is tentative, because the data base to define this zone is limited. A comparison of the described Neo- 


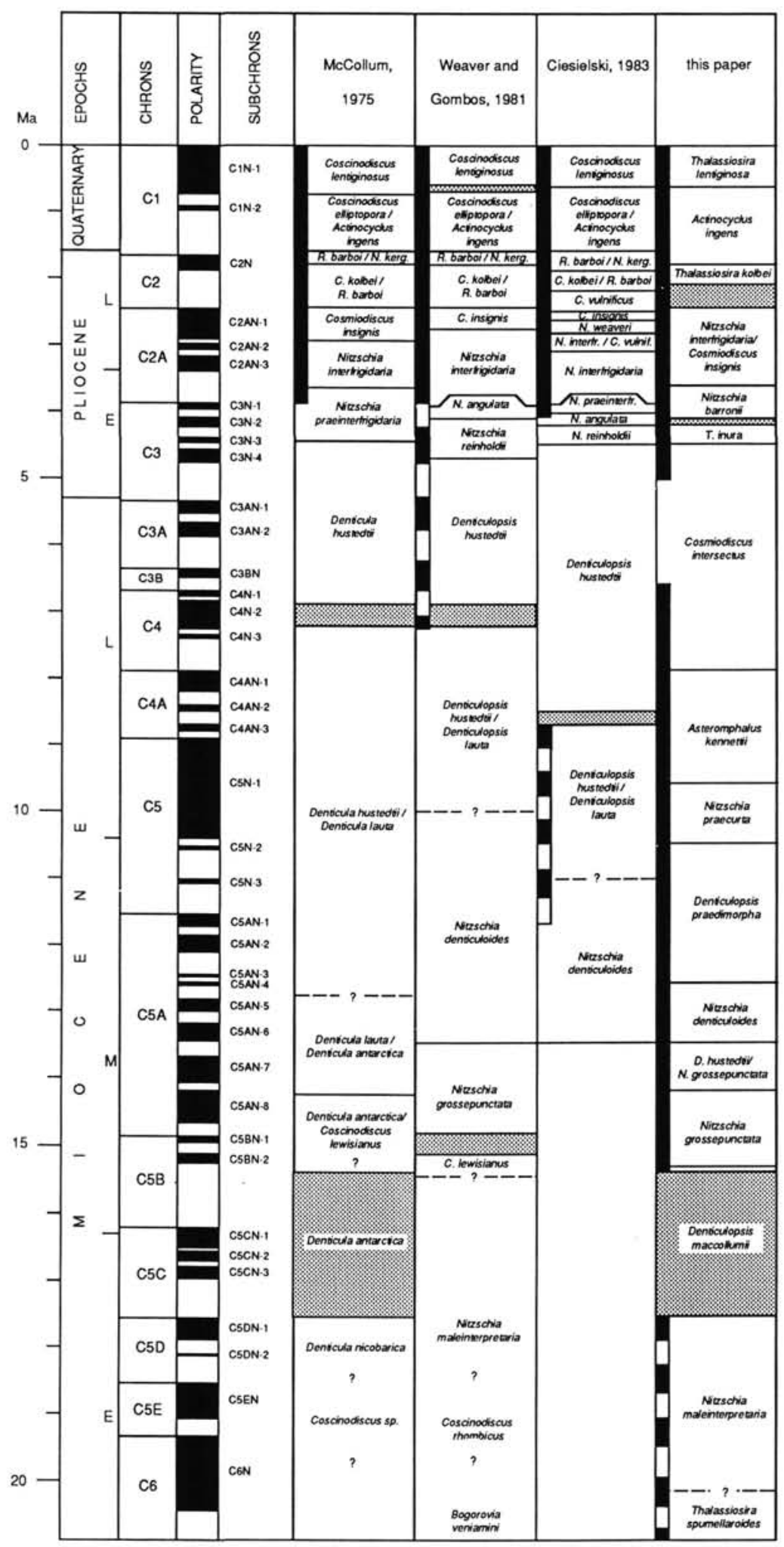

Figure 2. Comparison of Neogene diatom zonations for the southern high latitudes established by McCollum (1975), Weaver and Gombos (1981), Ciesielski (1983), and the present study, and their correlation to the paleomagnetic time scale. Direct correlation between the zonations and the geomagnetic stratigraphy is indicated by continuous bars; correlation to the paleomagnetic stratigraphy by extrapolation and intervals with uncertain identification of the paleomagnetic polarity record are indicated by dashed bars. Shaded zone intervals indicate range of uncertainty of zonal boundary age. 
Table 1. Neogene Antarctica diatom zonation, its definition and age range.

\begin{tabular}{|c|c|c|c|c|}
\hline Antarctic diatom zones & Age range $(\mathrm{Ma})$ & Definition of base & Definition of top & Other important datums \\
\hline $\begin{array}{l}\text { Thalassiosira lentiginosa Zone } \\
\text { (McCollum 1975, renamed herein) }\end{array}$ & $0.6-0$ & LAD Actinocyclus ingens & Recent & \\
\hline Actinocyclus ingens Zone (new) & ca. $1.8-0.6$ & LAD Thalassiosira kolbei & LAD Actinocyclus ingens & \\
\hline Thalassiosira kolbei Zone (new) & $(2.5-2.1)-$ ca. 1.8 & LAD Cosmiodiscus insignis & LAD Thalassiosira kolbei & \\
\hline $\begin{array}{l}\text { Nitzschia interfrigidaria/Cosmiodiscus } \\
\text { insignis Zone (new) }\end{array}$ & $3.6-(2.5-2.1)$ & FAD Nitzschia interfrigidaria & LAD Cosmiodiscus insignis & \\
\hline Nitzschia barronii Zone (new) & $(4.2-4.1)-3.6$ & FAD Nitzschia barronii & FAD Nitzschia interfrigidaria & \\
\hline Thalassiosira inura Zone (new) & $4.47-(4.2-4.1)$ & FAD Thalassiosira inura & FAD Nitzschia barronii & $\begin{array}{l}\text { 4.3 Ma FAD Rouxia heteropolara } \\
\text { 4.3 Ma FAD Thalassiosira complicata }\end{array}$ \\
\hline Cosmiodiscus intersectus Zone (new) & 7.9-4.47 & FAD Cosmiodiscus intersectus & FAD Thalassiosira inura & $\begin{array}{l}\text { 7.1 Ma LAD Asteromphalus kennettii } \\
\text { ca. 7.3 Ma LAAD Denticulopsis hustedtii } \\
\text { 7.9-7.8 Ma FAD A. ingens var. ovalis }\end{array}$ \\
\hline Asteromphalus kennettii Zone (new) & $9.6-7.9$ & FAD Asteromphalus kennettii & FAD Cosmiodiscus intersectus & \\
\hline Nitzschia praecurta Zone (new) & $10.5-9.6$ & FAD Nitzschia praecurta & FAD Asteromphalus kennettii & $\begin{array}{l}\text { 9.9-9.8 Ma LAAD Denticulopsis dimorpha } \\
\text { 10.4 Ma LAD Denticulopsis praedimorpha }\end{array}$ \\
\hline Denticulopsis praedimorpha Zone (new) & $12.6-10.5$ & FAD Denticulopsis praedimorpha & FAD Nitzschia praecurta & $\begin{array}{l}\text { 10.9-10.8 Ma LAAD D. praedimorpha } \\
\text { 11.0-10.9 Ma FAAD D. dimorpha } \\
\text { 11.5 Ma LAD Nitzschia denticuloides } \\
\text { 12.3 Ma LAD A. ingens var. nodus }\end{array}$ \\
\hline $\begin{array}{l}\text { Nitzschia denticuloides Zone } \\
\text { (Weaver and Gombos 1981, redefined herein) }\end{array}$ & $13.5-12.6$ & $\begin{array}{l}\text { 1. FAD Nitzschia denticuloides } \\
\text { 2. LAD N. grossepunctata }\end{array}$ & FAD Denticulopsis praedimorpha & \\
\hline $\begin{array}{l}\text { Denticulopsis hustedtii/Nitzschia } \\
\text { grossepunctata Zone (new) }\end{array}$ & $14.2-13.5$ & FAD Denticulopsis hustedtii & $\begin{array}{l}\text { 1. FAD Nitzschia denticuloides } \\
\text { 2. LAD Nitzschia grossepunctata }\end{array}$ & \\
\hline $\begin{array}{l}\text { Nitzschia grossepunctata Zone } \\
\text { (Weaver and Gombos 1981, redefined herein) }\end{array}$ & $15.3-14.2$ & FAD Nitzschia grossepunctata & FAD Denticulopsis hustedtii & $\begin{array}{l}\text { 14.4 Ma LAD Denticulopsis maccollumii } \\
\text { 14.9 Ma FAD A. ingens var. nodus } \\
\text { 15.2 Ma FAD Actinocyclus ingens }\end{array}$ \\
\hline $\begin{array}{l}\text { Denticulopsis maccollumii Zone } \\
\text { (McCollum 1975, redefined herein) }\end{array}$ & $?(17.6-15.4)-15.3$ & FAD Denticulopsis maccollumii & FAD Nitzschia grossepunctata & \\
\hline $\begin{array}{l}\text { Nitzschia maleinterpretaria Zone } \\
\text { (Weaver and Gombos 1981, redefined herein) }\end{array}$ & $? 20.2-?(17.6-15.4)$ & FAD Nitzschia maleinterpretaria & FAD Denticulopsis maccollumii & \\
\hline $\begin{array}{l}\text { Thalassiosira spumellaroides Zone } \\
\text { (Schrader 1976, redefined herein) }\end{array}$ & $>? 20.5-? 20.2$ & FAD Thalassiosira spumellaroides & FAD Nitzschia maleinterpretaria & ?19.6 Ma FAD Thalassiosira fraga \\
\hline
\end{tabular}




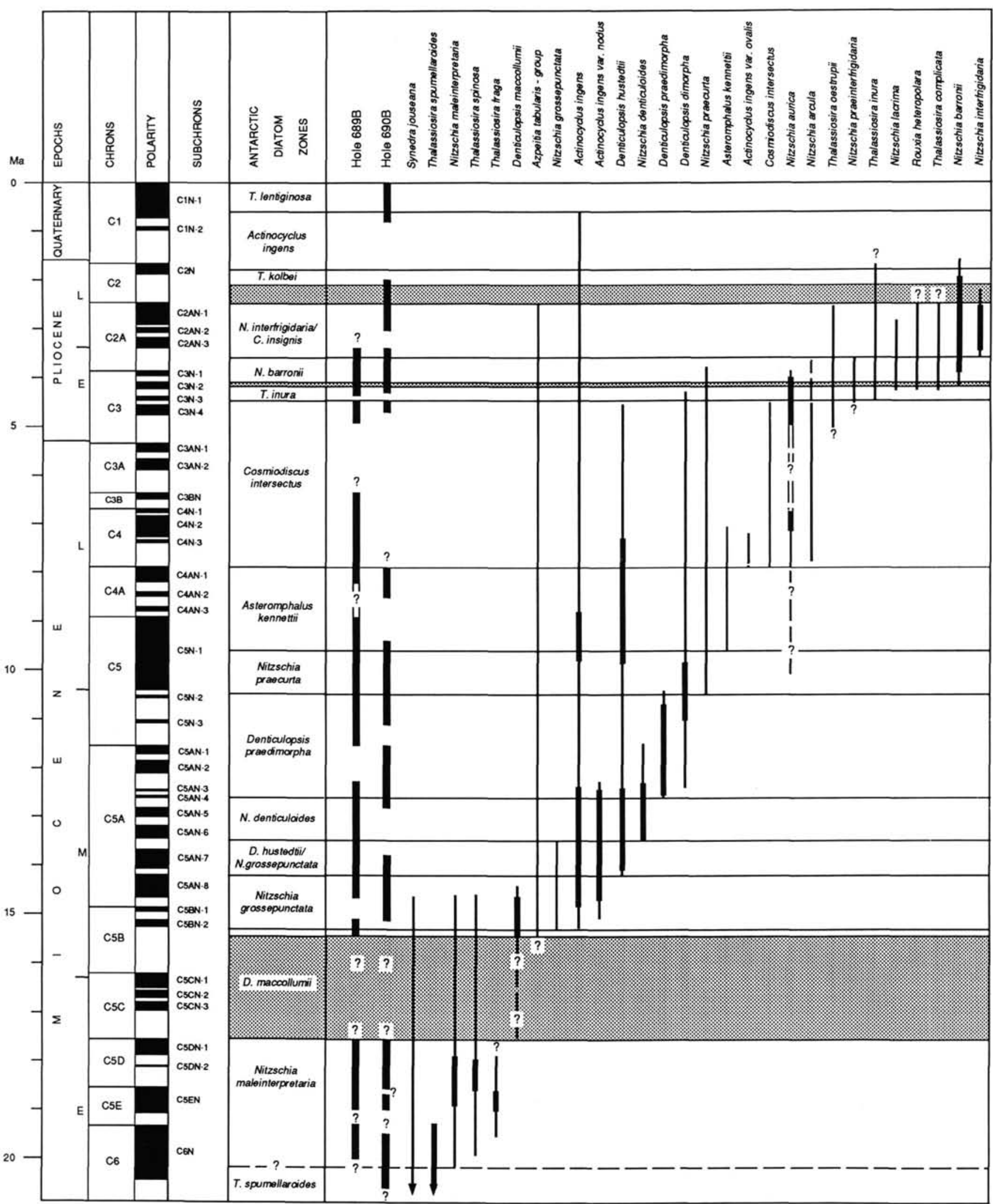

Figure 3. Ranges of selected Neogene diatom species, Neogene Antarctic diatom zonation as herein defined, and stratigraphic intervals recovered in Holes 689B and 690B correlated to the standard geomagnetic time scale. Thickened bar portions of species ranges indicate intervals where species in general make up more than $15 \%$ of total assemblage. 
gene Antarctic diatom zonation with the previous zonations of McCollum (1975), Weaver and Gombos (1981), and Ciesielski (1983) is given in Figure 2.

The ages of the zonal boundaries and the ranges of selected diatom species (Fig. 3) are based on a combined and detailed stratigraphic interpretation of the Neogene sections in Holes 689B and 690B. The geomagnetic polarity record established for the Neogene of Holes 689B and 690B by Spieß (this volume) was interpreted based on the magnetic polarity pattern and the occurrence of diatom species. Additional magnetostratigraphic information from Holes 695A, 697A, and 697B was contributed by Hamilton and O'Brien (unpubl. data, also see Gersonde et al., this volume). Age assignment of the Pliocene-Pleistocene geomagnetic record was done according to previous diatom zonations, and based on additional radiolarian biostratigraphic data contributed by Lazarus (this volume). Additional information came from the study of piston and gravity cores recovered during Polarstern cruise ANT IV/4 on the Maud Rise and the Weddell Sea area (Gersonde et al., in prep.). The interpretation of the Miocene record was supported by comparison of Antarctic species ranges with calibrated diatom species ranges in the low latitudes and mid to high latitudes of the North Pacific according to the compilation of Barron (1985). Further important support was contributed by Abelmann (this volume) for the early and middle Miocene time interval which now allows a tentative age assignment for the early Miocene diatom zones. Interpretation of the lower Miocene sequences was difficult due to the occurrence of disconformities which strongly disturb the geomagnetic scheme. The combined stratigraphic interpretation was tested for coherency by comparison of both Maud Rise sites and was then used for the establishment of detailed age-depth diagrams for the Neogene of Holes 689B and 690B (Figs. 5 and 7). Zonal boundary ages and ages of species ranges were then calculated assuming constant sedimentation rates between the various geomagnetic and biostratigraphic datum points. The subbottom depth (mbsf) of zonal boundaries, species ranges, and disconformities were calculated as the midpoint between subbottom depths of studied samples below and above these events or boundaries. In general, ages of the zonal boundaries or species ranges given in $\mathrm{Ma}$ are rounded to $10^{5} \mathrm{yr}$ values.

Problematic stratizraphic intervals are in the upper upper Miocene, the middle middle Miocene, and below the lower middle Miocene. A disconformity occurs near the Miocene/Pliocene boundary in Holes 689B and 690B (Figs. 5, 7). Accurate stratigraphic placement of the sequences immediately below this disconformity is problematic. These can only be based on the interpretation of the geomagnetic polarity pattern because no independent biostratigraphic datums calibrated to the time scale are available for this time interval. As a prominent tie-point for the interpretation of the late Miocene polarity pattern we used the occurrence of Subchron $\mathrm{C} 5 \mathrm{~N}-1$. A possible point of criticism may be our interpretation of two distinct middle middle Miocene geomagnetic events in Holes 689B and 690B to be Subchrons $\mathrm{C} 5 \mathrm{~N}-3$ and $\mathrm{C} 5 \mathrm{~N}-4$, respectively. Our interpretation is supported by the FAD of Denticulopsis praedimorpha which can be placed approximately between these subchrons at $\sim 12.6$ Ma (Figs. 4, 6). The same age for the FAD of D. praedimorpha is reported by Barron (1985) for the high and mid-latitudes of the North Pacific (Table 2). However, according to Berggren et al. (1985) both subchrons are short-ranging (Subchron C5N-4: 12.62-12.58 Ma; Subchron C5N-3: 12.49-12.46 Ma). Thus, considering the general low sedimentation rate of $\sim 4-8 \mathrm{~m} / \mathrm{m} . \mathrm{y}$. in the middle Miocene of Holes 689B and 690B, both events should not be as distinctly marked as found in both holes. More problematic is the age assignment of the lower Miocene sequences in Holes 689B and 690B, separated from upper Oligocene and middle Miocene sequences by a disconformity at both holes
(Figs. 4, 6). The stratigraphic interpretation of the lower Miocene sediments is still tentative and was primarily based on radiolarian biostratigraphic results of Abelmann (this volume). Her results rely on a comparison of radiolarian biostratigraphic data of Holes 689B and 690B, with data from Leg 120 Site 571.

\section{Thalassiosira lentiginosa Partial-Range Zone}

Author. McCollum (1975), renamed herein.

Definition of top. recent.

Definition of base. LAD Actinocyclus ingens.

Age. late Pleistocene, 0-0.6 Ma.

Paleomagnetic correlation. The zonal boundary falls within the lowermost portion of the Brunhes Chron $(\mathrm{C} 1 \mathrm{~N}-1)$.

Discussion and remarks. Estimations of Ciesielski (1983), based on Islas Orcadas piston core IO11-70 from the southeast Atlantic, result in an age of $\sim 0.62 \mathrm{Ma}$ for the LAD of $A$. ingens. Gersonde and Treppke (in prep.) report an age of $0.6 \mathrm{Ma}$ from Polarstern gravity core PS $1225-$ 1 , recovered in the Atlantic sector of the Antarctic Ocean, at $54^{\circ} 31^{\prime} \mathrm{S}$, $10^{\circ} 17^{\prime} \mathrm{E}$. The zone was renamed because the nominate species for the zone, originally named Coscinodiscus lentiginosus, was transferred to Thalassiosira lentiginosa (Fryxell, 1977). For correlation with diatom zones of previous authors compare Fig. 2.

\section{Actinocyclus ingens Partial-Range Zone}

Authors. Gersonde and Burckle, herein.

Definition of top. LAD Actinocyclus ingens.

Definition of base. LAD Thalassiosira kolbei.

Age. latest Pliocene to early Pleistocene, $\sim 1.8-0.6 \mathrm{Ma}$.

Paleomagnetic correlation. The zone ranges from the lower part of the Olduvai Subchron of the Matuyama Chron (Subchron C2N) to the lowermost portion of the Brunhes Chron $(\mathrm{C} 1 \mathrm{~N}-1)$.

Discussion and remarks. The age assignment for the base of this zone was estimated based on data of McCollum (1975), who placed the LAD of $T$. kolbei into Subchron C2N (age range: 1.66-1.88 Ma), and Ciesielski (1983), who found this LAD at the base of Subchron C2N. At Leg 113 sites the critical time interval was not recovered (Hole 689B), or incompletely present due to occurrence of a hiatus (Hole 690B), or the sediments are barren in diatoms (Holes 693A, 694B, 697B), or strongly condensed due to extremely low sedimentation rates (Holes 695A, 696A). The $A$. ingens Zone corresponds stratigraphically to the Coscinodiscus elliptopora/Actinocyclus ingens Zone and the short ranging Rhizosolenia barboi/Nitzschia kerguelensis Zone of McCollum (1975). The latter zone was omitted because of the rare to trace occurrence of the nominate species Rhizosolenia barboi in late Pliocene-early Pleistocene Antarctic sediments. The same is true for C. elliptopora, which is scattered in Pleistocene and Pliocene sediments of the Weddell Sea (Gersonde et al., in prep.).

\section{Thalassiosira kolbei Partial-Range Zone}

Authors. Gersonde and Burckle, herein

Definition of top. LAD Thalassiosira kolbei.

Definition of base. LAD Cosmiodiscus insignis.

Age. late Pliocene, (2.5-2.1)- 1.8 Ma.

Paleomagnetic correlation. The base of the zone cannot be defined precisely. It is between the Gauss/Matuyama Chron boundary (Chron $\mathrm{C} 2 / \mathrm{C} 2 \mathrm{~A}$ boundary) and about midway between the Chron $\mathrm{C} 2 / \mathrm{C} 2 \mathrm{~A}$ boundary and the Olduvai Subchron of the Matuyama Chron (Subchron $\mathrm{C} 2 \mathrm{~N}$ ). The top of the zone is at the lower part of the Olduvai Subchron of the Matuyama Chron (Subchron C2N).

Discussion and remarks. The Thalassiosira kolbei Zone correlates, at least in part, to the Coscinodiscus kolbei/Rhizosolenia barboi Zone of McCollum (1975) as redefined by Weaver and Gombos (1981). The age assignment for the LAD of $C$. insignis, which defines the base of the $T$. kolbei Zone, is still under discussion. Thus we can only indicate a range for the base of the T. kolbei Zone. McCollum (1975) and Ciesielski (1983), and Weaver and Gombos (1981) place the LAD of $C$. insignis just below, and at the Gauss/Matuyama Chron boundary (Chron C2/ C2A boundary), respectively. Our data (Burckle et al., in prep.) show a distinct abundance maximum of $C$. insignis in the upper portion of the Gauss Chron and an upper boundary of the abundance maximum around the Gauss/Matuyama Chron boundary. The drop in abundance is probably not equivalent to the $\mathrm{LAD}$ of $C$. insignis because the species was found to occur in minor amounts in the lower portion of the Matuyama Chron. However, we cannot exclude the possibility that the occurrence 
Table 2. Age range of selected diatom species in Neogene Antarctic sediments, as recovered from Holes 689B and 690B, and comparison to species ranges as recovered from the lowlatitude Ocean and the middle- and high-latitude Pacific Ocean (data from Barron 1983, 1985).

\begin{tabular}{|c|c|c|c|}
\hline Species & $\begin{array}{c}\text { Southern Ocean } \\
\text { (Holes 689B and 690B) } \\
\text { (Ma) }\end{array}$ & $\begin{array}{c}\text { Low latitudes } \\
\text { (Barron 1983, 1985) } \\
\text { (Ma) }\end{array}$ & $\begin{array}{c}\text { High and mid-latitude } \\
\text { N-Pacific (Barron 1985) } \\
\text { (Ma) }\end{array}$ \\
\hline $\begin{array}{l}\text { Actinocyclus ingens } \\
\text { A. ingens var. nodus } \\
\text { A. ingens var. ovalis } \\
\text { Asteromphalus kennettii } \\
\text { Azpeitia tabularis group }\end{array}$ & $\begin{array}{c}15.2-0.6 \\
\text { ca. } 14.9-12.3 \\
(7.9-7.8)-7.2 \\
9.6-7.1 \\
15.4-\text { ca. } 2.5\end{array}$ & $15.5-11.5$ & $\begin{array}{l}16.8-? 4.4 \\
15.2-13.7\end{array}$ \\
\hline $\begin{array}{l}\text { Cosmiodiscus intersectus } \\
\text { Denticulopsis dimorpha } \\
\text { D. hustedtii } \\
\text { D. maccollumii } \\
\text { D. praedimorpha }\end{array}$ & $\begin{array}{c}7.9-\mathrm{ca} .4 .5 \\
12.4-4.3 \\
14.2-4.5 \\
?(17.6-15.4)-14.4 \\
12.6-10.4\end{array}$ & $14.3-8.4$ & $\begin{array}{c}8.9-8.4 \\
14.2-4.3 \\
\\
12.6-10.4\end{array}$ \\
\hline $\begin{array}{l}\text { Nitzschia arcula } \\
\text { N. aurica } \\
\text { N. barronii } \\
\text { N. denticuloides } \\
\text { N. grossepunctata }\end{array}$ & $\begin{array}{c}7.8-\text { ca. } 3.6 \\
7.9^{*}-3.8 \\
(4.2-4.1)-\text { ca. } 1.5 \\
13.5-11.5 \\
15.3-13.5\end{array}$ & & \\
\hline $\begin{array}{l}\text { N. interfrigidaria } \\
\text { N. lacrima } \\
\text { N. maleinterpretaria } \\
\text { N. praecurta } \\
\text { N. praeinterfrigidaria }\end{array}$ & $\begin{array}{c}3.6-?(2.5-2.1) \\
4.3-\text { ca. } 2.8 \\
? 20.2-14.6 \\
10.5-3.8 \\
? 4.5-3.6\end{array}$ & $18.8-15.6$ & \\
\hline $\begin{array}{l}\text { Rouxia heteropolara } \\
\text { Synedra jouseana } \\
\text { Thalassiosira complicata } \\
\text { T. fraga } \\
\text { T. inura }\end{array}$ & $\begin{array}{c}4.3 \text {-ca. } 2.5 \\
\text { Oligocene-14.6 } \\
4.3 \text {-ca. } 2.5 \\
? 19.6-?(<17.6->15.4) \\
4.47-? 1.7\end{array}$ & $\begin{array}{c}\text { Oligocene-10.4 } \\
19.9-16.2\end{array}$ & ca. $19.6-16.5$ \\
\hline $\begin{array}{l}\text { T. oestrupii } \\
T . \text { spinosa } \\
\text { T. spumellaroides }\end{array}$ & $\begin{array}{c}>4.9-\text { ca. } 2.5 \\
? 19.8-14.6 \\
>20.5-?<19.5\end{array}$ & $\begin{array}{l}\text { 5.1-recent } \\
\text { ca. } 23.2-18.0 \\
\text { ca. } 21.7-17.5\end{array}$ & $\begin{array}{l}\text { 5.1-recent } \\
\text { ca. } 23.2-18.0 \\
\text { ca. } 21.7-17.0\end{array}$ \\
\hline
\end{tabular}

Note: ${ }^{*}=$ first consistent occurrence.

of $C$. insignis in the lower Matuyama Chron is due to reworking by bottom water activity. This stratigraphic problem cannot be resolved based on Leg 113 material because the critical interval is not well represented in the investigated holes.

\section{Nitzschia interfrigidaria/Cosmiodiscus insignis Concurrent-Range Zone}

Authors. Gersonde and Burckle, herein.

Definition of top. LAD Cosmiodiscus insignis.

Definition of base. FAD Nitzschia interfrigidaria.

Age. late early Pliocene-late Pliocene, 3.6-(2.5-2.1) Ma.

Paleomagnetic correlation. The base of the zone is in the lower portion of the upper Gilbert reversed time interval (between Subchrons C2AN-3 and $\mathrm{C} 3 \mathrm{~N}-1)$. The top of the zone cannot be defined precisely. It is between the Gauss/Matuyama Chron boundary (Chron $\mathrm{C} 2 / \mathrm{C} 2 \mathrm{~A}$ boundary) and about midway between the Chron $\mathrm{C} 2 / \mathrm{C} 2 \mathrm{~A}$ boundary and the Olduvai Subchron of the Matuyama Chron (Subchron $\mathrm{C} 2 \mathrm{~N}$ ).

Discussion and remarks. The Nitzschia interfrigidaria/Cosmiodiscus insignis Zone includes the Nitzschia interfrigidaria Zone and the Cosmiodiscus insignis Zone of McCollum (1975; Fig. 2). The base of the latter zone was defined by the LAD of $N$. interfrigidaria placed at $2.85 \mathrm{Ma}$. However, we found $N$. interfrigidaria ranging into the lowermost portion of the Matuyama Chron (lower part of Chron C2). For discussion of the upper boundary age assignment compare the discussion and remarks of the T. kolbei Zone.

The age of the FAD of $N$. interfrigidaria found in the investigated ODP Leg 113 holes is slightly younger compared to those reported by previous authors. McCollum (1975) places the FAD of $N$. interfrigidaria at the base of Subchron C3N-1 (3.97 Ma). Weaver and Gombos (1981) indicate an age of $3.9 \mathrm{Ma}$ (within Subchron $\mathrm{C} 3 \mathrm{~N}-1$ ), and Ciesielski (1983) places the FAD at $4.02 \mathrm{Ma}$ (between Subchrons C3N-1 and C3N2). These differences in FAD age assignment may be due to different species concepts for the definition of $N$. interfrigidaria. For an emended description of $N$. interfrigidaria compare Gersonde (in press).
In the lower portion of the $N$. interfrigidaria Zone we note abundant occurrences of Nitzschia barronii. Thalassiosira inura is another characteristic species of the zone.

\section{Nitzschia barronii Partial-Range Zone}

Authors. Gersonde and Burckle, herein.

Definition of top. FAD Nitzschia interfrigidaria.

Definition of base. FAD Nitzschia barronii.

Age. early Pliocene, (4.2-4.1)-3.6 Ma.

Paleomagnetic correlation. The base of the zone was placed within Subchron $\mathrm{C} 3 \mathrm{~N}-2$ between 4.2 and $4.1 \mathrm{Ma}$. The top is in the lower portion of the reversed time interval between Subchrons C2AN-3 and C $3 \mathrm{~N}$ 1 .

Discussion and remarks. $N$. barronii is very probably conspecific with $N$. angulata, the nominate species of the $N$. angulata Zone defined by Weaver and Gombos (1981). Weaver and Gombos refer to the extant Nitzschia angulata (O'Meara) Hasle, a species which was not found in early Pliocene sediments of Leg 113 sites and Polarstern piston cores recovered in the Weddell Sea. Unfortunately Weaver and Gombos did not photographically document the species, nor was this done by Ciesielski (1983), who also used the FAD of $N$. angulata. Barron (1985) labels a species as $N$. angulata which, based on its photographically documented outline (fig. 14.14 in Barron, 1985), is very probably conspecific with $N$. barronii.

In Holes 689B and 690B (Figs. 4, 6) the FAD of $N$. barronii is correlated to the lower part of Subchron C3N-2 ( 4.2 Ma). Denoting the same age it was found in Polarstern piston core PS 1467-1, also recovered on Maud Rise. However, at Holes 695A and 697B, southeast of the South Orkney Islands, the FAD of $N$. barronii is correlated to the top of Subchron C3N-2 (4.1 Ma) (Figs. 10, 12). Weaver and Gombos (1981) also place the FAD of their $N$. angulata $(=? N$. barronii) at the top of Subchron C3N-2. Ciesielski (1983) notes that the FAD of $N$. angulata $(=? N$. barronii $)$ is diachronous and ranges within Subchron $\mathrm{C} 3 \mathrm{~N}-2$ from about 4.2 to $4.1 \mathrm{Ma}$. He states however, that in most of his cores 
the FAD is at about 4.2 Ma. Despite the diachronous FAD of $N$. barronii between 4.2 and $4.1 \mathrm{Ma}$ we propose to use the species as a biostratigraphic marker because the species is easy to identify and also occurs in moderately to poorly preserved assemblages.

A distinct mass occurrence of fragments of the giant diatom Ethmodiscus rex occurs around 4.0-3.8 Ma (near Subchron C3N-1).

\section{Thalassiosira inura Partial-Range Zone}

Authors. Gersonde and Burckle, herein.

Definition of top. FAD Nitzschia barronii.

Definition of base. FAD Thalassiosira inura.

Age. 4.47-4.2 Ma.

Paleomagnetic correlation. The zone ranges in the Gilbert Chron from the base of Subchron $\mathrm{C} 3 \mathrm{~N}-3$ to approximately the middle of Subchron $\mathrm{C} 3 \mathrm{~N}-2$.

Discussion and remarks. Other species having their FAD within the T. inura Zone are Rouxia heteropolara, Thalassiosira complicata, and Nitzschia lacrima. Characteristic species occurring within the $T$. inura Zone are Nitzschia aurica and N. praeinterfrigidaria. The T. inura Zone replaces parts of the Nitzschia praeinterfrigidaria Zone of McCollum (1975), and the Nitzschia reinholdii Zones of Weaver and Gombos (1981) (Fig. 2). The latter zones lead to some confusion because the nominate species were not clearly described (N. praeinterfrigidaria), or occur only sporadically in Antarctic sediments ( $N$. reinholdii).

\section{Cosmiodiscus intersectus Partial-Range Zone}

Authors. Gersonde and Burckle, herein.

Definition of top. FAD Thalassiosira inura.

Definition of base. FAD Cosmiodiscus intersectus.

Age. late Miocene to early Pliocene, 7.9-4.47 Ma.

Paleomagnetic correlation. The zone ranges from the base of Chron $\mathrm{C} 4$ to the base of Subchron C $3 \mathrm{~N}-3$.

Discussion and remarks. Another species having its FAD near the base of the $C$. intersectus Zone is Actinocyclus ingens var. ovalis, which ranges from $\sim 7.9-7.8 \mathrm{Ma}$ up to $\sim 7.2 \mathrm{Ma}$. Nitzschia aurica, which occurs commonly to abundantly in all sediments of the $C$. intersectus Zone recovered at Holes 689B and 690B, has its first consistent occurrence at $\sim 7.9 \mathrm{Ma}$. Another important date is the FAD of Nitzschia arcula, placed at $\sim 7.8 \mathrm{Ma}$. The FAD of Thalassiosira oestrupii also falls in the $C$. intersectus Zone. However, due to a disconformity at the Miocene/Pliocene boundary this FAD could not be determined exactly. It must be at $4.9 \mathrm{Ma}$ or older, and younger than $6.3 \mathrm{Ma}$. Probably the FAD of $T$. oestrupii in the Antarctic is time-synchronous to its FAD in the low latitudes and the high and mid-latitudes of the North Pacific. There, this species first occurs at $5.1 \mathrm{Ma}$ according to the compilation of Barron (1985) (Table 2). The FAD of Nitzschia praeinterfrigidaria can tentatively be placed near Subchron $\mathrm{C} 3 \mathrm{~N}-4$. The last consistent occurrence of Denticulopsis hustedtii is in the top of the zone and its LAAD ( $>15 \%$ of total assemblage) in Holes 689B and 690B is at $\sim 7.3$ $\mathrm{Ma}$.

Other interesting species are those of the Thalassiosira torokina-majuramica group. We also note sparse occurrences of Thalassiosira usatchevii, T. miocenica, T. praeconvexa, and Nitzschia cylindrica, all ranging in the lower part of the zone (within Chron C4). Additionally we found in the latter interval three species of Hemidiscus. In the sediments of early Pliocene age (around Subchron $\mathrm{C} 3 \mathrm{~N}-4$ ) we note the consistent occurrence of Thalassiosira convexa var. aspinosa.

The relatively long time range of the $C$. intersectus Zone is due to widespread, long-ranging disconformities at the Miocene/Pliocene boundary, spanning from $\sim 4.9$ to $6.7 \mathrm{Ma}$ (Hole 689B) and 4.6 to $7.9 \mathrm{Ma}$ (Hole 690B). The C. intersectus Zone replaces the Denticulopsis hustedtii Zone of McCollum (1975). The top and base of McCollum's zone are defined by the LAD of D. hustedtii and Denticulopsis lauta, respectively. Weaver and Gombos (1981) modified the definition of the top and defined it by the LAAD of $D$. hustedtii, but without circumscribing quantitatively the term LAAD. D. lauta was recovered only sporadically in the holes of Leg 113, except in Hole 696B where it occurs in few to common numbers in Miocene sediments (Table 9). However, because of the sparse recovery at Site 696 , the range of this species could not be determined accurately. The distribution pattern of $D$. lauta suggests that the biogeographic province of the species may be more linked to the Subantarctic and northern Antarctic regions of the Southern Ocean.
This might indicate probable diachronism in the time-geographic distribution of D. lauta.

\section{Asteromphalus kennettii Partial-Range Zone}

Authors. Gersonde and Burckle, herein.

Definition of top. FAD Cosmiodiscus intersectus.

Definition of base. FAD Asteromphalus kennettii.

Age. late Miocene, 9.6-7.9 Ma.

Paleomagnetic correlation. The zone ranges from the central portion of Subchron C $5 \mathrm{~N}-1$ to the base of Chron C4.

Discussion and remarks. The first occurrence of several Hemidiscus species which range into the $C$. intersectus Zone is in the upper portion of the A. kennettii Zone. The top of an abundance interval of Actinocyclus ingens ranging from $\sim 9.8-9.7 \mathrm{Ma}$ to $8.8 \mathrm{Ma}$ falls about midway within the A. kennettii Zone. Another species which occurs few to common throughout the entire zone is $D$. hustedtii.

\section{Nitzschia praecurta Partial-Range Zone}

Authors. Gersonde and Burckle, herein.

Definition of top. FAD Asteromphalus kennettii.

Definition of base. LAD Nitzschia praecurta.

Age. latest middle Miocene to early late Miocene, 10.5-9.6 Ma.

Paleomagnetic correlation. The zone ranges from the reversed interval between Subchrons $\mathrm{C} 5 \mathrm{~N}-2$ and $\mathrm{C} 5 \mathrm{~N}-1$ to the central portion of Subchron $\mathrm{C} 5 \mathrm{~N}-1$.

Discussion and remarks. The LAD of Denticulopsis praedimorpha is near the base of the $N$. praecurta Zone, at $10.4 \mathrm{Ma}$. In the upper portion of the $N$. praecurta Zone is the top of an abundance interval of Denticulopsis dimorpha which ranges from $\sim 11.0-10.9$ Ma to $\sim 9.9-$ $9.8 \mathrm{Ma}$, followed by an abundance interval of $D$. hustedtii ranging from -9.9-9.8 Ma to about 7.3 Ma. Another date within the $N$. praecurta Zone is the base of an abundance interval of $A$. ingens, which can be placed at $\sim 9.8-9.7 \mathrm{Ma}$.

\section{Denticulopsis praedimorpha Partial-Range Zone}

Authors. Gersonde and Burckle, herein.

Definition of top. FAD Nitzschia praecurta.

Definition of base. FAD Denticulopsis praedimorpha.

Age. middle Miocene, 12.6-10.5 Ma.

Paleomagnetic correlation. The zone ranges from Subchron C5AN-4 to the reversed interval between Subchrons $\mathrm{C} 5 \mathrm{~N}-2$ and $\mathrm{C} 5 \mathrm{~N}-1$.

Discussion and remarks. The nominate species ranges into the lowermost part of the younger overlying $N$. praecurta Zone, and thus has a total range from 12.6 to $10.4 \mathrm{Ma}$. An identical range is reported for the species from the high- and mid-latitude North Pacific (Barron 1985). Between $\sim 12.5 \mathrm{Ma}$ and 10.9-10.7 Ma D. praedimorpha occurs commonly to abundantly. In the lower portion of the $D$. praedimorpha Zone is the top of an $A$. ingens abundance interval ( $>15 \%$ of total assemblage), which ranges from $\sim 14.9$ to $12.4 \mathrm{Ma}$, and the top of an abundance interval of $D$. hustedtii ( $>15 \%$ of total assemblage) spanning 14.0-12.4 Ma. An abundance interval of D. dimorpha has its base at $\sim 11.0-10.9 \mathrm{Ma}$. Another important date in the lower part of the zone is the LAD of Actinocyclus ingens var. nodus at $\sim 12.3 \mathrm{Ma}$. Additionally we note rare occurrences of Crucidenticula nicobarica, Katathiraia aspera, and Nitzschia donahuensis in the lower portion of the $D$. praedimorpha Zone.

\section{Nitzschia denticuloides Partial-Range Zone}

Authors. Weaver and Gombos (1981), redefined herein.

Definition of top. FAD Denticuloides praedimorpha.

Definition of base. FAD Nitzschia denticuloides.

Age. middle Miocene, 13.5-12.6 Ma.

Paleomagnetic correlation. The zone ranges from the reversed interval between Subchrons C5AN-7 and C5AN-6 to Subchron C5AN-4.

Discussion and remarks. The base of the $N$. denticuloides Zone coincides with the LAD of Nitzschia grossepunctata. Few to abundant species within the zone are $A$. ingens, $A$. ingens var. nodus, and $D$. hustedtii. Crucidenticula nicobarica, Katathiraia aspera, Mediaria splendida, and Nitzschia donahuensis occur rarely.

The herein defined $N$. denticuloides Zone covers a lower portion of the $N$. denticuloides Zone as defined by Weaver and Gombos (1981) (Fig. 2). The coincidence of LAD of $N$. grossepunctata with FAD of $N$. denticuloides was also described by Weaver and Gombos (1981). 


\section{Denticulopsis hustedtii/Nitzschia grossepunctata} Concurrent-Range Zone

Authors. Gersonde and Burckle, herein.

Definition of top. FAD Nitzschia denticuloides.

Definition of base. FAD Denticulopsis hustedtii.

Age. middle Miocene, 14.2-13.5 Ma.

Paleomagnetic correlation. The zone ranges from the top of Subchron C5AN-8 to the reversed interval between Subchrons C5AN-7 and C5AN-6.

Discussion and remarks. The nominate species $D$. hustedtii ranges into the early Pliocene interval of the Cosmiodiscus intersectus Zone and thus has a total range from 14.2 to $\sim 4.5 \mathrm{Ma}$. Barron (1985) reported the FAD of $D$. hustedtii at $14.3 \mathrm{Ma}$ for low latitudes and at 14.2 Ma for high to mid-latitudes of the North Pacific, which is similar to that in the Antarctic Ocean. This suggests that the FAD of $D$. hustedtii can be used as a worldwide datum plane for the early middle Miocene. The co-occurring species $N$. grossepunctata has its LAD at the top (13.5 Ma) of the zone. The base of an abundance interval of the nominate species is at $14.0 \mathrm{Ma}$ and ranges into the lower portion of the $D$. praedimorpha Zone. There are rare occurrences of Crucidenticula nicobarica and Mediaria splendida.

A D. hustedtii Zone was also defined by McCollum (1975) and later modified by Weaver and Gombos (1981). McCollum's zone has a different range compared to the herein proposed $D$. hustedtii Zone (Fig. 2). Its top was defined by the LAD, and the LAAD (Weaver and Gombos's definition), of $D$. hustedtii, and the base was placed at the LAD of $D$. lauta.

\section{Nitzschia grossepunctata Partial-Range Zone}

Authors. Weaver and Gombos (1981), redefined herein.

Definition of top. FAD Denticulopsis hustedtii.

Definition of base. FAD Nitzschia grossepunctata.

Age. early middle Miocene, 15.3-14.2 Ma.

Paleomagnetic correlation. The zone ranges from the upper portion of the lower reversed interval of Chron C5B (below Subchron C5BN-2) to the top of Subchron C5AN-8.

Discussion and remarks. The lower part (interval below Chron C5A) of the $N$. grossepunctata Zone is characterized by high abundances of Denticulopsis maccollumii. The LAD of the latter species was placed into the uppermost portion of the zone at about 14.4 Ma. Other important datums in the $N$. grossepunctata Zone are the FAD of Actinocyclus ingens, placed at $\sim 15.2 \mathrm{Ma}$, and the FAD of Actinocyclus ingens var. nodus, placed at $\sim 14.9 \mathrm{Ma}$. The last consistent occurrence of Thalassiosira spinosa is at $\sim 14.6 \mathrm{Ma}$.

Weaver and Gombos (1981) define their N. grossepunctata Zone by the LAD of Coscinodiscus lewisianus (base of zone) and the LAD of the nominate species. In the herein modified $N$. grossepunctata Zone, the last occurrences of $C$. lewisianus are in the lowermost part of the zone, somewhere between Subchrons C5BN-2 and C5BN-1 ( 15.0 Ma). The LAD of Raphidodiscus marylandicus is also noted at about the same age.

\section{Denticulopsis maccollumii Partial-Range Zone}

Author. McCollum (1975), renamed and modified herein.

Definition of top. FAD Nitzschia grossepunctata.

Definition of base. FAD Denticulopsis maccollumii.

Age. ?late early Miocene to early middle Miocene, ?(17.6-15.4)-15.3 Ma.

Paleomagnetic correlation. Due to a disconformity around the early/ middle Miocene boundary only the top of the $D$. maccollumii Zone can be calibrated directly to the geomagnetic time scale. It is placed in the upper portion of the lower reversed interval of Chron C5B (below Subchron C5BN-2). The base is somewhere between the middle of Chron C5B and the base of Chron C5C.

Discussion and remarks. The FAD of species of the Azpeitia tabularis group probably falls into the $D$. maccollumii Zone. Other interesting species are Crucidenticula kanayae, Raphidodiscus marylandicus, Synedra jouseana, Coscinodiscus lewisianus, and Thalassiosira spinosa.

McCollum (1975) defined the base of his Denticula antarctica (= Denticulopsis maccollumii) Zone by the FAD of the nominate species. The top was determined by the LAD of Coscinodiscus lewisianus. The latter species, however, occurs at Holes 689B and 690B within or below the $D$. maccollumii Zone. Thus the original definition of the top of the zone had to be redefined.

\section{Nitzschia maleinterpretaria Partial-Range Zone}

Authors. Weaver and Gombos (1981), redefined herein.

Definition of top. FAD Denticulopsis maccollumii.

Definition of base. FAD Nitzschia maleinterpretaria.

Age. early Miocene, ?20.2-?(16.6-15.4) Ma.

Paleomagnetic correlation. Because of disconformities in the lower Miocene sequences of Holes 689B and 690B, interpretation of the geomagnetic polarity is difficult. Based on radiolarian data of Abelmann (this volume) allowing comparison to preliminary stratigraphic results based on Leg 120 sequences, we placed the $N$. maleinterpretaria Zone into a time interval from the late Chron C6 (Subchron C6N) to the late Chron C5C.

Discussion and remarks. Besides the nominate species, Nitzschia pusilla, Thalassiosira fraga, and T. spinosa are prominent in the $N . m a-$ leinterpretaria Zone. Possibly $T$. fraga and $T$. spinos $a$ have their first occurrence date in the lower portion of the zone at $\sim 19.6 \mathrm{Ma}$, and 19.8 Ma, respectively. Barron (1985) reports the FAD of $T$. fraga at $\sim 19.6$ Ma for the mid- to high-latitude North Pacific, and at $19.9 \mathrm{Ma}$ for the low latitudes. These reports support our age interpretation for the early Miocene species in the Antarctic. Other species in the $N$. maleinterpretaria Zone are Coscinodiscus rhombicus, Raphidodiscus marylandicus, and Synedra jouseana. The first occurrences of Crucidenticula kanayae, Mediaria splendida, and Coscinodiscus lewisianus fall in the upper portion of the $N$. maleinterpretaria Zone.

\section{Thalassiosira spumellaroides Partial-Range Zone}

Author. Schrader (1976), redefined herein.

Definition of top. FAD Nitzschia maleinterpretaria.

Definition of base. FAD Thalassiosira spumellaroides.

Age. early Miocene, >?20.5-?20.2 Ma.

Paleomagnetic correlation. The top of the zone was placed in Subchron $\mathrm{C} 6 \mathrm{~N}$. The base of the T. spumellaroides Zone cannot be correlated to the geomagnetic time scale because of a disconformity around the Oligocene/Miocene boundary in Holes 689B and 690B.

Discussion and remarks. Occurrences of Synedra jouseana are common in the $T$. spumellaroides Zone. The first occurrence of $T$. spumellaroides in the mid- to high-latitude North Pacific and low-latitude Pacific is reported by Barron $(1983,1985)$ at $\sim 21.7 \mathrm{Ma}$.

\section{DIATOMS AT THE SITES}

\section{Site 689}

Site 689 is located near the crest of Maud Rise $\left(64^{\circ} 31.01^{\prime} \mathrm{S}\right.$, $3^{\circ} 5.99^{\prime} \mathrm{E}$ ) at a water depth of $2080 \mathrm{~m}$. It is the first site in the Antarctic zone where Cenozoic sediments were continuously recovered by high-quality coring using APC and XCB (extended core barrel) equipment. The sediment sequences at Site 689 are exclusively pelagic and more or less entirely biogenic in composition because of their position on an isolated topographic elevation. At Site 689 four holes were drilled, of which Hole 689B, which will be discussed herein, reached a penetration of $297.3 \mathrm{~m}$ and ended in upper Campanian sediments. The upper eight cores of Hole 689B contain Neogene sediments bearing, in general, common to abundant diatoms at good to moderate preservation. The topmost sediment sequence was not recovered undisturbed at Site 689 because the mud line was not obtained. Based on piston and gravity core studies carried out at the position of Site 689 and the surrounding Maud Rise area, the youngest sediment sequence consists of $\sim 3.0-3.5$-m-thick foraminiferal ooze spanning a time interval of about the last $2.2 \mathrm{Ma}$ (Gersonde et al., in prep; Gersonde and Cordes, in press). The topmost sediments recovered during drilling at Site 689 can be placed into the late early Pliocene-late Pliocene $N$. interfrigidaria/C. insignis Zone. Ranges and abundance patterns of species of biostratigraphic and paleoceanographic significance are shown in Table 3 (back pocket) and Figure 4.

We established a high resolution age-depth diagram for the Neogene of Hole 689B (Fig. 5) based on a combined and detailed stratigraphic interpretation of the diatom species ranges in Neogene sections of Holes 689B and 690B (Figs. 4, 6) and 


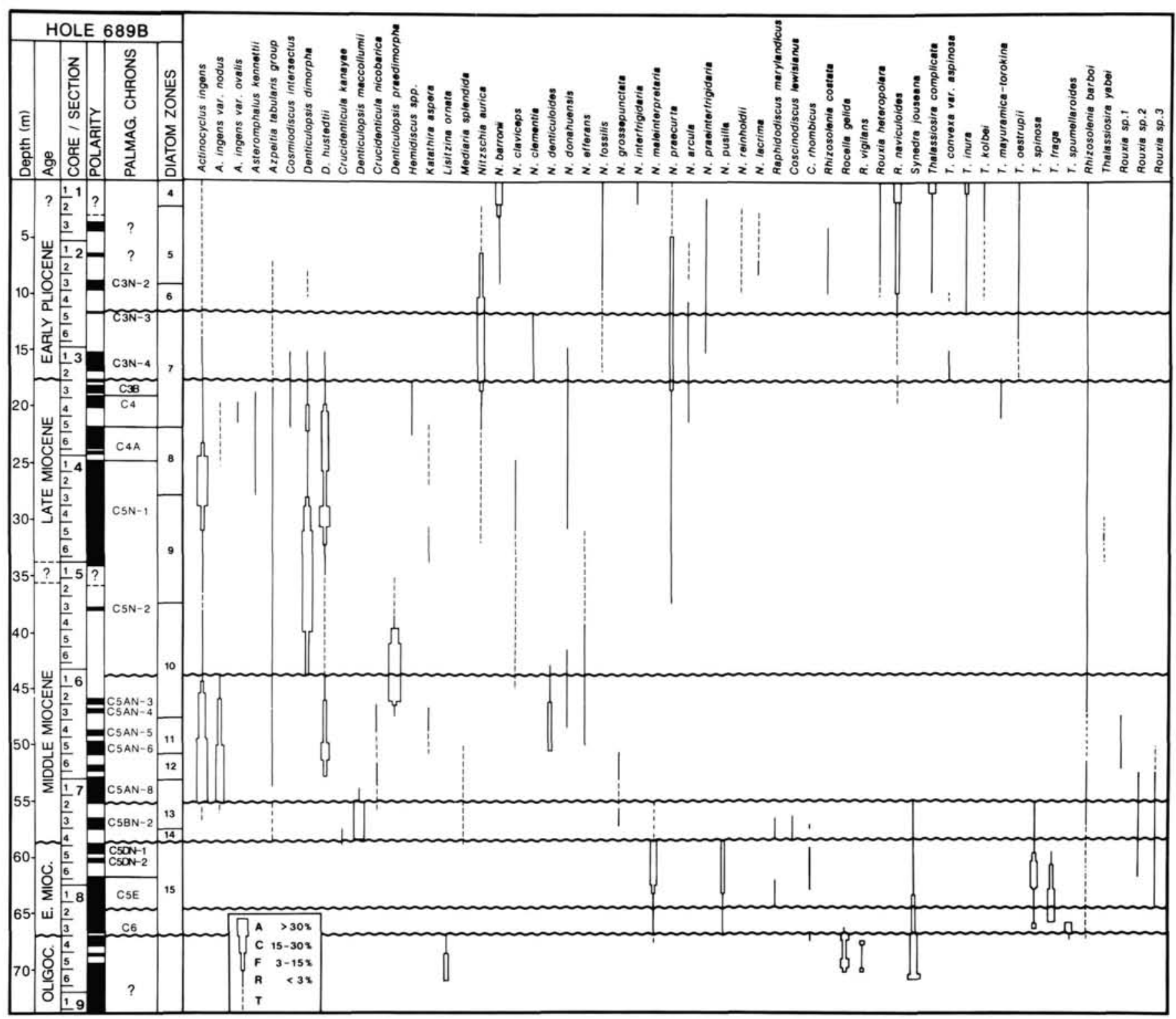

Figure 4. Ranges and abundance patterns of selected diatom species in the Neogene sections of Hole 689B and Neogene diatom zonal assignment correlated to the magnetostratigraphy of Spieß (this volume). Disconformities are indicated by wavy lines. Diatom zones are numbered as follows: (4) Nitzschia interfrigidaria/Cosmiodiscus insignis Zone; (5) Nitzschia barronii Zone; (6) Thalassiosira inura Zone; (7) Cosmiodiscus intersectus Zone; (8) Asteromphalus kennettii Zone; (9) Nitzschia praecurta Zone; (10) Denticulopsis praedimorpha Zone; (11) Nitzschia denticuloides Zone; (12) Denticulopsis hustedtii/Nitzschia grossepunctata Zone; (13) Nitzschia grossepunctata Zone; (14) Denticulopsis maccollumii Zone; (15) Nitzschia maleinterpretaria Zone.

considering the magnetostratigraphic results of Spieß (this volume) with additional radiolarian biostratigraphic data of Lazarus (this volume) and Abelmann (this volume). Seven Neogene disconformities could be determined (Table 4). The lowermost hiatus is at 67 mbsf separating the lower Miocene from the upper Oligocene and spanning from $\sim 20.0$ to $\sim 26.3 \mathrm{Ma}$. Another prominent hiatus is at $18.1 \mathrm{mbsf}$ and covers $\sim 4.9-6.3$ $\mathrm{Ma}$, thus omitting the sediments around the Miocene/Pliocene boundary. Three or probably even more hiatuses occur between 55 and $67 \mathrm{mbsf}$, which impede an accurate age assignment of this interval.

The first occurrence of $N$. interfrigidaria in Sample 113689B-1H-2, 28-29 cm, places the interval above Sample 113689B-1H-2, 50-52 cm, into the Nitzschia interfrigidaria/Cosmiodiscus insignis Zone (Table 3). Species occurrences of few to common in this zone are Nitzschia barronii, Thalassiosira complicata, T. inura, T. oestrupii, and Rouxia naviculoides. A marked increase in Ethmodiscus rex fragments occurs between Samples 113-689B-1H-3, 28-29 cm, and $-2 \mathrm{H}-2,28-29 \mathrm{~cm}$. This interval was found to be at $\sim 4.0-3.8 \mathrm{Ma}$ (near Subchron C3N-1) in Hole 690B. The base of the Nitzschia barronii Zone is placed between Samples 113-689B-2H-3, 90-92 cm, and -2H-3, 28-29 $\mathrm{cm}$, marked by the first occurrence of the nominate species. Species occurrences of few in the Nitzschia barronii Zone are Nitzschia aurica, N. praecurta, and Rouxia naviculoides. Other species found in this zone are Rhizosolenia costata, Thalassiosira complicata, T. inura, T. oestrupii, Nitzschia lacrima, and $N$. reinholdii. Between Samples 113-689B-2H-5, 27-28 cm, and $-2 \mathrm{H}-5,55-57 \mathrm{~cm}(\sim 11.7 \mathrm{mbsf})$, we assume a short-ranging hiatus which omits the lower part of the Thalassiosira inura Zone. 


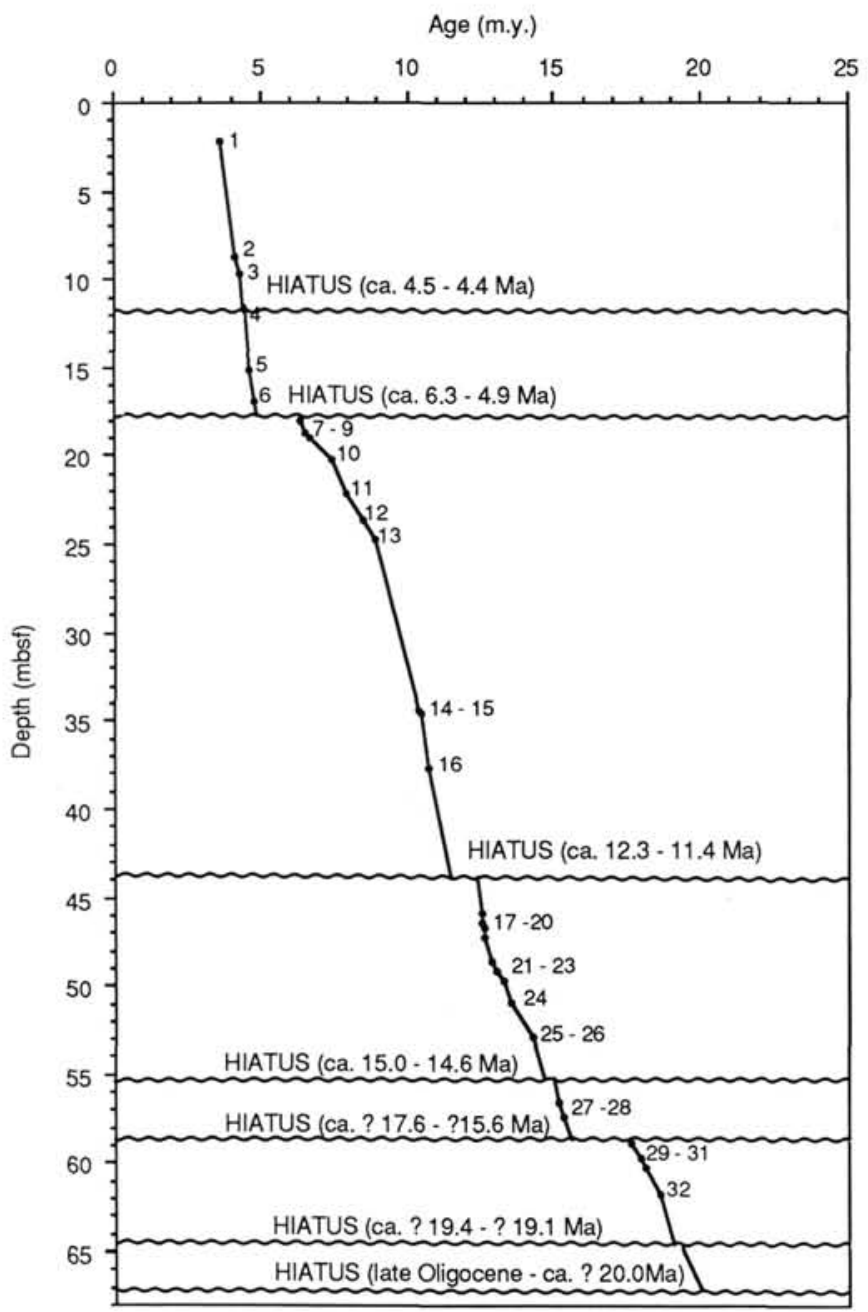

Figure 5. Age-depth diagram for the Neogene of Hole 689B. For definition of stratigraphic datum points 1-32 compare Table 4 .

Within the underlying Cosmiodiscus intersectus Zone is a hiatus between Samples 113-689B-3H-2, 148-150 cm, and -3H-3, 56-58 $\mathrm{cm}$ ( $\sim 18.1 \mathrm{mbsf})$. This hiatus spans from $\sim 6.3$ to $4.9 \mathrm{Ma}$ and can probably be related to major oceanographic events associated with a latest Miocene cooling event and glaciation in the Antarctic region. However, taxa below and above the hiatus are indicative of warmer conditions such as species of Hemidiscus, Thalassiosira miocenica, $T$. praeconvexa, T. convexa var. aspinosa, and Nitzschia cylindrica. The dominant species in the $C$. intersectus Zone is Nitzschia aurica. Another distinct occurrence is Nitzschia clementia ranging above the hiatus. The base of the $C$. intersectus Zone is placed between Samples 113-689B$3 \mathrm{H}-5,80-82 \mathrm{~cm}$, and $-3 \mathrm{H}-5,114-115 \mathrm{~cm}$. The base of the subsequent Asteromphalus kennettii Zone is between Samples 113$689 \mathrm{~B}-4 \mathrm{H}-3,31-32 \mathrm{~cm}$, and $-4 \mathrm{H}-3,114-115 \mathrm{~cm}$. The most important species occurring in this zone are Actinocyclus ingens and Denticulopsis hustedtii. Other interesting species besides the nominate species are Nitzschia donahuensis, Rouxia isopolica, Nitzschia januaria, and Katathiraia aspera. The first occurrence of the nominate species of the Nitzschia praecurta Zone is between Samples 113-689B-5H-3, 56-58 cm, and -5H-3, 145$147 \mathrm{~cm}$. There is a major abundance interval of Denticulopsis dimorpha in the $N$. praecurta Zone. Other species occurring in this zone are Nitzschia donahuensis, Nitzschia claviceps, and Nitzschia efferans. In the middle portion of the underlying Denticulopsis praedimorpha Zone falls a hiatus placed between Sam-
Table 4. Definition and depth (mbsf) of stratigraphic datum points, and age range and depth of disconformities in the Neogene of Hole 689B used to construct age/depth diagram in Figure 5 .

\begin{tabular}{|c|c|c|c|}
\hline $\begin{array}{l}\text { Datum points } \\
\text { and hiatuses }\end{array}$ & $\begin{array}{l}\text { Age } \\
\text { (Ma) }\end{array}$ & $\begin{array}{l}\text { Depth } \\
\text { (mbsf) }\end{array}$ & Definition \\
\hline 1 & 3.6 & 2.20 & FAD $N$. interfrigidaria \\
\hline 2 & 4.10 & 8.79 & Top C $3 \mathrm{~N}-2$ \\
\hline 3 & 4.24 & 9.63 & Base $\mathrm{C} 3 \mathrm{~N}-2$ \\
\hline Hiatus & ca. $4.5-4.4$ & 11.5 & \\
\hline 4 & 4.47 & 11.72 & Base $\mathrm{C} 3 \mathrm{~N}-3$ \\
\hline 5 & 4.57 & 15.17 & Top $\mathrm{C} 3 \mathrm{~N}-4$ \\
\hline 6 & 4.77 & 16.92 & Base $\mathrm{C} 3 \mathrm{~N}-4$ \\
\hline Hiatus & ca. $6.3-4.9$ & 17.8 & \\
\hline 7 & 6.37 & 18.09 & Top C3BN \\
\hline 8 & 6.50 & 18.67 & Base C3BN \\
\hline 9 & 6.70 & 18.92 & Top $\mathrm{C} 4 \mathrm{~N}-1,2,3$ \\
\hline 10 & 7.41 & 20.17 & Base $\mathrm{C} 4 \mathrm{~N}-1,2,3$ \\
\hline 11 & 7.90 & 22.18 & Top C4AN-1,2 \\
\hline 12 & 8.50 & 23.65 & Base C4AN-1,2 \\
\hline 13 & 8.92 & 24.46 & Top C5N-1 \\
\hline 14 & 10.40 & 34.4 & $\begin{array}{l}\text { LAD D. praedimor- } \\
\text { pha }\end{array}$ \\
\hline 15 & 10.42 & 34.55 & Base $\mathrm{C} 5 \mathrm{~N}-1$ \\
\hline 16 & 10.65 & 37.75 & Mid C5N-2 \\
\hline Hiatus & ca. $12.3-11.4$ & 43.8 & \\
\hline 17 & 12.46 & 45.93 & Top C5AN-3 \\
\hline 18 & 12.49 & 46.41 & Base C5AN-3 \\
\hline 19 & 12.58 & 46.68 & Top C5AN-4 \\
\hline 20 & 12.62 & 47.18 & Base C5AN-4 \\
\hline 21 & 12.83 & 48.63 & Top C5AN-5 \\
\hline 22 & 13.01 & 49.18 & Base C5AN-5 \\
\hline 23 & 13.20 & 49.68 & Top C5AN-6 \\
\hline 24 & 13.46 & 50.91 & Base C5AN-6 \\
\hline 25 & 14.20 & 52.85 & Top C5AN-8 \\
\hline 26 & 14.2 & 52.9 & FAD D. hustedtii \\
\hline Hiatus & ca. $15.0-14.6$ & 55.1 & \\
\hline 27 & 15.13 & 56.53 & Top C5BN-2 \\
\hline 28 & 15.27 & 57.40 & Base C5BN-2 \\
\hline Hiatus & $? 17.6-? 15.6$ & 58.8 & \\
\hline 29 & 17.6 & 58.8 & Top C5DN-1 \\
\hline 30 & 17.90 & 59.64 & Base C5DN-1 \\
\hline 31 & 18.13 & 60.20 & Mid C5DN-2 \\
\hline 32 & 18.56 & 61.76 & Top C5EN \\
\hline Hiatus & $? 19.4-? 19.1$ & 64.7 & \\
\hline Hiatus & I. Oligocene-?20.0 & 67.0 & \\
\hline
\end{tabular}

ples 113-689B-6H-1, 27-28 cm, and -6H-1, 74-76 cm ( $~ 43.8$ mbsf). This hiatus spans from 12.3 to $11.4 \mathrm{Ma}$. Whereas in the lower two thirds of the zone the nominate species is dominant, the upper part of the zone is characterized by high abundances of Denticulopsis dimorpha. The base of the D. praedimorpha Zone is between Samples 113-689B-6H-3, 114-115 cm, and $6 \mathrm{H}-4,28-29 \mathrm{~cm}$. The lower boundary of the subsequent Nitzschia denticuloides Zone falls between Samples 113-689B-6H-5, $114-115 \mathrm{~cm}$, and $-6 \mathrm{H}-6,28-29 \mathrm{~cm}$. Prominent species in this zone are Actinocyclus ingens and Denticulopsis hustedtii. Other species occurring within this zone are Crucidenticula nicobarica, $K$. aspera, $N$. donahuensis, and $N$. efferans. The next zone is the Denticulopsis hustedtii/Nitzschia grossepunctata Zone which has its base between Samples 113-689B-6H-7, 28-29 cm, and $-7 \mathrm{H}-1,28-29 \mathrm{~cm}$. The zone is characterized by high abundance of the nominate species and $A$. ingens. Other species in this zone are $N$. grossepunctata, C. nicobarica, M. splendida, Rouxia sp. $1, R$. sp. 2 , and $R$. sp. 3 . The underlying Nitzschia grossepunctata Zone is marked by a disconformity between Samples 113-689B$7 \mathrm{H}-2,65-67 \mathrm{~cm}$, and $-7 \mathrm{H}-2,115-116 \mathrm{~cm}$, which ranges from 15.0 to $14.6 \mathrm{Ma}$. According to the radiolarian biostratigraphic results of Abelmann (this volume), this hiatus can be placed near Sample 113-689B-7H-2, $70 \mathrm{~cm}$ (55.1 mbsf). The base of the $N$. grossepunctata Zone is between Samples 113-689B-7H-4, $28-29 \mathrm{~cm}$, and $-7 \mathrm{H}-4,86-88 \mathrm{~cm}$. The most prominent species in the lower part of this zone is Denticulopsis maccollumii, the 
nominate species of the next zone downcore. The lower portion of the D. maccollumii Zone is cut by a disconformity placed between Samples 113-689B-7H-4, 115-116 cm, and -7H-5, 28-29 $\mathrm{cm}$ ( $\sim 58.8 \mathrm{mbsf})$, spanning from $\sim 17.6$ to $15.6 \mathrm{Ma}$. Below this hiatus is the Nitzschia maleinterpretaria Zone, bound at its base by a hiatus spanning from $\sim 20.0$ to $\sim 26.3 \mathrm{Ma}$, according to Abelmann (this volume). This Miocene-Oligocene hiatus was placed between Samples 113-689B-8H-4, 28-29 cm, and $-8 \mathrm{H}-3,144-145 \mathrm{~cm}$ (67.0 mbsf). One other hiatus in the $N . m a-$ leinterpretaria Zone is in the interval between Samples 113689B-8H-2, 86-88 cm, and $-8 \mathrm{H}-2,57-59 \mathrm{~cm}$ ( $\sim 64.7 \mathrm{mbsf})$, spanning probably from 19.4 to $19.1 \mathrm{Ma}$. The disconformity omits the reversed paleomagnetic time period between Subchrons C5EN and C6N and probably parts of these subchrons. This interpretation was based on combined diatom, radiolarian (Abelmann, this volume), and magnetostratigraphic (Spieß, this volume) results. The underlying upper Oligocene sediments are characterized by poorly preserved diatom assemblages. Synedra jouseana is most prominent. Other important species are Rocella gelida, $R$. vigilans, and Lisitzina ornata.

\section{Site 690}

Site 690 is on the western flank of Maud Rise $\left(65^{\circ} 9.63^{\prime} \mathrm{S}\right.$, $1^{\circ} 12.30^{\prime} \mathrm{E}$ ) in $2914 \mathrm{~m}$ of water. Three holes were drilled at this site, of which Hole 690B, which penetrated $213.4 \mathrm{~m}$ and ended in upper Paleocene sediments, was sampled and the Neogene was investigated in detail for refinement of the Neogene diatom biostratigraphy. Ranges and abundance patterns of species of biostratigraphic and paleoceanographic significance are shown in Table 5 (back pocket) and Figure 6 . The uppermost seven cores of Hole 690B recovered Neogene sediments. In comparison to Hole 689B, the Neogene accumulation rates at Hole 690B are slightly lower, and the Neogene sediment sequence is marked by more disconformities (Fig. 7, Table 6). However, this site was extremely useful because it contains an important middle Miocene sediment interval (upper portion of Chron C5A) which is omitted at Hole 689B by a disconformity and, in contrast to Hole 689B, Quaternary sediments were also gathered (Fig. 3). Hole 690B is also important because, by comparison with Hole 689B, coherency of the biostratigraphic results were tested and the age determination of species ranges and zonal boundaries confirmed.

The sediment interval above Sample 113-690B-2H-1, 28-29 $\mathrm{cm}$, is placed in the Thalassiosira lentiginosa and Actinocyclus ingens Zones. The sediment of that topmost interval is a foraminiferal ooze containing only rare to few diatoms of moderate to poor preservation. Relatively common to abundant are Nitzschia kerguelensis and Thalassiosira lentiginosa. The last occurrence of $A$. ingens is in Sample 113-690B-1H-2, 32-34 cm. The Actinocyclus ingens Zone is separated from the underlying Thalassiosira kolbei Zone by a disconformity which can be placed between Samples 113-690B-1H-2, 32-34 cm, and -2H-1, 28-29 $\mathrm{cm}$ ( $2 \mathrm{mbsf}$ ). The hiatus falls within the lowermost portion of the $\sim 2.4$-m-thick foraminiferal ooze and spans from $\sim 2.0$ to $0.75 \mathrm{Ma}$. The base of the T. kolbei Zone is between Samples 113-690B-2H-1, 114-115 cm, and -2H-1, 28-29 cm. The underlying $N$. interfrigidaria/Cosmiodiscus insignis Zone is marked by a hiatus situated between Samples 113-690B-2H-4, 28-29 $\mathrm{cm}$, and $-2 \mathrm{H}-4,114-115 \mathrm{~cm}$ (7.2 mbsf). The occurrence of this disconformity is primarily based on the geomagnetic polarity pattern, but it is also marked by an abundance change in Nitzschia barronii. The first occurrence of $N$. interfrigidaria which marks the base of the $N$. interfrigidaria/C. insignis Zone is between Samples 113-690B-2H-5, 28-29 cm, and -2H-5, 114$115 \mathrm{~cm}$.

Below this level follows a Pliocene to early Miocene sequence which is very similar to that described for Hole 689B. For this reason we will focus the following description of Hole 690B on the depths of zonal boundaries and disconformities, and on major differences in comparison to the recoveries at Hole 689B. For general abundance changes of diatoms in the Neogene of the Maud Rise we refer to the description given in the Site 689 section. The base of the Nitzschia barronii Zone is between Samples $113-690 \mathrm{~B}-2 \mathrm{H}-7,28-29 \mathrm{~cm}$, and $-3 \mathrm{H}-1,27-28 \mathrm{~cm}$. Within this zone occurs an abundance interval of Ethmodiscus rex between Samples 113-690B-2H-6, 114-115 cm, and -2H-5, 28-29 cm. The base of the underlying Thalassiosira inura Zone is bounded by a hiatus between Samples 113-690B-3H-2, 115-116 cm, and $3 \mathrm{H}-3,73-75 \mathrm{~cm}(\sim 14.9 \mathrm{mbsf})$. The hiatus spans $\sim 4.5-4.4 \mathrm{Ma}$ and is comparable to a hiatus in Hole 689B. The base of the following $C$. intersectus Zone is omitted by a hiatus located between Samples 113-690B-3H-5, 125-127 cm, and -3H-6, 23-25 $\mathrm{cm}$ ( 18.9 mbsf; $\sim 7.9-4.6 \mathrm{Ma})$. A comparable Miocene-Pliocene hiatus recovered in Hole $689 \mathrm{~B}$ at $18.1 \mathrm{mbsf}$ has a significantly shorter range. Within the underlying $A$. kennettii Zone is a disconformity between Samples 113-690B-4H-1, 26-27 cm, and $-3 \mathrm{H}-7,23-25 \mathrm{~cm}(\sim 21.0 \mathrm{mbsf})$. The base of the latter zone is between Samples 113-690B-4H-2, $115-116 \mathrm{~cm}$, and $-4 \mathrm{H}-3$, $26-27 \mathrm{~cm}$. The first occurrence of Nitzschia praecurta places the base of the $N$. praecurta Zone between Samples 113-690B-4H-5, $26-27 \mathrm{~cm}$, and $-4 \mathrm{H}-4,115-116 \mathrm{~cm}$. The underlying Denticulopsis praedimorpha Zone has a hiatus between Samples 113-690B$5 \mathrm{H}-6,28-29 \mathrm{~cm}$, and $-5 \mathrm{H}-6,115-116 \mathrm{~cm}$ (31.2 mbsf), which spans $\sim 11.4-11.0 \mathrm{Ma}$. Below the hiatus is a sediment sequence corresponding to the paleomagnetic Subchrons C5AN-1 and C5AN-2 in the upper portion of Chron C5A, which in Hole $689 \mathrm{~B}$ is not present due to a disconformity. This interval is characterized by high abundances of $D$. praedimorpha and also contains the FAD of Denticulopsis dimorpha located between Samples $113-690 \mathrm{~B}-5 \mathrm{H}-3,115-116 \mathrm{~cm}$, and $-5 \mathrm{H}-4,28-29 \mathrm{~cm}$, dated to be $\sim 12.4 \mathrm{Ma}$. The lower boundary of the $D$. praedimorpha Zone is between Samples 113-690B-5H-4, 28-29 cm, and -5H-5, $28-29 \mathrm{~cm}$. The lower portion of the underlying Nitzschia denticuloides Zone is cut by a disconformity between Samples 113$690 \mathrm{~B}-5 \mathrm{H}-6,28-29 \mathrm{~cm}$, and $-5 \mathrm{H}-6,115-115 \mathrm{~cm}$ (39.0 mbsf), which spans from $\sim 13.8$ to $12.8 \mathrm{Ma}$. The same hiatus omits the upper portion of the underlying Denticulopsis hustedtii/Nitzschia grossepunctata Zone, which has its base between Samples 113-690B-5H-7, 27-28 cm, and -6H-1, 28-29 cm. The lower portion of the following Nitzschia grossepunctata Zone is cut by a hiatus placed between Samples 113-690B-6H-3, 27-28 cm, and $-6 \mathrm{H}-2,114-115 \mathrm{~cm}(43.8 \mathrm{mbsf})$, which is interpreted to span ?17.6-15.1 Ma. This hiatus is also marked as a sharp facies boundary between calcareous nannofossil-bearing sediments below the hiatus and diatom ooze above the hiatus. Below the hiatus, which omits the entire Denticulopsis maccollumii Zone, follows directly the Nitzschia maleinterpretaria Zone. Two disconformities, occurring at $47.1 \mathrm{mbsf}$, and $48.7 \mathrm{mbsf}$, respectively, were placed into this zone based on combined diatom, radiolarian (Abelmann, this volume), and magnetostratigraphic (Spieß, this volume) results (Fig. 7, Table 6). The N. maleinterpretaria Zone is underlain by the Thalassiosira spumellaroides Zone between Samples 113-690B-7H-1, 28-29 cm, and $7 \mathrm{H}-1,49-51 \mathrm{~cm}$. The latter zone is characterized by abundant occurrences of Synedra jouseana and the presence of Rocella vigilans, $R$. gelida, and large diatom fragments which can be attributed to the genus Ethmodiscus. The preservation of the diatoms is poor. Only the topmost portion of the T. spumellaroides Zone is present because it is cut by a hiatus (between Samples $113-690 \mathrm{~B}-7 \mathrm{H}-1,49-51 \mathrm{~cm}$, and $-7 \mathrm{H}-1,114-115 \mathrm{~cm}, 51.2 \mathrm{mbsf}$ ). According to the radiolarian biostratigraphic results (Abelmann, this volume) and the magnetostratigraphy (Spieß, this volume), this hiatus spans from $\sim 20.5$ to $27.0 \mathrm{Ma}$. 


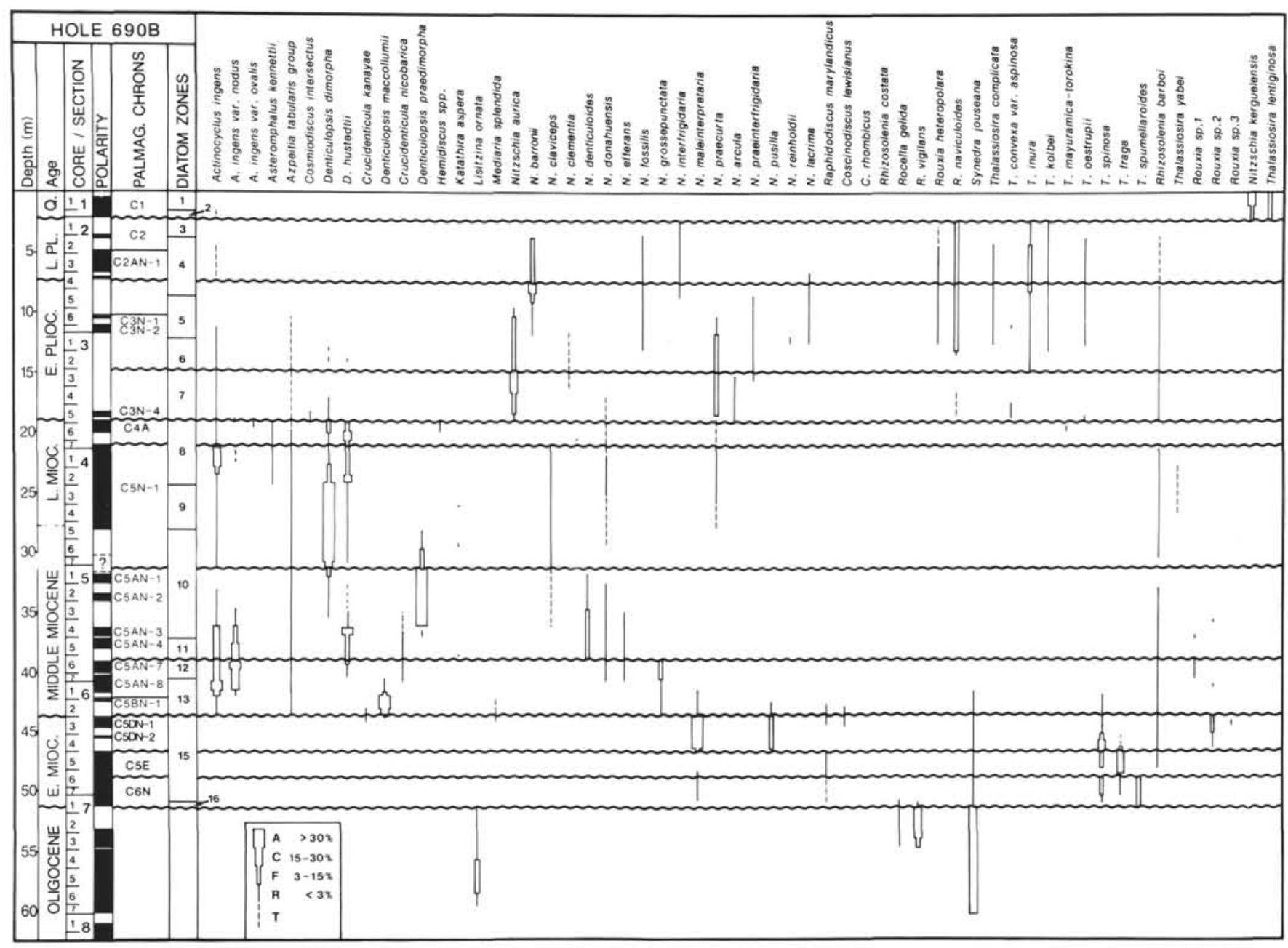

Figure 6. Ranges and abundance patterns of selected diatom species in the Neogene sections of Hole 690B and Neogene diatom zonal assignment correlated to the magnetostratigraphy of Spieß (this volume). Disconformities are indicated by wavy lines. Diatom zones are numbered as follows: (1) Thalassiosira lentiginosa Zone; (2) Actinocyclus ingens Zone; (3) Thalassiosira kolbei Zone; (4) Nitzschia interfrigidaria/Cosmiodiscus insignis Zone; (5) Nitzschia barronii Zone; (6) Thalassiosira inura Zone; (7) Cosmiodiscus intersectus Zone; (8) Asteromphalus kennettii Zone; (9) Nitzschia praecurta Zone; (10) Denticulopsis praedimorpha Zone; (11) Nitzschia denticuloides Zone; (12) Denticulopsis hustedtii/Nitzschia grossepunctata Zone; (13) Nitzschia grossepunctata Zone; (14) Denticulopsis maccollumii Zone; (15) Nitzschia maleinterpretaria Zone; (16) Thalassiosira spumellaroides Zone.

The underlying upper Oligocene sediments are characterized by poorly preserved diatom assemblages. The most prominent species is Synedra jouseana. Other important species are Rocella gelida, $R$. vigilans, and Lisitzina ornata.

\section{Site 693}

Site 693 is located on a midslope bench on the Weddell Sea margin of East Antarctica $\left(70^{\circ} 49.9^{\prime} \mathrm{S}, 14^{\circ} 34.4^{\prime} \mathrm{W}\right), 10 \mathrm{~km}$ southwest of the rim of Wegener Canyon, in $2359 \mathrm{~m}$ of water (Fig. 1). Two holes were drilled at Site 693. Hole 693A sampled a $\sim 300-$ 310 -m-thick Neogene sediment sequence. Because of rotary drilling this sequence is not well recovered, and the cores are affected by drilling disturbances and downhole contamination. A well established paleomagnetic stratigraphy could not be worked out for this hole. The same is true for Hole 693B, which was washed down to upper Miocene sediments at 234 mbsf and continued by using the XCB coring system.

In general, diatoms are widespread in the Neogene sequences of Site 693 and thus allow a biostratigraphic age assignment for the recovered sequences (Fig. 8, Table 7). Within the Quaternary, diatoms occur only in the time interval represented by the Tha- lassiosira lentiginosa Zone. The lower Quaternary and upper Pliocene sediment sequences are barren in diatoms or contain only poorly preserved assemblages. Based on the occurrence of the nominate species we place the Nitzschia interfrigidaria/Cosmiodiscus insignis Zone between Sample 113-693A-6R-5, 20-21 $\mathrm{cm}$, and Section 113-693A-4R-CC. The underlying lower Pliocene sequences are strongly expanded and consist of diatom clayey or diatom silty mud. The FAD of Nitzschia barronii is between Samples 113-693A-8R-1, 19-20 cm, and -7R-2, 20-21 cm. The base of the underlying Thalassiosira inura Zone is tentative because of the scattered occurrence of the nominate species. It is placed between Samples 113-693A-11R-3, 20-21 cm, and $-10 \mathrm{R}-6,20-21 \mathrm{~cm}$, based on the FAD of Thalassiosira complicata and the last occurrence of Denticulopsis hustedtii. Diatom abundance and preservation range from common/moderate to rare/poor in the Cosmiodiscus intersectus Zone, which straddles the Miocene/Pliocene boundary. Based on diatom biostratigraphic zonation, the position of the Miocene/Pliocene boundary in Hole 693A cannot be determined accurately. Considering the first occurrence of Thalassiosira oestrupii, a species which had its FAD around $5 \mathrm{Ma}$ (Table 2), and the LAAD of 


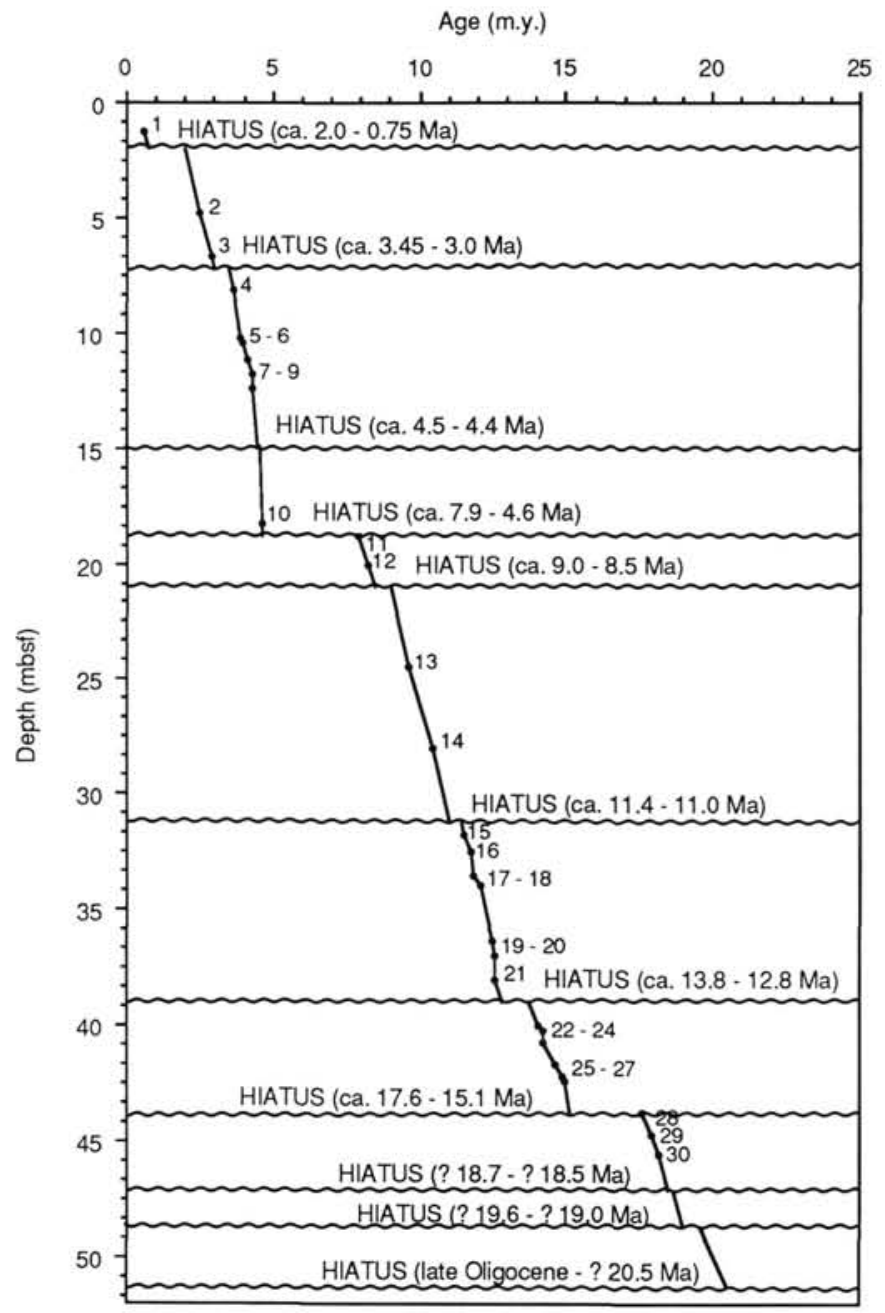

Figure 7. Age-depth diagram for the Neogene of Hole 690B. For definition of stratigraphic datum points 1-30 compare Table 6 .

Denticulopsis hustedtii, which lived in the late Miocene, the Miocene/Pliocene boundary can tentatively be placed between Sections 113-693A-17R-CC and -14R-CC. The base of the $C$. intersectus Zone is between Section 113-693A-22R-CC and Sample 113-693A-22R-2, $10-11 \mathrm{~cm}$. The boundary between the Asteromphalus kennettii and Nitzschia praecurta Zones is defined based on the abundance pattern of $D$. dimorpha, D. hustedtii, and $A$. ingens and placed between Samples 113-693A-26R-5, $20-21 \mathrm{~cm}$, and $-26 \mathrm{R}-4,20-21 \mathrm{~cm}$. Only trace and strongly fragmented A. kennettii was encountered in Hole 693A. The base of the Nitzschia praecurta Zone is between Sample 113-693A-28R4, 20-21 cm, and Section 113-693A-28R-CC. Most of the middle Miocene and some upper lower Miocene is omitted by a disconformity, which can be placed between Section 113-693A28R-CC and Sample 113-693A-29R-1, 20-21 cm ( $263 \mathrm{mbsf})$. Below the hiatus, which separates the top of the Denticulopsis praedimorpha and Nitzschia maleinterpretaria Zones, diatom preservation is moderate to poor, but successively deteriorates with increasing depth (compare Hole 693B, Table 7). For this reason the placement of the Oligocene/Miocene boundary at Site 693 can be estimated only on the basis of silicoflagellate and radiolarian data (compare Gersonde et al., this volume). The last Oligocene silicoflagellates attributed to the Dictyocha frenguelli Zone were recorded in Sample 113-693A-33R-1, 96-98 $\mathrm{cm}(\sim 302.5 \mathrm{mbsf})$, while the first unquestionable Miocene radi-
Table 6. Definition and depth (mbsf) of stratigraphic datum points, and age range and depth of disconformities in the Neogene of Hole 690B used to construct age/depth diagram in Figure 7.

\begin{tabular}{|c|c|c|c|}
\hline $\begin{array}{l}\text { Datum points } \\
\text { and hiatuses }\end{array}$ & $\begin{array}{l}\text { Age } \\
(\mathrm{Ma})\end{array}$ & $\begin{array}{l}\text { Depth } \\
\text { (mbsf) }\end{array}$ & Definition \\
\hline 1 & 0.6 & 1.3 & LAD $A$. ingens \\
\hline Hiatus & ca. $2.0-0.75$ & 2.0 & \\
\hline 2 & 2.47 & 4.83 & Top C2AN-1 \\
\hline 3 & 2.90 & 6.71 & Base C2AN-1 \\
\hline Hiatus & ca. $3.45-3.0$ & 7.2 & \\
\hline 4 & 3.6 & 8.1 & FAD $N$. interfrigidaria \\
\hline 5 & 3.88 & 10.23 & Top C3N-1 \\
\hline 6 & 3.97 & 10.48 & Base $\mathrm{C} 3 \mathrm{~N}-1$ \\
\hline 7 & 4.10 & 11.21 & Top C $3 \mathrm{~N}-2$ \\
\hline 8 & 4.24 & 11.78 & Base $\mathrm{C} 3 \mathrm{~N}-2$ \\
\hline 9 & 4.3 & 12.4 & FAD $R$. het./T. compl.* \\
\hline Hiatus & ca. $4.5-4.4$ & 14.9 & \\
\hline 10 & 4.57 & 18.23 & Top C $3 \mathrm{~N}-4$ \\
\hline Hiatus & ca. $7.9-4.6$ & 18.8 & \\
\hline 11 & 7.9 & 18.83 & Top C4AN-2 \\
\hline 12 & 8.21 & 20.07 & Base C4AN-2 \\
\hline Hiatus & ca. $9.0-8.5$ & 21.0 & \\
\hline 13 & 9.6 & 24.4 & FAD $A$. kennettii \\
\hline 14 & 10.42 & 28.03 & Base $\mathrm{C} 5 \mathrm{~N}-1$ \\
\hline Hiatus & ca. $11.4-11.0$ & 31.2 & \\
\hline 15 & 11.55 & 31.72 & Top C5AN-1 \\
\hline 16 & 11.73 & 32.45 & Base C5AN-1 \\
\hline 17 & 11.86 & 33.47 & Top C5AN-2 \\
\hline 18 & 12.12 & 33.95 & Base C5AN-2 \\
\hline 19 & 12.46 & 36.35 & Top C5AN-3 \\
\hline 20 & 12.6 & 37.0 & FAD D. praedimorpha \\
\hline 21 & 12.62 & 37.97 & Base C5AN-4 \\
\hline Hiatus & ca. $13.8-12.8$ & 39.0 & \\
\hline 22 & 14.08 & 39.95 & Base C5AN-7 \\
\hline 23 & 14.20 & 40.20 & Top C5AN-8 \\
\hline 24 & 14.2 & 40.7 & FAD D. hustedtii \\
\hline 25 & 14.66 & 41.68 & Base C5AN-8 \\
\hline 26 & 14.87 & 42.16 & Top C5BN-1 \\
\hline 27 & 14.96 & 42.41 & Base C5BN-1 \\
\hline Hiatus & ca. $17.6-15.1$ & 43.7 & \\
\hline 28 & 17.57 & 43.7 & Top C5DN-1 \\
\hline 29 & 17.90 & 44.68 & Base C5DN-1 \\
\hline 30 & 18.14 & 45.55 & Mid C5DN-2 \\
\hline Hiatus & $? 18.7-? 18.5$ & 47.1 & \\
\hline Hiatus & $? 19.6-? 19.0$ & 48.7 & \\
\hline Hiatus & 1. Oligocene-?20.5 & 51.2 & \\
\hline
\end{tabular}

* = first consistent occurrence.

olarians were reported from Section 113-693B-8X-CC $(\sim 292$ mbsf).

\section{Site 694}

Site 694 is in the northern part of the Weddell Sea abyssal plain $\left(66^{\circ} 50.8^{\prime} \mathrm{S}, 33^{\circ} 26.8^{\prime} \mathrm{W}\right)$ in a water depth of $4653 \mathrm{~m}$ (Fig. 1). The site is the deepest of seven that form a depth transect in the Weddell Sea region. Four holes were drilled at Site 694.

Hole 694A was abandoned after recovery of the first core because the sediment/water interface was not sampled. The base of this 9.8-m-long core is in a sediment interval rich in diatoms, which can be assigned to the late early Pliocene Nitzschia barronii Zone. In Hole 694B the latter interval was recovered around 13 mbsf. The recovery in Hole 694B, which was abandoned in upper Miocene sediments at 179 mbsf, was continuous only in the topmost three cores. Below that, recovery dropped considerably because of the occurrence of medium- to coarse-grained sands, between $\sim 21$ and 111.5 mbsf (Cores 113-694B-5H to $-14 \mathrm{H})$. All Pliocene and Pleistocene sediments above this sandy interval were barren in diatoms except for the diatomaceous interval at $\sim 13$ mbsf described above. Below the sandy interval, sediments bearing moderately preserved siliceous microfossils were recovered in Core 113-694B-14H. The composition of the siliceous microfossil assemblages indicates an age near the Mio- 


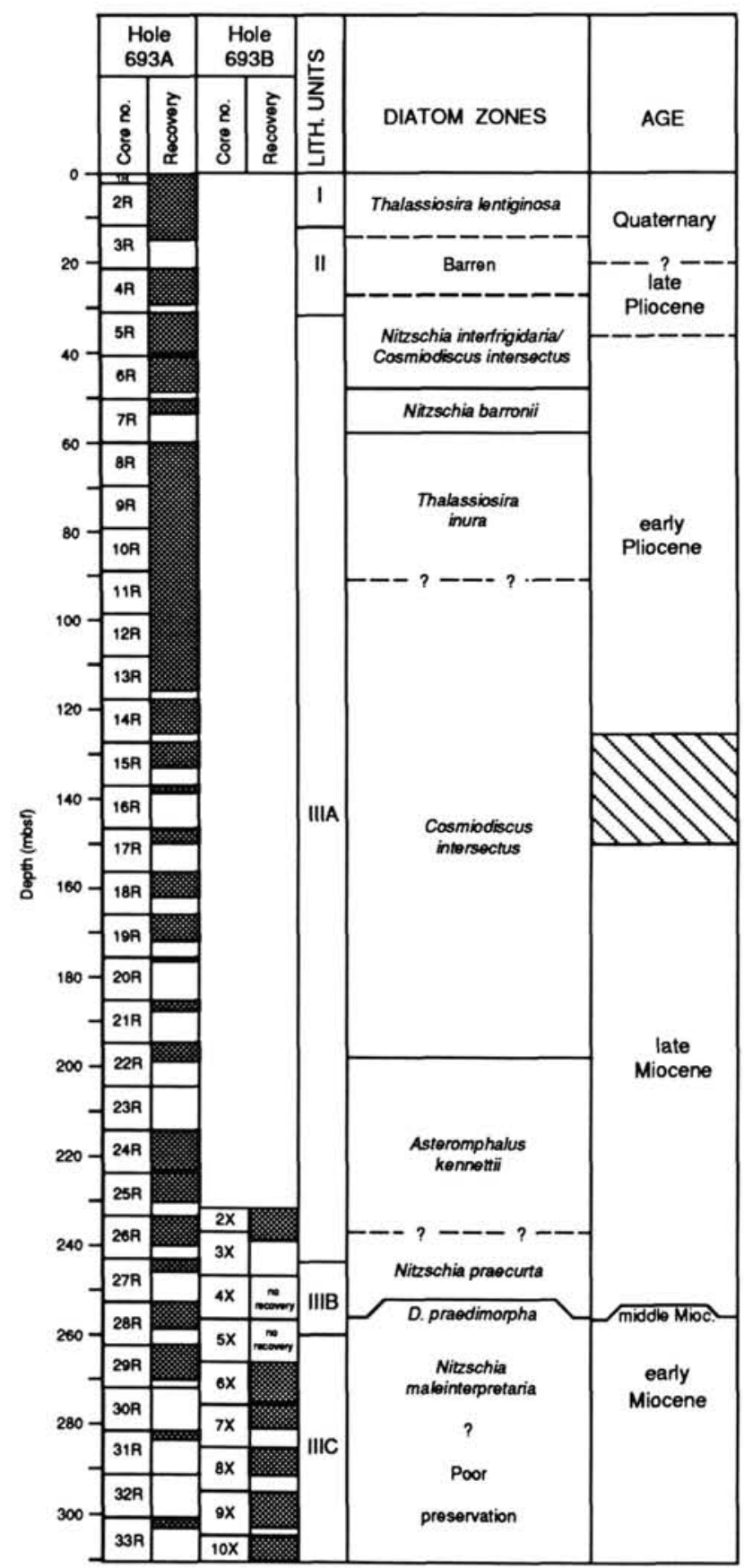

Figure 8. Diatom biostratigraphy of Holes 693A and 693B.

cene/Pliocene boundary (compare Gersonde et al., this volume). Below that level most samples are barren of diatoms or contain only poorly preserved assemblages. In Core 113-694B$24 \mathrm{X}$, the diatom Denticulopsis dimorpha occurs commonly to abundantly (Fig. 9). At the sites drilled on Maud Rise a D. dimorpha acme was observed around the middle/upper Miocene boundary (upper Denticulopsis praedimorpha-Nitzschia praecurta Zone).

Hole 694C was washed down to the total depth of Hole 694B and continued below this depth with the XCB. The recovery from Hole $694 \mathrm{C}$, which reached $391 \mathrm{mbsf}$, is low. Low recovery and poor preservation of siliceous microfossils do not allow a well established biostratigraphic age assignment for the recovered sequences. Based on scattered occurrences of diatom bio- stratigraphic marker species most of the sediments drilled in Hole $694 \mathrm{C}$ can be placed in the middle Miocene Nitzschia denticuloides and Denticulopsis hustedtii/Nitzschia grossepunctata Zones (Fig. 9).

\section{Site 695}

Site 695 is located on the southeast margin of the South Orkney microcontinent $(\mathrm{SOM})$ in the northeast Weddell Sea $\left(62^{\circ} 23.5^{\prime} \mathrm{S}\right.$, $43^{\circ} 27.1^{\prime} \mathrm{W}$ ) at $1300 \mathrm{~m}$ water depth (Fig. 1). One hole was drilled at this site using the APC and XCB coring technique, and a 341m-thick Quaternary to upper Miocene sequence was sampled consisting of predominantly diatom silty and clayey mud. The preservation of diatom assemblages is generally moderate to good, except in the lowermost portion of the hole (below Core $113-695 \mathrm{~A}-36 \mathrm{X})$ where the preservation is poor. Core recovery and preservation of cores range from good to moderate, allowing dense and more or less continuous sampling for biostratigraphic and paleomagnetic studies. However, in this study we mostly use core catcher samples for the biostratigraphic interpretation. A more comprehensive diatom biostratigraphic study of this site, which contains a well recovered and very expanded lower Pliocene sediment sequence, is in preparation. Paleomagnetic data are provided by Hamilton and O'Brien (unpubl. data; also compare Gersonde et al., this volume).

At Site 695 the Pleistocene and uppermost Pliocene T. lentiginosa, $A$. ingens, and $T$. kolbei Zones are strongly condensed (Fig. 10, Table 8). Preservation of siliceous microfossils is generally poor in this sediment sequence. Disconformities probably occur in the uppermost Pliocene and Quaternary, but sample spacing was not close enough to delineate them clearly. The sedimentation rate increases gradually from the Pleistocene to the upper Pliocene. In the upper Pliocene the diatoms exhibit a marked increase in diversity and preservation. The Nitzschia interfrigidaria/Cosmiodiscus insignis Zone is placed between Sections 113-695A-7H-CC and -1H-CC. A dramatic increase of the sedimentation rate occurred in the late early Pliocene, so that the lower Pliocene Nitzschia barronii and Thalassiosira inura Zones, which are short ranging zones, are drastically expanded. The base of the Nitzschia barronii Zone is between Sections $113-695 \mathrm{~A}-16 \mathrm{H}-\mathrm{CC}$ and $-15 \mathrm{H}-\mathrm{CC}$, and the base of the underlying Thalassiosira inura Zone falls into the interval between Sections 113-695A-25X-CC and -23X-CC. On the basis of radiolarian biostratigraphic data and physical-properties logs, a Miocene-Pliocene hiatus is suggested at the base of Hole 695A (see Gersonde et al., this volume). This hiatus is probably located at $315 \mathrm{mbsf}$ and ranges from $\sim 8$ to $\sim 5 \mathrm{Ma}$ (Fig. 10). The range of the hiatus cannot be determined accurately because of the poor preservation of siliceous microfossils in the four lowermost cores of Hole 695A.

\section{Site 696}

Site 696 lies on the southeast margin of the South Orkney microcontinent (SOM), in $650 \mathrm{~m}$ of water at $61^{\circ} 50.9^{\prime} \mathrm{S}, 42^{\circ} 56^{\prime} \mathrm{W}$ (Fig. 1). Two holes were drilled at Site 696. Hole 696A, which has its base in lower Pliocene sediments (Cosmiodiscus intersectus Zone) at 103 mbsf, includes $10 \mathrm{APC}$ and $2 \mathrm{XCB}$ cores. Hole 696B was washed to $76.6 \mathrm{mbsf}$ and continued by rotary drilling. The deepest datable Neogene sediments were sampled in Core $113-696 \mathrm{~B}-50 \mathrm{R}$ at $\sim 530 \mathrm{mbsf}$ and placed in the lower middle Miocene Nitzschia grossepunctata Zone. An accurate biostratigraphic age assignment is not possible because of poor recovery.

Compared to Site 695 , the Pleistocene and upper Pliocene section at Site 696 is strongly condensed (Fig. 11, Table 9). Sediments of the early Pliocene Nitzschia barronii and early/late Pliocene Nitzschia interfrigidaria/Cosmiodiscus insignis Zone are omitted by a hiatus or strongly condensed. The top of the Thalassiosira inura Zone is placed between Sample 113-696A- 
Table 7. Stratigraphic occurrences of selected diatom species from the Neogene of Holes 693A and 693B. Abbreviations are explained in Table 3.

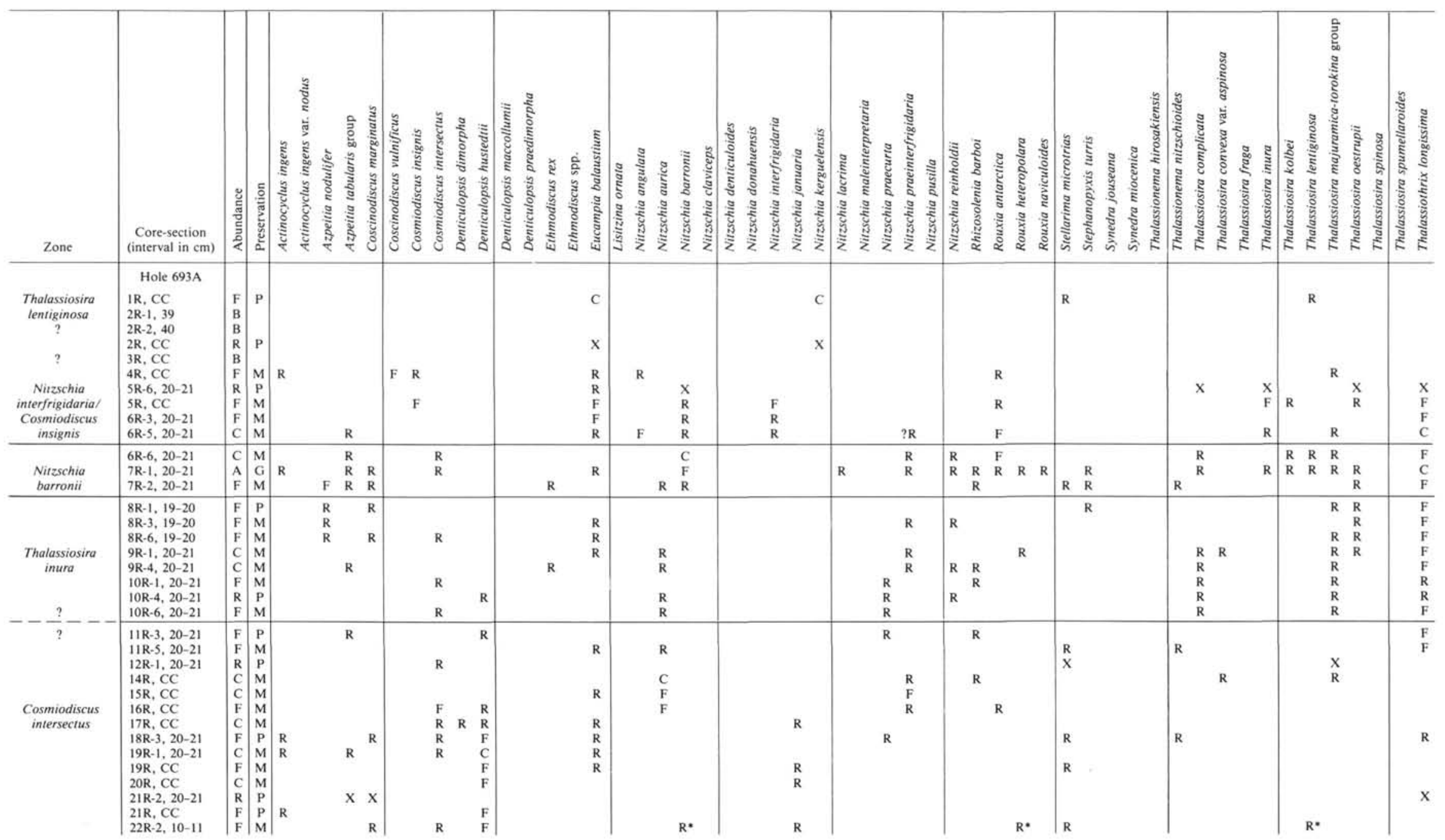




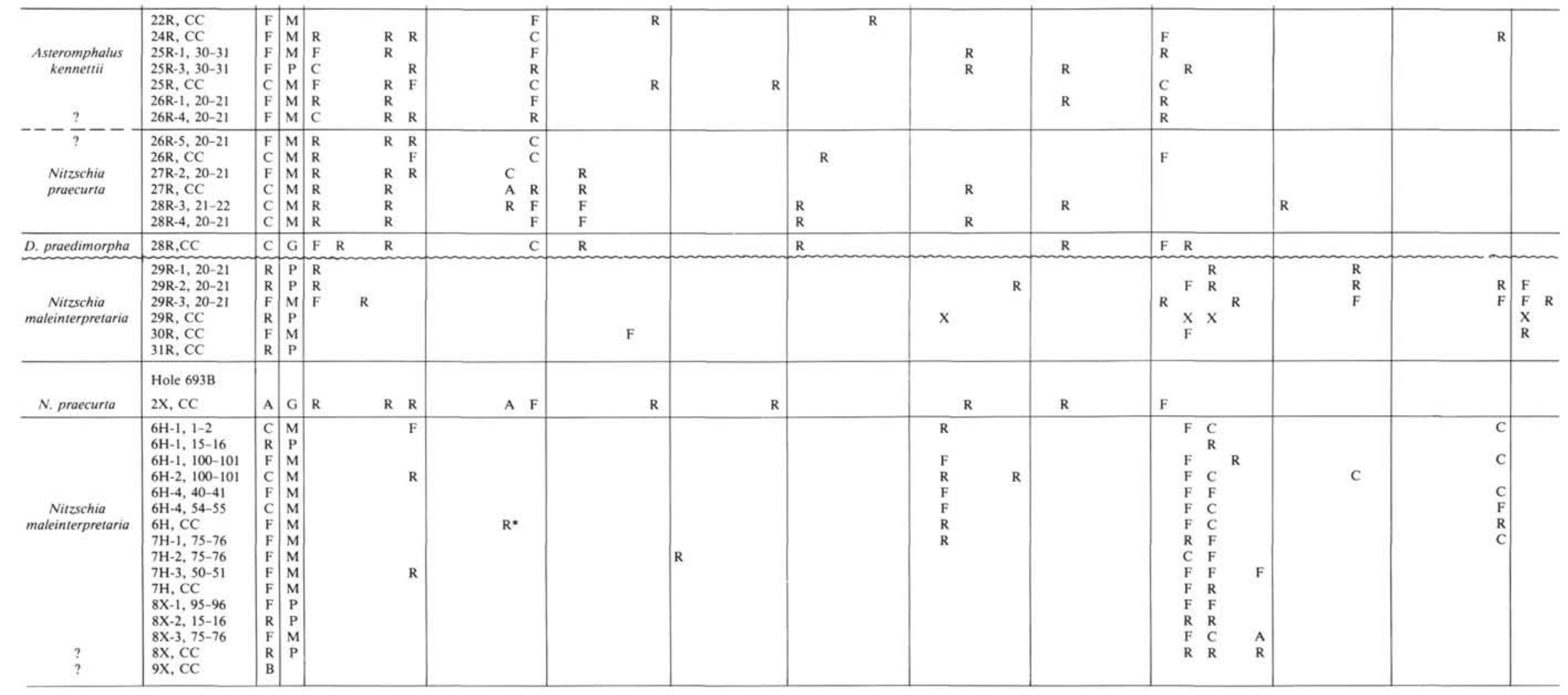




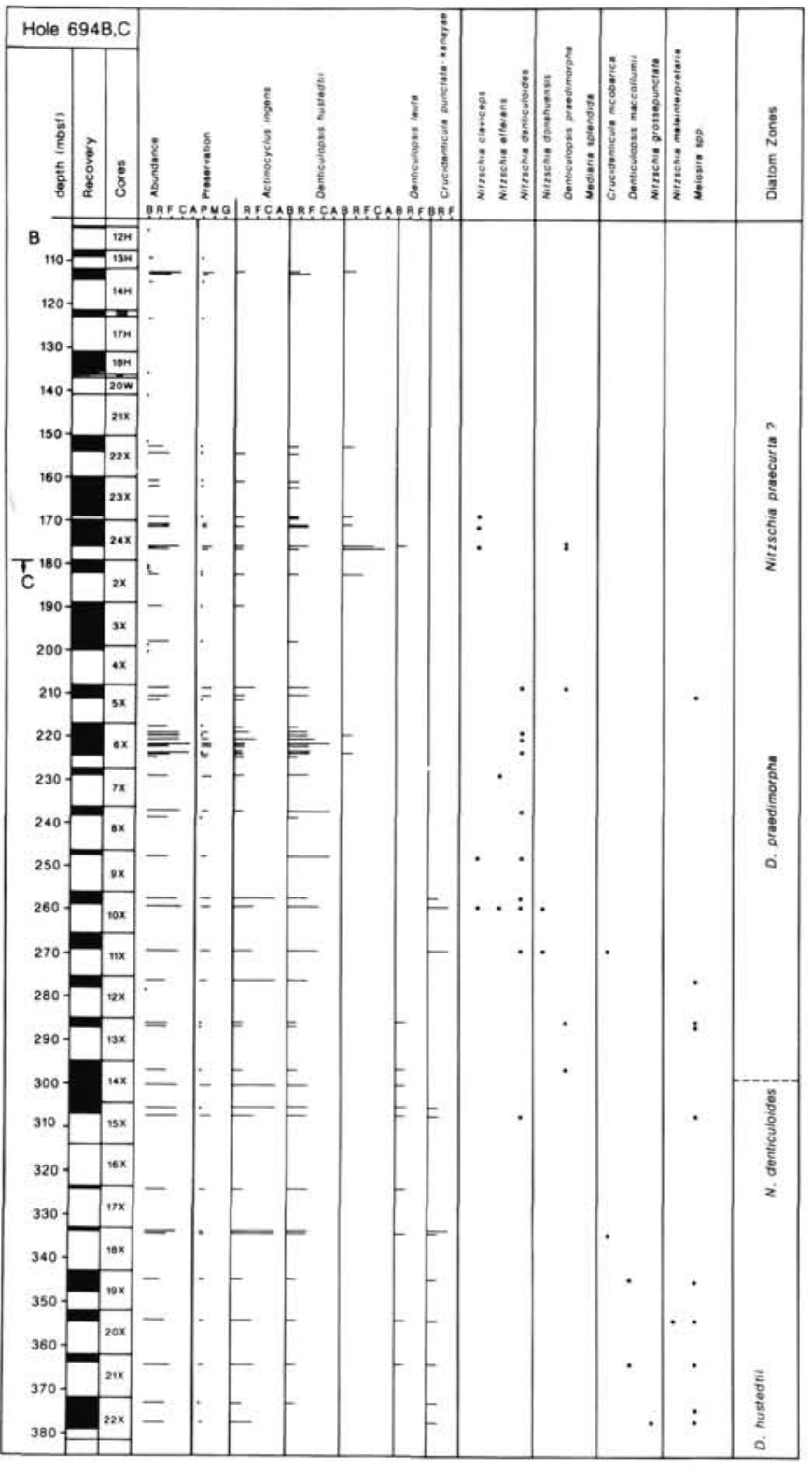

Figure 9. Relative abundance and range of selected diatom species, and inferred diatom biostratigraphy of Holes 694B and 694C (below 100 mbsf). Abundance: $\mathrm{A}=$ abundant, $\mathrm{C}=$ common, $\mathrm{F}=$ few, $\mathrm{R}=$ rare; dots indicate rare occurrence. Preservation: $\mathrm{G}=\operatorname{good}, \mathrm{M}=$ moderate, $\mathrm{P}=$ poor.

$3 \mathrm{H}-1,50-51 \mathrm{~cm}$, and Section 113-696A-2 H-CC and its base between Section 113-696A-6H-CC and Sample 113-696A-6H-4, $120-121 \mathrm{~cm}$. The sediment interval expected to include the Miocene/Pliocene boundary was not recovered.

The sampled Miocene is rich in diatoms. However, because of low recovery and problems with downhole contamination the stratigraphic age assignment can only be tentative. The boundary between the Nitzschia praecurta and Denticulopsis praedimorpha Zones, which is close to the middle/upper Miocene boundary, is between Sections 113-696B-26R-CC and -25R-CC, at $\sim 290$ mbsf. Below Core 113-696B-50R (early middle Miocene $N$. grossepunctata Zone) no datable Neogene samples were obtained. Site 696 is the only Leg 113 site where we found few to common Denticulopsis lauta. This suggests that the biogeo-

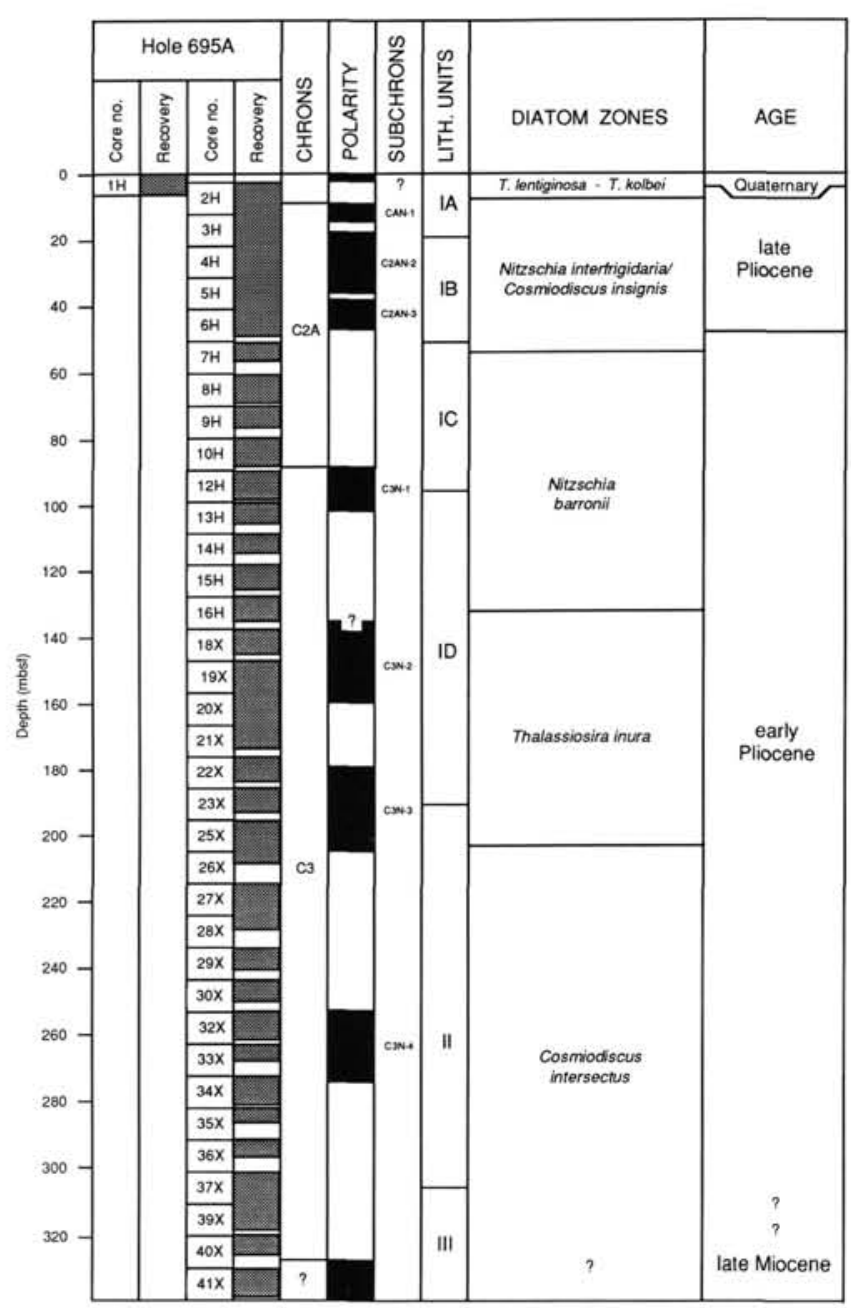

Figure 10. Diatom biostratigraphy of Hole 695A. A tentative Miocene/ Pliocene disconformity is indicated by a wavy line. Paleomagnetic data according to Hamilton and O'Brien (unpubl. data, also compare Gersonde et al., this volume).

graphic province of the species may be more linked to the Subantarctic and northern Antarctic regions of the Southern Ocean.

\section{Site 697}

Site 697 lies in the Jane Basin $\left(61^{\circ} 48.6^{\prime} \mathrm{S}, 40^{\circ} 17.3^{\prime} \mathrm{W}\right)$ in $3480 \mathrm{~m}$ of water, and is the deepest of the three-site transect on the southeast margin of the South Orkney microcontinent (SOM) in the northeast Weddell Sea (Fig. 1). Two holes were drilled at Site 696. Hole 697A recovered $26.6 \mathrm{~m}$ of sediments of late Quaternary age in three APC cores and was then abandoned for technical reasons. Hole 697B was washed to $18 \mathrm{mbsf}$ and cored to 322.9 mbsf using APC and XCB methods. In this hole a Quaternary to lower Pliocene sediment sequence was sampled. Core recovery varies from good to moderate in the Quaternary through the upper Pliocene, and from moderate to poor in the lower Pliocene. The recovered sediment sequences allowed the establishment of a magnetostratigraphic record useful for the calibration of Pliocene-Pleistocene biostratigraphic zonations (Hamilton and O'Brien, unpubl. data, compare Gersonde et al., this volume). However, the abundance and preservation of diatoms exhibit strong fluctuations, thus some species ranges and zonal boundaries cannot be determined accurately (Fig. 12, Table 10). 
Table 8. Stratigraphic occurrences of selected diatom species from Hole 695A. Abbreviations are explained in Table 3.

\begin{tabular}{|c|c|c|c|c|c|c|c|c|c|c|c|c|c|c|c|c|c|c|c|c|c|c|c|c|}
\hline Zone & $\begin{array}{c}\text { Hole 695A } \\
\text { Core-section } \\
\text { (interval in cm) }\end{array}$ & 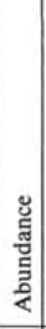 & 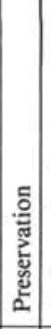 & 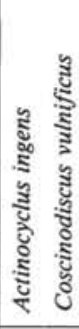 & 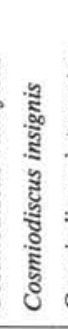 & 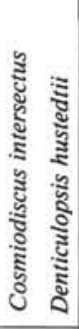 & 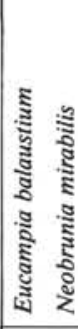 & 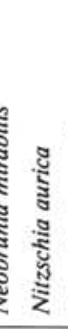 & 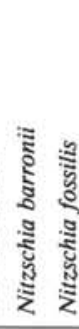 & 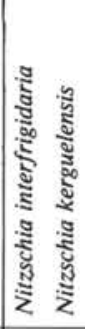 & 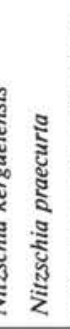 & 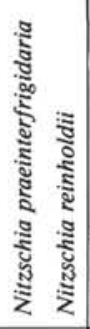 & 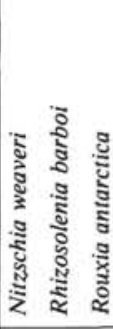 & 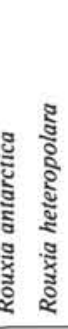 & 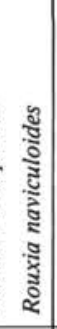 & 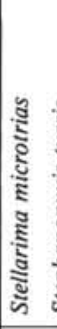 & 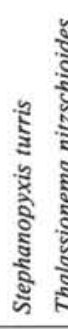 & 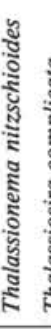 & 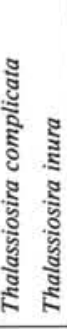 & 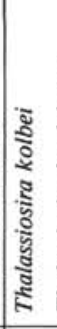 & 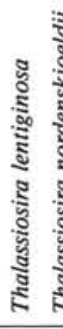 & 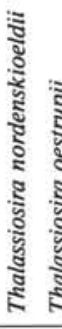 & 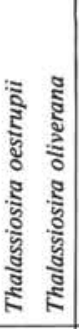 & 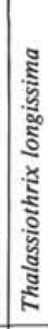 \\
\hline $\begin{array}{l}\text { T. lentiginosa- } \\
\text { T. kolbei }\end{array}$ & $\begin{array}{l}1 \mathrm{H}-1,20-21 \\
1 \mathrm{H}-1,55-56 \\
1 \mathrm{H}-2,30-31 \\
1 \mathrm{H}-3,30-31 \\
1 \mathrm{H}-4,30-31 \\
1 \mathrm{H}-4,100-101 \\
1 \mathrm{H}, \mathrm{CC} \\
\end{array}$ & $\begin{array}{l}\mathrm{R} \\
\mathrm{R} \\
\mathrm{R} \\
\mathrm{R} \\
\mathrm{R} \\
\mathrm{A} \\
\mathrm{A} \\
\end{array}$ & \begin{tabular}{l|}
$\mathrm{P}$ \\
$\mathrm{P}$ \\
$\mathrm{P}$ \\
$\mathrm{P}$ \\
$\mathrm{P}$ \\
$\mathrm{G}$ \\
$\mathrm{G}$ \\
\end{tabular} & $\begin{array}{lr}\mathrm{R} & \\
\mathrm{R} & \\
\mathrm{R} & \\
& \\
& \mathrm{R} \\
& \mathrm{F} \\
\end{array}$ & & & $\begin{array}{l}\mathrm{F} \\
\mathrm{F} \\
\mathrm{R} \\
\mathrm{F} \\
\mathrm{R} \\
\mathrm{F} \\
\end{array}$ & & & $\begin{array}{l}\mathrm{R} \\
\mathrm{F}\end{array}$ & & & & $\begin{array}{ll}F & \\
F & R \\
F & \end{array}$ & & $\begin{array}{l}\mathrm{R} \\
\mathrm{F} \\
\mathrm{F} \\
\end{array}$ & & & & & $\begin{array}{l}\mathrm{R} \\
\mathrm{R} \\
\mathrm{F} \\
\\
\mathrm{F}\end{array}$ & & & \\
\hline $\begin{array}{c}\text { Nitzschia } \\
\text { interfrigidaria/ } \\
\text { Cosmiodiscus } \\
\text { insignis }\end{array}$ & $\begin{array}{l}2 \mathrm{H}-6,70-71 \\
2 \mathrm{H}, \mathrm{CC} \\
3 \mathrm{H}-4,21-22 \\
3 \mathrm{H}-5,75-76 \\
3 \mathrm{H}, \mathrm{CC} \\
4 \mathrm{H}, \mathrm{CC} \\
5 \mathrm{H}, \mathrm{CC} \\
6 \mathrm{H}, \mathrm{CC}\end{array}$ & $\begin{array}{l}\mathrm{C} \\
\mathrm{C} \\
\mathrm{C} \\
\mathrm{F} \\
\mathrm{C} \\
\mathrm{A} \\
\mathrm{C} \\
\mathrm{A}\end{array}$ & \begin{tabular}{l|}
$\mathrm{M}$ \\
$\mathrm{M}$ \\
$\mathrm{M}$ \\
$\mathrm{M}$ \\
$\mathrm{M}$ \\
$\mathrm{G}$ \\
$\mathrm{M}$ \\
$\mathrm{G}$
\end{tabular} & $\begin{array}{ll}\mathrm{R} & \mathrm{R} \\
& \mathrm{R}\end{array}$ & $\begin{array}{l}\mathrm{F} \\
\mathrm{F}\end{array}$ & & $\begin{array}{l}\mathrm{F} \\
\mathrm{R} \\
\mathrm{R} \\
\mathrm{F} \\
\mathrm{F} \\
\mathrm{R}\end{array}$ & & $\begin{array}{ll}\mathrm{F} & \\
\mathrm{F} & \\
\mathrm{R} & \\
\mathrm{R} & \mathrm{R} \\
\mathrm{R} & \end{array}$ & $\begin{array}{l}\mathrm{R} \\
\mathrm{R} \\
\mathrm{R} \\
\mathrm{R} \\
\mathrm{R} \\
\mathrm{R}\end{array}$ & $\begin{array}{l}\mathrm{R} \\
\mathrm{R}\end{array}$ & R & $\begin{array}{l}\mathrm{R} \\
\mathrm{C} \\
\mathrm{C} \\
\mathrm{C} \\
\mathrm{F} \\
\mathrm{F} \\
\mathrm{F} \\
\mathrm{R}\end{array}$ & $\begin{array}{ll}R & \\
C & \\
C & \\
C & \\
F & \\
F & R \\
F & \\
R & \\
\end{array}$ & $\begin{array}{l}\mathrm{R} \\
\mathrm{R} \\
\mathrm{F} \\
\mathrm{R}\end{array}$ & F & $\begin{array}{l}\mathrm{F} \\
\mathrm{C} \\
\mathrm{F}\end{array}$ & & $\begin{array}{ll}R & \\
R & R \\
\end{array}$ & $\mathbf{R}$ & $\begin{array}{l}\mathrm{R} \\
\mathrm{F} \\
\mathrm{R}\end{array}$ & & $\begin{array}{l}\mathrm{R} \\
\mathrm{R}\end{array}$ & F \\
\hline $\begin{array}{l}\text { Nitzschia } \\
\text { barronii }\end{array}$ & $\begin{array}{l}7 \mathrm{H}, \mathrm{CC} \\
9 \mathrm{H}, \mathrm{CC} \\
10 \mathrm{H}, \mathrm{CC} \\
12 \mathrm{H}, \mathrm{CC} \\
13 \mathrm{H}, \mathrm{CC} \\
14 \mathrm{H}, \mathrm{CC} \\
15 \mathrm{H}, \mathrm{CC}\end{array}$ & $\begin{array}{l}\mathrm{F} \\
\mathrm{F} \\
\mathrm{C} \\
\mathrm{C} \\
\mathrm{C} \\
\mathrm{R} \\
\mathrm{C}\end{array}$ & \begin{tabular}{|l|l|}
$\mathrm{M}$ & \\
$\mathrm{M}$ & \\
$\mathrm{M}$ & \\
$\mathrm{M}$ & \\
$\mathrm{M}$ & \\
$\mathrm{P}$ & \\
$\mathrm{M}$ & \\
\end{tabular} & & & & $\begin{array}{l}\mathrm{R} \\
\mathrm{R} \\
\mathrm{R} \\
\mathrm{R} \\
\end{array}$ & & $\begin{array}{ll}\mathrm{R} & \\
\mathrm{R} & \\
\mathrm{R} & \mathrm{R} \\
\mathrm{R} & \\
\mathrm{R} & \\
\end{array}$ & & $\begin{array}{l}\mathrm{R} \\
\mathrm{R} \\
\mathrm{R} \\
\mathrm{F} \\
\mathrm{R} \\
\mathrm{R} \\
\mathrm{R}\end{array}$ & $\begin{array}{l}\mathbf{R} \\
\mathrm{R} \\
\mathrm{R}\end{array}$ & & $\begin{array}{l}\mathrm{R} \\
\mathrm{R}\end{array}$ & $\mathbf{R}$ & & $\begin{array}{ll}\mathrm{F} & \\
\mathrm{F} & \\
\mathrm{F} & \mathrm{F} \\
\mathrm{F} & \mathrm{F} \\
\mathrm{F} & \mathrm{F} \\
\mathrm{X} & \\
\mathrm{R} & \mathrm{F}\end{array}$ & $\begin{array}{lll} & \mathrm{F} \\
& \mathrm{F} \\
\mathrm{F} & \mathrm{F} \\
\mathrm{F} & \mathrm{F} \\
\mathrm{F} & \mathrm{F} \\
& \mathrm{X} \\
\mathrm{F} & \mathrm{F}\end{array}$ & $\begin{array}{ll}R & R \\
R & R \\
R & \\
R & R \\
R & R \\
X & \\
R & R\end{array}$ & & & & $\begin{array}{l}\mathrm{R} \\
\mathrm{R} \\
\mathrm{R} \\
\mathrm{R} \\
\mathrm{X} \\
\mathrm{R} \\
\mathrm{R}\end{array}$ & $\begin{array}{l}X \\
F\end{array}$ \\
\hline $\begin{array}{l}\text { Thalassiosira } \\
\text { inura }\end{array}$ & $\begin{array}{l}16 \mathrm{H}, \mathrm{CC} \\
18 \mathrm{X}, \mathrm{CC} \\
19 \mathrm{X}, \mathrm{CC} \\
20 \mathrm{X}, \mathrm{CC} \\
21 \mathrm{X}, \mathrm{CC} \\
22 \mathrm{X}, \mathrm{CC} \\
23 \mathrm{X}, \mathrm{CC}\end{array}$ & $\begin{array}{l}\text { C } \\
\text { C } \\
\text { C } \\
\text { A } \\
\text { C } \\
\text { C } \\
\text { A }\end{array}$ & \begin{tabular}{|l|}
$M$ \\
$M$ \\
$M$ \\
$M$ \\
$M$ \\
$M$ \\
$M$ \\
$G$
\end{tabular} & $R$ & & $\begin{array}{ll}R & \\
R & R\end{array}$ & $\begin{array}{l}\mathrm{R} \\
\mathrm{R} \\
\mathrm{R} \\
\mathrm{R} \\
\mathrm{F} \\
\mathrm{R}\end{array}$ & $\begin{array}{l}\mathrm{R} \\
\mathrm{R} \\
\mathrm{R} \\
\mathrm{F} \\
\\
\mathrm{R}\end{array}$ & $\begin{array}{l}\mathrm{R} \\
\mathrm{R}\end{array}$ & & $\begin{array}{l}R \\
F \\
F \\
R \\
R \\
R \\
F\end{array}$ & $\begin{array}{l}\mathrm{R} \\
\mathrm{R} \\
\mathrm{R} \\
\mathrm{R}\end{array}$ & $\mathbf{R}$ & $\begin{array}{l}\mathrm{R} \\
\mathrm{R} \\
\mathrm{R} \\
\mathrm{R}\end{array}$ & & $\begin{array}{ll}\mathrm{R} \\
\mathrm{F} \\
\mathrm{R}\end{array}$ & $\begin{array}{ll}R & R \\
R & \\
\text { F } & \\
& R \\
\text { R } & F\end{array}$ & $\begin{array}{lll}R & F \\
& F \\
& F \\
& F \\
& F \\
& F \\
F & F\end{array}$ & $\begin{array}{ll}R & R \\
R & R \\
R & \\
R & \\
R & R \\
R & \\
R & R\end{array}$ & & & $\begin{array}{ll}\mathrm{R} & \mathrm{R} \\
& \mathrm{R} \\
& \mathrm{R} \\
& \mathrm{R} \\
& \\
& \\
\mathrm{R} & \mathrm{R}\end{array}$ & $\begin{array}{l}\mathrm{R} \\
\mathrm{R} \\
\mathrm{R} \\
\mathrm{R} \\
\\
\mathrm{R}\end{array}$ & $\begin{array}{l}\text { R } \\
R \\
R \\
F \\
F \\
F \\
F\end{array}$ \\
\hline $\begin{array}{l}\text { Cosmiodiscus } \\
\text { intersectus }\end{array}$ & $\begin{array}{l}25 \mathrm{X}, \mathrm{CC} \\
26 \mathrm{X}, \mathrm{CC} \\
29 \mathrm{X}, \mathrm{CC} \\
35 \mathrm{X}, \mathrm{CC} \\
36 \mathrm{X}, \mathrm{CC} \\
37 \mathrm{X}, \mathrm{CC} \\
39 \mathrm{X}, \mathrm{CC} \\
40 \mathrm{X}, \mathrm{CC} \\
41 \mathrm{X}, \mathrm{CC}\end{array}$ & $\begin{array}{l}\mathrm{R} \\
\mathrm{C} \\
\mathrm{R} \\
\mathrm{F} \\
\mathrm{F} \\
\mathrm{R} \\
\mathrm{R} \\
\mathrm{R} \\
\mathrm{R}\end{array}$ & \begin{tabular}{|l|}
$\mathrm{P}$ \\
$\mathrm{M}$ \\
$\mathrm{P}$ \\
$\mathrm{M}$ \\
$\mathrm{M}$ \\
$\mathrm{P}$ \\
$\mathrm{P}$ \\
$\mathrm{P}$ \\
$\mathrm{P}$
\end{tabular} & $x$ & & 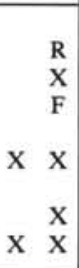 & $\begin{array}{l}\mathrm{R} \\
\mathrm{R}\end{array}$ & $\begin{array}{l}\mathrm{X} \\
\mathrm{F} \\
\mathrm{R}\end{array}$ & & & $\begin{array}{l}\mathrm{X} \\
\mathrm{F} \\
\mathrm{X}\end{array}$ & $\mathbf{R}$ & & & & $\begin{array}{l}\mathrm{R} \\
\mathrm{X} \\
\mathrm{X} \\
\mathrm{X} \\
\mathrm{X}\end{array}$ & & $\begin{array}{l}x \\
x\end{array}$ & & & & & & $\begin{array}{l}\mathrm{F} \\
\mathrm{F}\end{array}$ \\
\hline
\end{tabular}

Compared to other sites on Leg 113, the Quaternary and upper Pliocene sediment sequence at Site 697 is expanded. However, because of generally poor preservation, the range of the $T$. lentiginosa, $A$. ingens, and T. kolbei Zones is not well documented. The base of the $N$. interfrigidaria/C. insignis Zone is between Sections 113-697B-19X-CC and -18X-CC. The base of the $N$. barronii Zone is tentatively placed between Section 113697B-21X-CC and Sample 113-697B-21X-2, 15-16 cm, and the base of the underlying $T$. inura Zone is between Section 113697B-28X-CC and Sample 113-697B-28X-3, 114-115 cm.

\section{ACKNOWLEDGMENTS}

The authors are grateful to John A. Barron for fruitful discussions on Neogene diatom biostratigraphy, critical review of the manuscript, and for many useful suggestions. For the review of the manuscript we also thank George Andrews. We are very grateful to Andrea Abelmann, David Lazarus, and Volkhard Spieß for many discussions on the stratigraphy of Sites 689 and 690 , and for making available radiolarian biostratigraphic and magnetostratigraphic data which were important and helpful for the establishment of the Neogene Antarctic diatom biostra- tigraphy. Norman Hamilton and Paul O'Brien contributed paleomagnetic data of Holes 695A, 697A, and 697B. We thank Ruth Cordelair and Ute Bock for laboratory and technical assistance.

This work was supported by the Deutsche Forschungsgemeinschaft. This is Alfred Wegener Institute Contribution 216.

\section{TAXONOMIC NOTES AND FLORAL REFERENCES}

A taxonomic paper including the description of new Miocene taxa follows this paper (Gersonde, this volume). Descriptions of other new Pliocene species are in Gersonde (in press). The first citation in the following list is the original description of the species, the second is more recent. In most cases only the second citation is included in the reference list. In parenthesis is the reference to the figure included in this paper.

Actinocyclus ingens Rattray, 1890. Whiting and Schrader, 1985.

Actinocyclus ingens var. nodus Baldauf in Baldauf and Barron, 1980, p. 104 , pl. 1 , figs. 5-9.

Actinocyclus ingens var. ovalis Gersonde (this volume) (Pl. 5, Fig. 4).

Actinocyclus octonarius Ehrenberg 1845. Hustedt, 1930, p. 525, fig. 298 (as A. ehrenbergii Ralfs in Pritchard).

Actinoptychus senarius Ehrenberg, 1862. Hustedt, 1930, p. 475, fig. 264 (as A. undulatus (Bail.) Ralfs in Pritchard). 


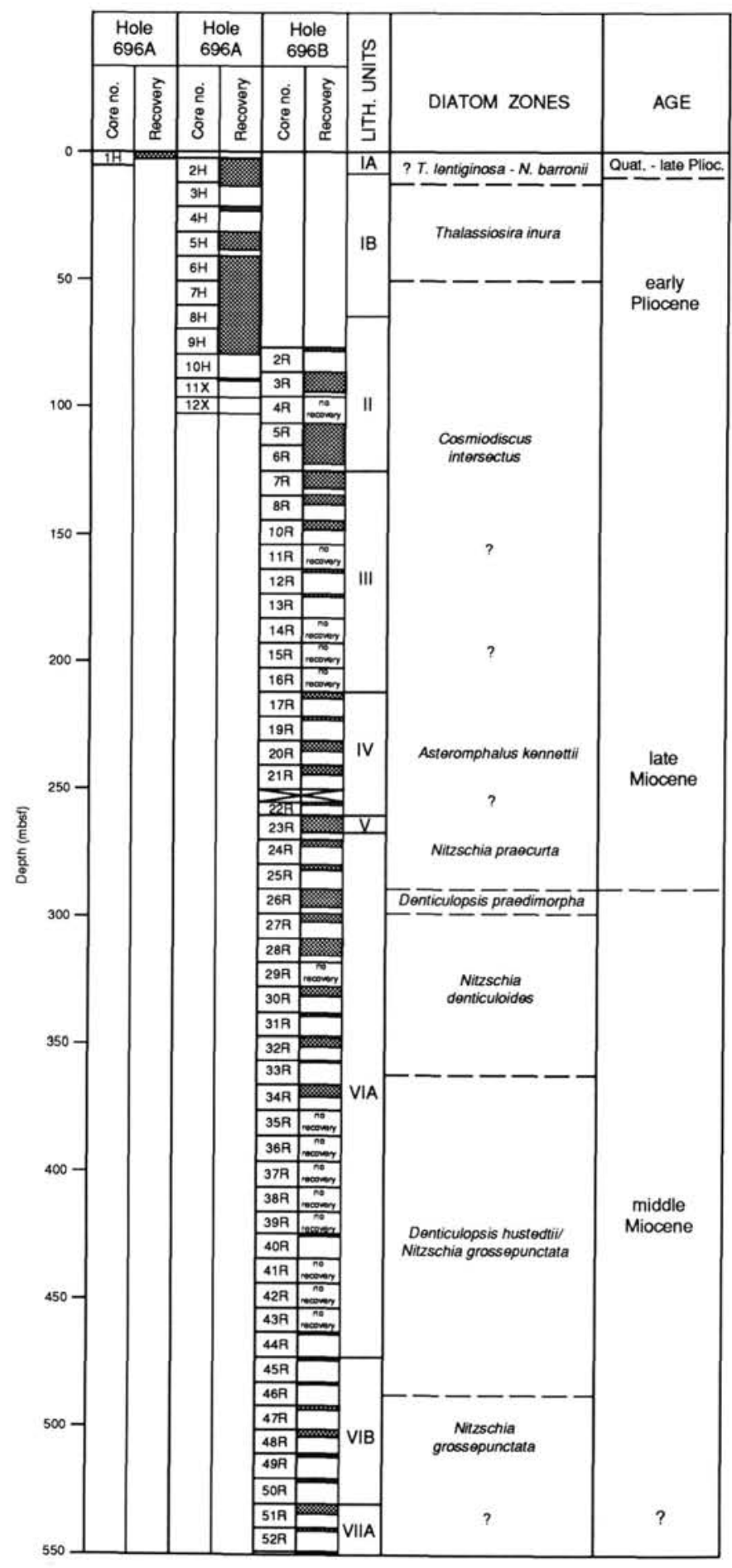

Figure 11. Diatom biostratigraphy of Holes 696A and 696B.

Asteromphalus hookeri Ehrenberg, 1844. Hustedt, 1958, p. 127, pl. 8, fig. 89. Asteromphalus inaequabilis Gersonde (this volume). Asteromphalus kennettii Gersonde (this volume) (Pl. 5, Fig. 6). Asteromphalus oligocenicus Schrader and Fenner, 1976, pl. 5, figs. 5-7. Azpeitia nodulifer (Schmidt) Fryxell and Sims in Fryxell et al., 1986, p. 19 , figs. $17,18-1,-2,-3,-5,30-3,-4$.

Azpeitia tabularis-group. Includes the following species: $A$. tabularis Fryxell and Sims, $A$. elegantula (Greville) Sims, and $A$. endoi (Kanaya) Sims and Fryxell. All species are described and figured in Fryxell et al. (1986).
Coscinodiscus elliptopora Donahue, 1970. Gombos, 1977, p. 592, pl. 3 , figs. $1-3,6$; pl. 9 , fig. 3 .

Coscinodiscus lewisianus Greville, 1866. Schrader, 1973, pl. 8, figs. 1-6, $10,15$.

Coscinodiscus marginatus Ehrenberg, 1841. Hustedt, 1930, p. 416, fig. 223.

Coscinodiscus rhombicus Castracane, 1886. Schrader and Fenner, 1976, pl. 21, figs. 1-3, 5 .

Coscinodiscus vulnificus Gombos, 1977, p. 593, pl. 4, figs. 1-3; pl. 42, figs. 1-2.

Cosmiodiscus insignis Jousé, 1961. McCollum, 1975, pl. 8, fig. 5.

Cosmiodiscus intersectus (Brun) Jousé, 1961, p. 68, pl. 2, figs. 9, 10 (Pl. 4, Fig. 13).

Crucidenticula kanayae Akiba and Yanagisawa, 1985, p. 486, pl. 1, figs. 3-8; pl. 3, figs. 1-6, 9-10 (Pl. 3, Figs. 11-12).

Crucidenticula nicobarica (Grunow) Akiba and Yanagisawa, 1985, p. 486, pl. 1, fig. 9; pl. 2, figs. 1-7; pl. 5, figs. 1-9 (Pl. 3, Figs. 18-19).

Crucidenticula punctata (Schrader) Akiba and Yanagisawa, 1985, p. 487, pl. 1, figs. 10-12; pl. 4, figs. 1-9 (Pl. 4, Fig. 9).

Denticulopsis dimorpha (Schrader) Simonsen, 1979. Akiba and Yanagisawa, 1985, p. 488, pl. 15, figs. 1-25; pl. 16, figs. 1-11 (PI. 4, Figs. 10-12).

Denticulopsis hustedtii (Simonsen and Kanaya) Simonsen, 1979. Akiba and Yanagisawa, 1985, p. 488, pl. 17, figs. 4-5, 7-23; pl. 18, figs. 110; pl. 19, figs. 1-5 (PI. 5, Figs. 10-13).

Denticulopsis lauta (Bailey) Simonsen, 1979. Akiba and Yanagisawa, 1985 , p. 489 , pl. 7 , figs. $16-29$; pl. 9 , figs. 1-9.

Denticulopsis maccollumii Simonsen, 1976. Schrader, 1976, p. 631, pl. 4, figs. 3, 22, 23, 25 (as Denticula antarctica McCollum) (Pl. 5, Figs. 7-9).

Denticulopsis praedimorpha Barron ex Akiba, 1982. Akiba and Yanagisawa, 1985 , p. 489 , pl. 13 , figs. 1-28; pl. 14, figs. 1-12.

Ethmodiscus rex (Rattray) Wiseman and Hendey, 1953. Round, 1980.

Eucampia balaustium Castracane, 1886. Syvertsen and Hasle, 1983, p. 181 , figs. 4, 84-129. Synonym is E. antarctica (Castr.) Mangin, 1914.

Hemidiscus cuneiformis Wallich. Hustedt, 1930, p. 904, fig. 542.

Katathiraia aspera Komura, 1976, p. 385, fig. 5 (Pl. 4, Fig. 8).

Lisitzina ornata Jousé, 1978. Gombos and Ciesielski, 1983, p. 603, pl. 18 , figs. 1-4.

Mediaria splendida Sheshukova-Poretzkaya, 1962. Schrader, 1973, p. 706, pl. 3, figs. 14-15 (Pl. 4, Fig. 14).

Neobrunia mirabilis (Brun in Brun and Tempere) Kuntze, 1898. Hendey, 1981, p. 86.

Nitzschia angulata (O'Meara) Hasle, 1972. Fenner et al., 1976, p. 775, pl. 1 , figs. 17-39.

Nitzschia arcula Gersonde, in press (Pl. 1, Figs. 25-26).

Nitzschia aurica Gersonde, in press (PI. 2, Figs. 10-12).

Nitzschia barronii Gersonde, in press (Pl. 1, Figs. 11-13).

Nitzschia claviceps Schrader, 1976, p. 633, pl. 2, figs. 2, 4 (Pl. 2, Figs. 20-21).

Nitzschia clementia Gombos, 1977, p. 595, pl. 8, figs. 18, 19 (Pl. 2, Figs. 22-23).

Nitzschia curta (V. Heurck) Hasle, 1972. Fenner et al., 1976, p. 775, pl. 4 , figs. 5-9.

Nitzschia cylindrica Burckle, 1972, p. 239, pl. 2, figs. 1-6 (Pl. 1, Fig. 27).

Nitzschia denticuloides Schrader, 1976, p. 633, pl. 3, figs. 7, 8, 10, 12, 18-24 (Pl. 2, Figs. 7-8).

Nitzschia donahuensis Schrader, 1976, p. 633, pl. 2, fig. 30 (Pl. 1, Figs. 16-18).

Nitzschia efferans Schrader, 1976, p. 633, pl. 2, figs. 1, 3, 5-7 (Pl. 2, Fig. 9).

Nitzschia fossilis (Frenguelli) Kanaya in Kanaya and Koizumi, 1970. Schrader, 1973, p. 707, pl. 4, figs 9-11, 24, 25 (Pl. 1, Figs. 19-20).

Nitzschia grossepunctata Schrader, 1976, p. 633, pl. 3, figs. 1-4 (Pl. 2, Figs. 3-6).

Nitzschia interfrigidaria McCollum, 1975, p. 535, pl. 9, figs. 7-9 (Pl. 1, Figs. 1-3).

Nitzschia januaria Schrader, 1976, p. 634, pl. 2, figs. 25-29.

Nitzschia kerguelensis (O'Meara) Hasle, 1972. Fenner et al., 1976, p. 776 , pl. 2, figs. 19-30.

Nitzschia lacrima Gersonde, in press (Pl. 1, Figs. 14-15).

Nitzschia maleinterpretaria Schrader, 1976, p. 634, pl. 2, figs. 9, 11-19. 
Table 9. Stratigraphic occurrences of selected diatom species from the Neogene of Holes 696A and 696B. Abbreviations are explained in Table 3.

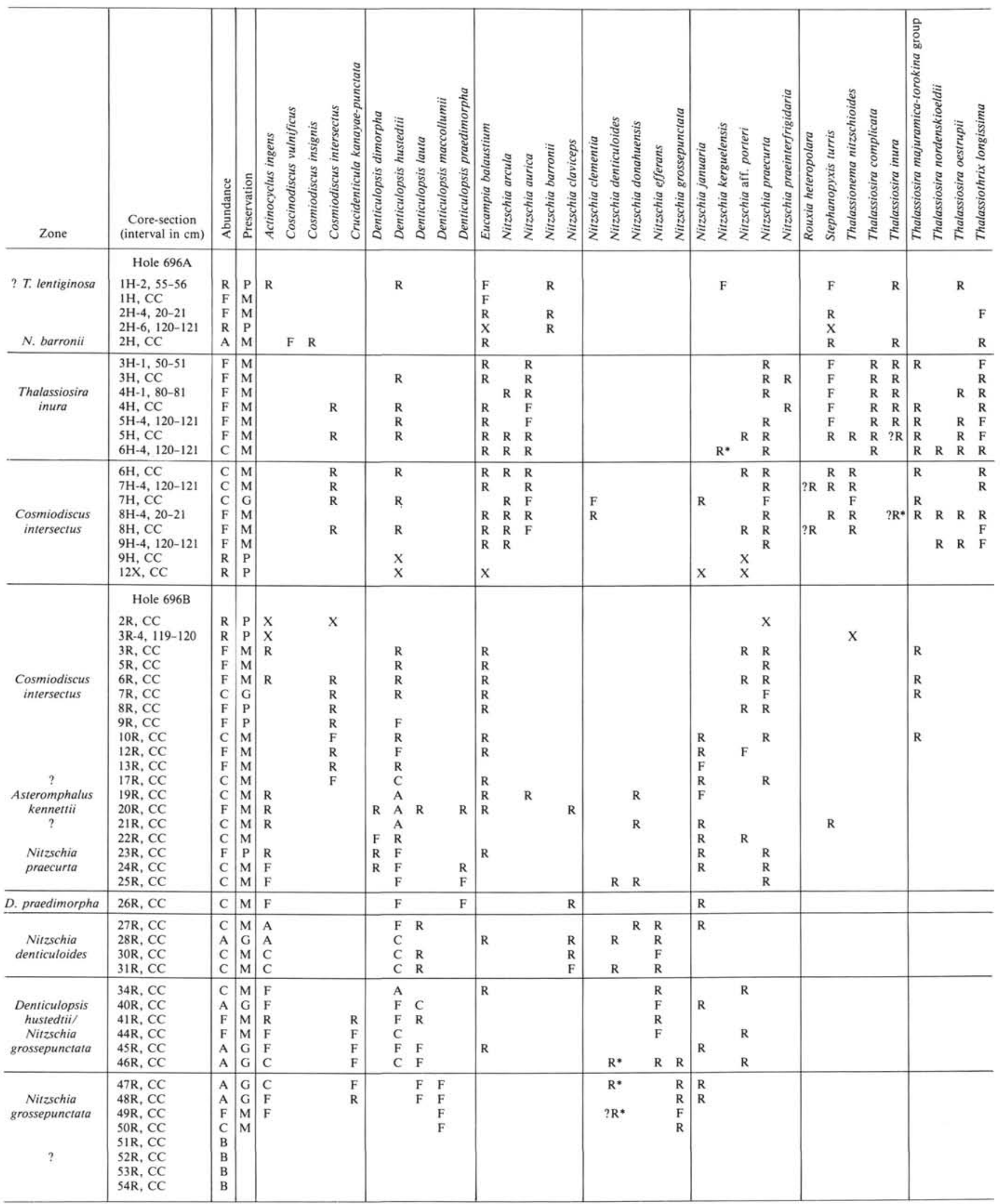




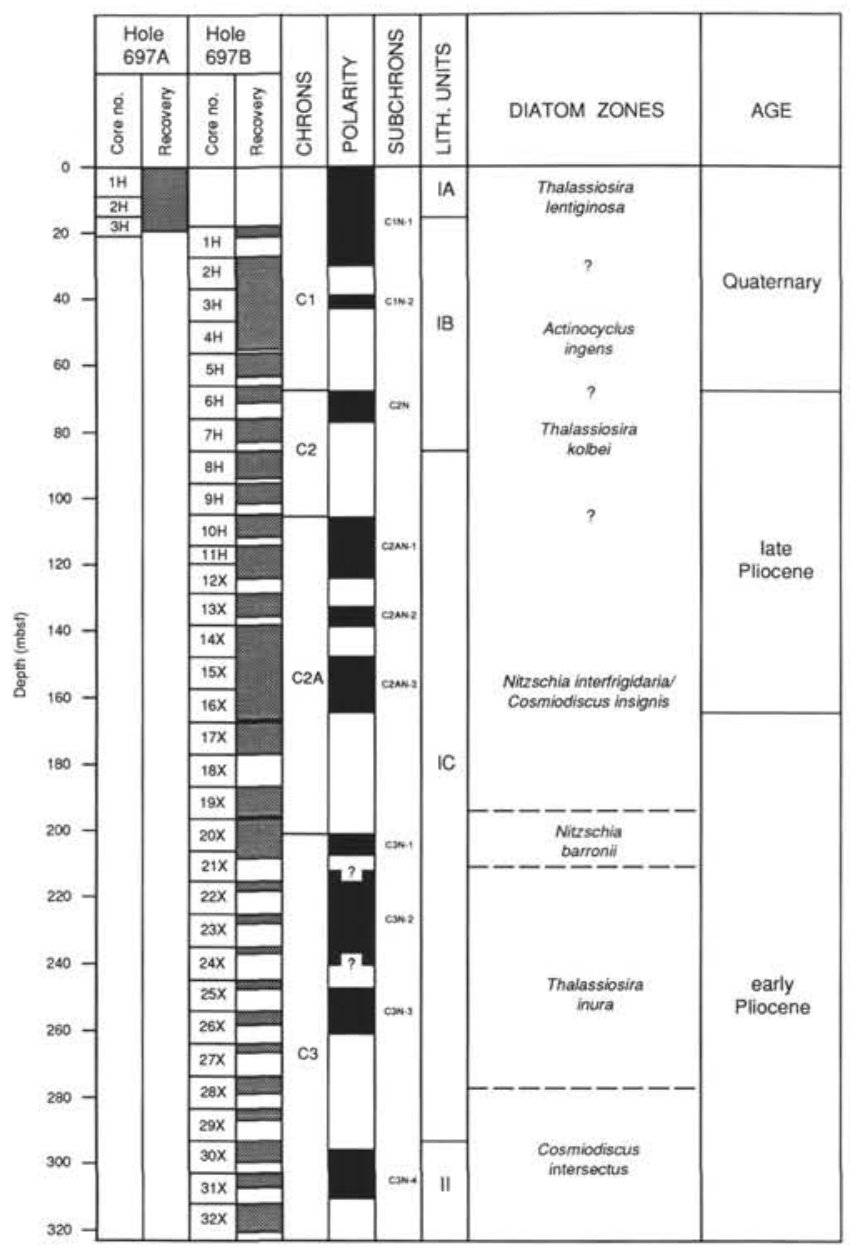

Figure 12. Diatom biostratigraphy of Holes 697A and 697B. Paleomagnetic data according to Hamilton and O'Brien (unpubl. data, also compare Gersonde et al., this volume).

Remark. The species Nitzschia evenescens Schrader, 1976, p. 633, pl. 2, figs. 22,23 , which differs only by its slightly finer structure from $N$. maleinterpretaria, was included in $N$. maleinterpretaria ( $\mathrm{Pl}$. 2, Figs. 13-16).

Nitzschia praecurta Gersonde, in press (PI. 1, Figs. 21-24).

Nitzschia praeinterfrigidaria McCollum, 1975, p. 535, pl. 10, fig. 1 (Pl. 1, Figs. 4-10)

Nitzschia pseudokerguelensis Schrader, 1976, p. 634, pl. 15, figs. 13-15 (Pl. 2, Fig. 2).

Nitzschia pusilla Schrader, 1976, p. 634, pl. 2, fig. 20 (Pl. 2, Figs. 1719).

Nitzschia reinholdii Kanaya ex Schrader, 1973. Akiba and Yanagisawa, 1985, p. 496, pl. 40, figs. 8-9; pl. 41, figs. 3-4 (Pl. 2, Fig. 1).

Raphidodiscus marylandicus Christian, 1887. Andrews, 1973, p. 233, pls. 1-5 (Pl. 5, Fig. 5).

Rhizosolenia alata Brightwell, 1858. Hustedt, 1930, p. 600, figs. $345-$ 348.

Rhizosolenia barboi (Brun) Tempere and Peragallo. Akiba and Yanagisawa, 1985, p. 495, pl. 42, figs. 3-5, 7, 10-11; pl. 44, figs. 1-8.

Rhizosolenia costata Gersonde, in press (PI. 3, Fig. 6).

Rhizosolenia hebetata Gran, 1904. Hustedt, 1930, p. 590.

Rhizosolenia styliformis Brightwell, 1858 . Hustedt, 1930, p. 584, figs. 333-335.

Rocella gelida (Mann) Bukry, 1978, pl. 5, figs. 1-13.

Remark. $R$. gelida var. schraderi (Bukry) Barron, 1983, pl. 4, fig. 10, was included in $R$. gelida.

Rocella vigilans Fenner, 1984, pl. 1, fig. 11.

Rouxia antarctica Heiden and Kolbe, 1928, p. 632, pl. 4, fig. 90. Schrader 1976, pl. 5, figs. 1-8.
Rouxia heteropolara Gombos, 1974, p. 275 (Pl. 5, Fig. 2).

Rouxia isopolica Schrader, 1976, p. 635, pl. 5, figs. 9, 14, 15, 20.

Rouxia naviculoides Schrader, 1973, p. 710, pl. 3, figs. 27-32 (Pl. 4, Fig. 16).

Rouxia oligocaenica Schrader, 1976, p. 636.

Stellarima microtrias (Ehrenberg) Hasle and Sims, 1986, p. 111, figs. 18-27.

Stephanopyxis turris (Grev. and Arn.) Ralfs in Pritchard. Hustedt, 1930, p. 304 , fig. 140

Synedra jouseana Sheshukova-Poretzkaya, 1962. Schrader, 1973, p. 710, pl. 23, figs. 21-23, 25, 38 .

Synedra miocenica Schrader, 1976, p. 636, pl. 1, fig. 1.

Thalassionema nitzschioides Hustedt, 1930, p. 244, fig. 725.

Thalassiosira complicata Gersonde, in press (Pl. 4, Figs. 1-2).

Thalassiosira convexa var. aspinosa Schrader, 1974, p. 916, pl. 2, figs. 8-9, 13-21 (Pl. 3, Figs. 2-3).

Thalassiosira fraga Schrader in Schrader and Fenner, 1976. Akiba and Yanagisawa, 1985, p. 498, pl. 51, figs. 5-10; pl. 53, figs. 1-8 (Pl. 3, Figs. 9-10).

Thalassiosira gracilis (Karsten) Hustedt, 1958. Johansen and Fryxell, 1985 , p. 168 , figs. $8,58,59$.

Thalassiosira inura Gersonde, in press (PI. 3, Figs. 15-17; Pl. 5, Fig. 14).

Thalassiosira kolbei (Jousé) Gersonde (this volume) (Pl. 3, Fig. 1).

Thalassiosira lentiginosa (Janisch) Fryxell, 1977, p. 100, figs. 13, 14.

Thalassiosira majuramica-torokina group. Includes forms with affinities to T. majuramica Sheshukova-Poretzkaya, 1959, and T. torokina Brady, 1977, p. 122-123, figs. 1-5 (Pl. 3, Fig. 8).

Thalassiosira miocenica Schrader, 1974, p. 916, pl. 22, figs. 1-5, 11-13 (PI. 3, Figs. 4-5).

Thalassiosira nordenskioeldi Cleve. Hustedt, 1930, p. 321, fig. 157.

Thalassiosira oestrupii (Ostenfeld) Proshkina-Lavrenko, 1956. Schrader, 1973, p. 712, pl. 11, figs. 16-22, 26-33, 36, 39-45 (Pl. 3, Figs. 13-14).

Thalassiosira oliverana (O'Meara) Makarova and Nikolaev, 1984, pl. 1, figs $1-11$; pl. 2, figs. 1-11.

Remark. Makarova and Nikolaev (1984) transfer this taxon from Schimperiella, but spell the basionym Actinocyclus oliveranus O'Meara (1877) incorrectly as $A$. oliverianus and thus name the new combination incorrectly as $T$, oliveriana.

Thalassiosira praeconvexa Burckle, 1972, p. 241, pl. 2, figs. 7-9.

Thalassiosira spinosa Schrader, 1976, p. 636, pl. 6, figs. 5-7 (Pl. 4, Figs. 3-4).

Thalassiosira spumellaroides Schrader, 1976, p. 636, pl. 6, figs. 1-2 (P1. 3, Fig. 7).

Thalassiosira yabei (Kanaya) Akiba and Yanagisawa, 1985, p. 493, pl, 27 , figs. $1-2$; pl. 28 , figs. $1-9$.

Thalassiothrix longissima Cleve and Grunow, 1880. Hustedt, 1959, p. 247, fig. 726.

\section{REFERENCES}

Akiba, F., 1985. Middle Miocene to Quaternary diatom biostratigraphy in the Nankai Trough and Japan Trench, and modified lower Miocene through Quaternary diatom zones for middle-to-high latitudes of the North Pacific. In Kamagi, H., Karig, D. E., Coulbourn, W. C., et al., Init. Repts. DSDP, 87: Washington (U.S. Govt. Printing Office), 393-481.

Akiba, F., and Yanagisawa, Y., 1985. Taxonomy, morphostructure and phylogeny of the Neogene diatom zonal marker species in the middle-to-high latitudes of the North Pacific. In Kamagi, H., Karig, D. E., Coulbourn, W. C., et al., Init. Repts. DSDP, 87: Washington (U.S. Govt. Printing Office), 483-554.

Andrews, G., 1973. Systematic position and stratigraphic significance of the marine diatom Raphidodiscus marylandicus Christian. Beih., Nova Hedwigia, 45:231-250.

Baldauf, J. G., and Barron, J. A., 1980. Actinocyclus ingens var. nodus: a new, stratigraphically useful diatom of the circum-North Pacific. Micropaleontology, 26:103-110.

Barker, P. F., Kennett, J. P., et al., 1988. Proc. ODP, Init. Repts., 113: College Station, TX (Ocean Drilling Program).

Barron, J. A., 1983. Latest Oligocene through early middle Miocene diatom biostratigraphy of the eastern tropical Pacific. Mar. Micropaleontol., 7:487-515. 
1985. Miocene to Holocene planktic diatoms. In Bolli, H. M., Saunders, J. B., and Perch-Nielsen, K. (Eds.), Plankton Stratigraphy: Cambridge (Cambridge Univ. Press), 763-809.

Berggren, W. A., Kent, D. V., and Van Couvering, J. A., 1985. The Neogene: Part 2, Neogene geochronology and chronostratigraphy. In Snelling, N. J. (Ed.), Geochronology of the geological record. Geol. Soc. Am. Mem., 10:211-260.

Brady, H. T., 1977. Thalassiosira torokina n. sp. (diatom) and its significance in late Cenozoic biostratigraphy. U.S. Antarct. J., 12:122123.

Bukry, D., 1978. Cenozoic silicoflagellate and coccolith stratigraphy, northwestern Atlantic Ocean Deep Sea Drilling Project Leg 43. In Benson, W. E., Sheridan, R. E., et al., Init. Repts. DSDP, 44: Washington (U.S. Govt. Printing Office), 775-805.

Burckle, L. H., 1972. Late Cenozoic planktonic diatom datum levels from the equatorial Pacific. Nova Hedwigia, 39:217-246.

Ciesielski, P. F., 1983. The Neogene and Quaternary diatom biostratigraphy of Subantarctic sediments, Deep Sea Drilling Project Leg 71. In Ludwig, W. J., Krasheninnikov, V. A., et al., Init. Repts. DSDP, 71: Washington (U.S. Govt. Printing Office), 635-665.

Fenner, J., 1984. Eocene-Oligocene planktic diatom stratigraphy in high and low latitudes. Micropaleontology, 30:319-342.

Fenner, J., Schrader, H. J., and Wienigk, H., 1976. Diatom phytoplankton studies in the Southern Pacific Ocean, composition and correlation to the Antarctic convergence and its paleoecological significance. In Hollister, C. D., Craddock, C., et al., Init. Repts. DSDP, 35: Washington (U.S. Govt. Printing Office), 757-813.

Fryxell, G. A., 1977. Thalassiosira australis PERAGALLO and T. lentiginosa (JANISCH) G. FRYXELL, comb. nov.: two Antarctic diatoms (Bacillariophyceae). Phycologia, 16:95-104.

Fryxell, G. A., Sims, P. A., and Watkins, T. P., 1986. Azpeitia (Bacillariophyceae): Related genera and promorphology. Syst. Bot. Monogr., 13:1-74.

Gersonde, R., in press. Taxonomy and morphostructure of Pliocene diatoms from the Maud Rise (Antarctic Ocean). Polarforschung.

Gersonde, R., and Cordes, D., in press. The sediments of Maud Rise (Atlantic Sector of Antarctic Ocean). Polarforschung.

Gombos, A. M., 1974. New species of fossil diatom from the Antarctic. U.S. Antarct. J., 9:275.

1977. Paleogene and Neogene diatoms from the Falkland Plateau and Malvinas Outer Basin: Leg 36, Deep Sea Drilling Project. In Barker, P. F., Dalziel, I.W.D., et al., Init. Repts. DSDP, 36: Washington (U.S. Govt. Printing Office), 575-687.

Gombos, A. M., and Ciesielski, P. F., 1983. Late Eocene to early Miocene diatoms from the Southwest Atlantic. In Ludwig, W. J., Krasheninnikov, V. A., et al., Init. Repts. DSDP, 71: Washington (U.S. Govt. Printing Office), 583-634.

Hasle, G. R., and Sims, P. A., 1896. The diatom genera Stellarima and Symbolophora with comments on the genus Actinoptychus. Br. Phycol. J., 21:97-114.

Heiden, H., and Kolbe, R. W., 1928. Die marinen Diatomeen der Deutschen Südpolar-Expedition 1901-1903. In Drygalski, E. von (Ed.), Deutsche Südpolar-Expedition 1901-1903, Bd. 8, Botanik, 450-714.

Hendey, N. I., 1981. Miocene diatoms from the Subantarctic southwest Pacific, DSDP Leg 29, Site 278, Core 10. Bacillaria, 4:65-124.

Hustedt, F., 1930. Die Kieselalgen Deutschlands, Österreichs und der Schweiz unter Berücksichtigung der übrigen Länder Europas sowie angrenzender Meeresgebiete, Teil 2. Rabenhorst, R. L. (Ed.), Kryptogamen-Flora, 7: Leipzig (Akad. Verlag.).

1958. Diatomeen aus der Antarktis und dem Südatlantik. Deutsche Antarktis Expedition 1938/1939, 2:103-191.

1959. Die Kieselalgen Deutschlands, Osterreichs und der Schweiz unter Berücksichtigung der übrigen Länder Europas sowie angrenzender Meeresgebiete, Teil 1. Rabenhorst, R. L. (Ed.), Kryptogamen-Flora 7: Leipzig (Akad. Verlag.).
Johansen, J. R., and Fryxell, G. A., 1985. The genus Thalassiosira (Bacillariophyceae): studies on species occurring south of the Antarctic Convergence Zone. Phycologia, 24:155-179.

Koizumi, I., 1980. Neogene diatoms from the Emperor Seamount Chain, Leg 55, Deep Sea Drilling Project. In Jackson, E. D., Koizumi, I., et al., Init. Repts. DSDP, 55: Washington (U.S. Govt. Printing Office), 387-407.

Komura, S., 1976. Sawamuraia, Katathiraia, und Yoshidaia, drei neue Diatomeengattungen aus dem Neogen Japans. Trans. Proc. Paleontontol. Soc. Japan, N.S., 103:379-397.

Ledbetter, M. T., 1983. Magnetostratigraphy of middle-upper Miocene and upper middle Eocene sections in Hole 512. In Ludwig, W. J., Krasheninnikov, V. A., et al., Init. Repts. DSDP, 71: Washington (U.S. Govt. Printing Office), 1093-1096.

McCollum, D. W., 1975. Diatom stratigraphy of the Southern Ocean. In Hayes, D. E., Frakes, L. A., et al., Init. Repts. DSDP, 28: Washington (U.S. Govt. Printing Office), 515-571.

Makarova, I. V., and Nikolajev, V. A., 1984. Notes on the Genus Schimperiella (Bacillariophyta). Bot. Zhurnal SSSR, 69:87-90 (in Russian).

Round, F. E., 1980. Forms of the giant diatom Ethmodiscus from the Pacific and Indian Ocean. Phycologia, 19:307-316.

Salloway, J. C., 1983. Paleomagnetism of sediments from Deep Sea Drilling Project Leg 71. In Ludwig, W. J., Krasheninnikov, V. A., et al., Init. Repts. DSDP, 71: Washington (U.S. Govt. Printing Office), 1073-1092.

Schrader, H. J., 1973. Cenozoic diatoms from the northeastern Pacific, Leg 18. In Kulm, L. D., von Huene, R., et al., Init. Repts. DSDP, 18: Washington (U.S. Govt. Printing Office), 673-797.

1974. Cenozoic marine planktonic diatom stratigraphy of the tropical Indian Ocean. In Fisher, R. L., Bunce, E. T., et al., Init. Repts. DSDP, 24: Washington (U.S. Govt. Printing Office), 887967.

1976. Cenozoic planktonic diatom biostratigraphy of the Southern Pacific Ocean. In Hollister, C. D., Craddock, C., et al., Init. Repts. DSDP, 35: Washington (U.S. Govt. Printing Office), 605671.

Schrader, H. J., and Fenner, J., 1976. Norwegian Sea Cenozoic diatom biostratigraphy and taxonomy. In Talwani, M., Udintsev, G., et al., Init. Repts. DSDP, 38: Washington (U.S. Govt. Printing Office), 921-1099.

Schrader, H. J., and Gersonde, R., 1978. Diatoms and silicoflagellates. In Zachariasse et al., Micropaleontological counting methods and techniques-an exercise on an eight meters section of the Lower Pliocene of Capo Rossello, Sicily. Utrecht Micropalentol. Bull., 17: 129-176.

Syvertsen, E. E., and Hasle, G. R., 1983. The diatom genus Eucampia: morphology and taxonomy. Bacillaria, 6:169-210.

Tauxe, L., Tucker, P., Petersen, N. P., and LaBreque, J. L., 1984. Magnetostratigraphy of Leg 73 sediments. In Hsü, K. J., LaBreque, J. L., et al., Init. Repts. DSDP, 73: Washington (U.S. Govt. Printing Office), 609-621.

Weaver, F. M., and Gombos, A. M., 1981. Southern high-latitude diatom biostratigraphy. Soc. Econ. Paleontol. Mineral. Spec. Publ., $32: 445-470$

Whiting, M. C., and Schrader, H., 1985. Actinocyclus ingens Rattray: Reinvestigation of a polymorphic species. Micropaleontology, 31: 68-75.

Date of initial receipt: 20 March 1989

Date of acceptance: 6 October 1989

Ms 113B-126 
Table 10. Stratigraphic occurrences of selected diatom species from Holes 697A and 697B. Abbreviations are explained in Table 3.

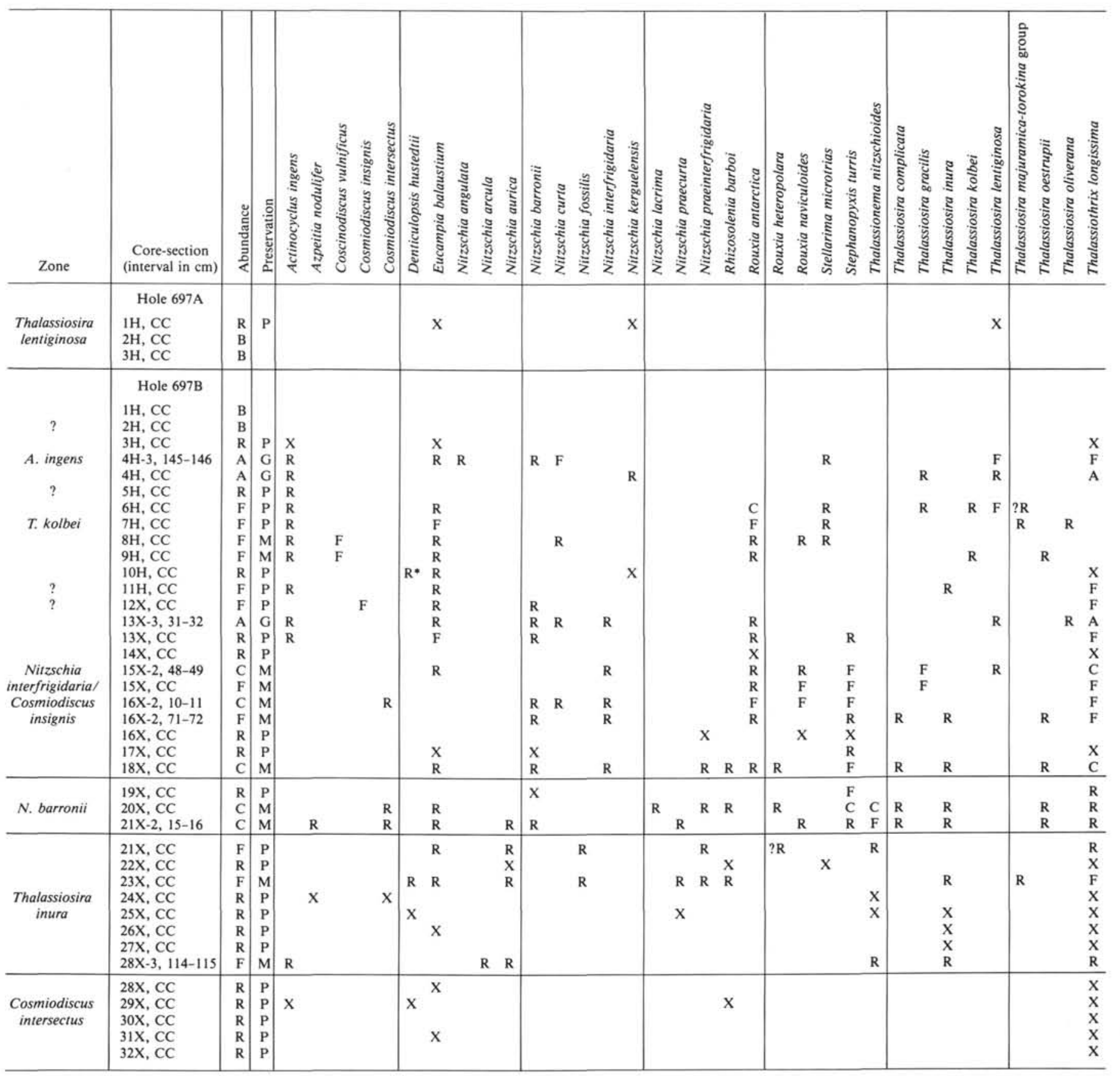


For the plates: All LM figures $\times 1500$ unless otherwise stated.
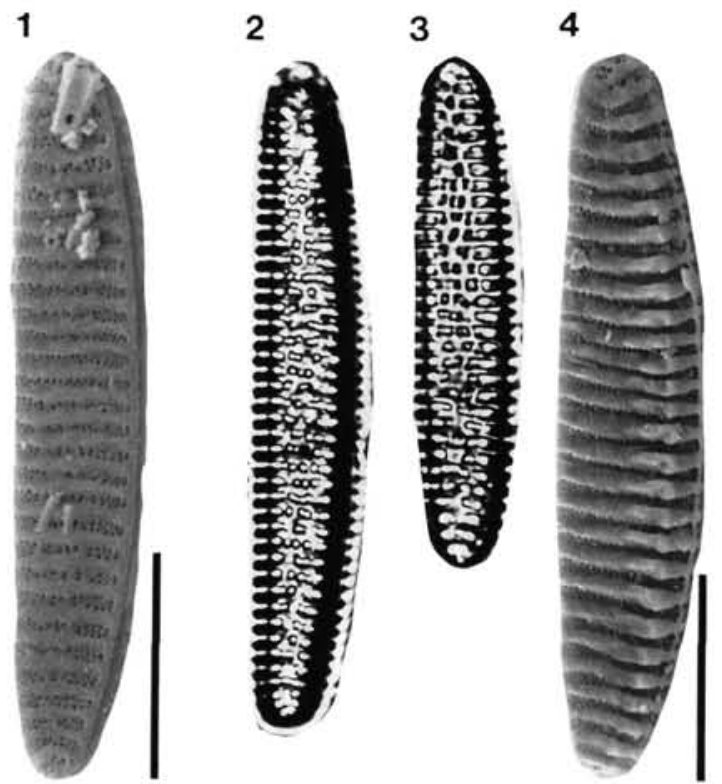

15
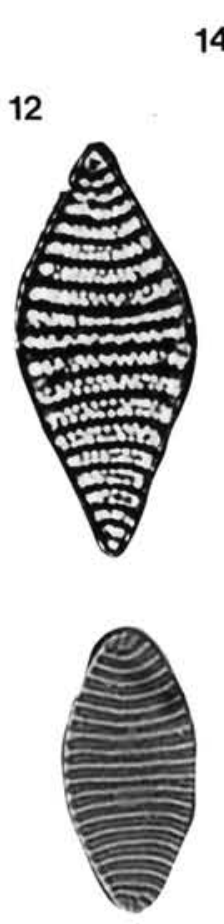

13
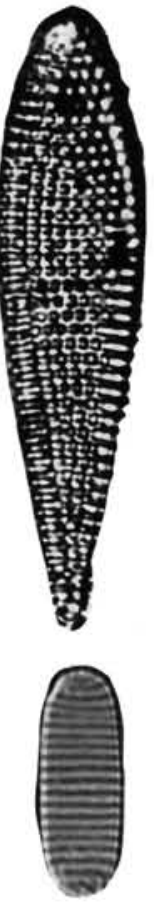

21

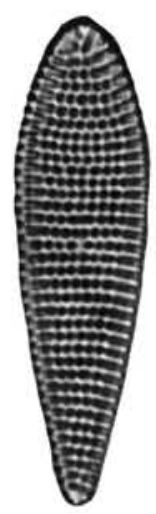

16
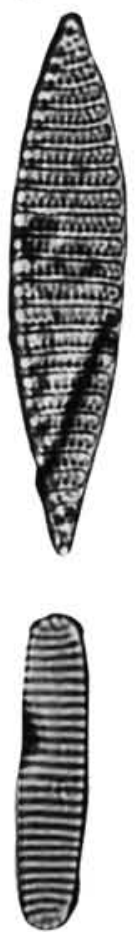

22

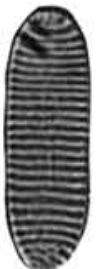

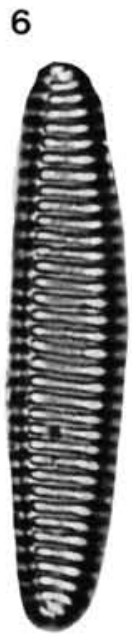

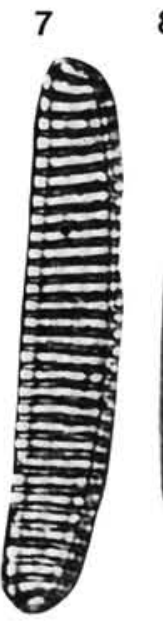

17

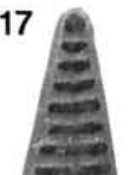

18
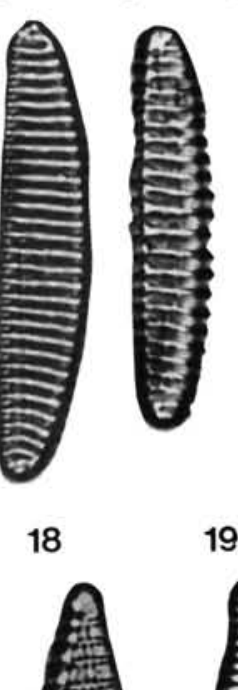

19

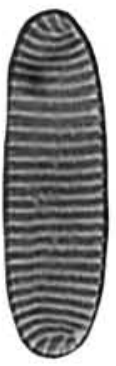

24
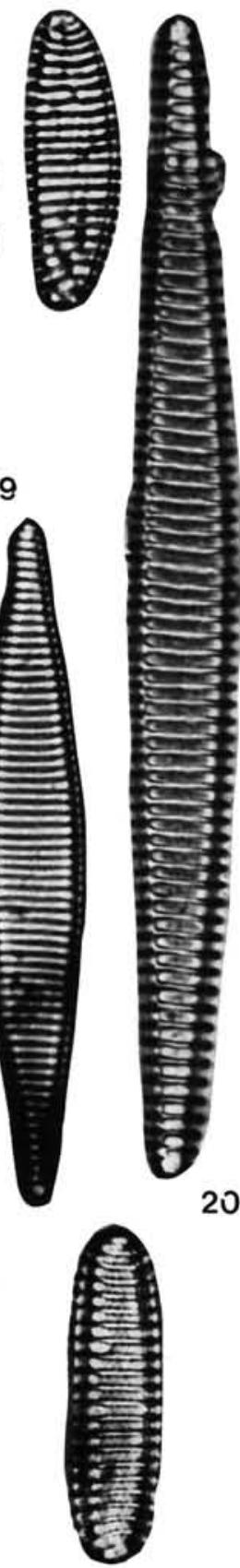

27

Plate 1. 1-3. Nitzschia interfrigidaria, Sample 113-689B-1H-1, 28-29 cm; (1) SEM external view of valve face, bar $=10 \mu \mathrm{m} .4-10$. Nitzschia praeinterfrigidaria; (4-7) Sample 113-689B-1H-4, 28-29 cm; (8-10) Sample 113-689B-1H-3, 114-115 cm; (4) SEM external view of valve face, bar = $10 \mu \mathrm{m}$. 11-13. Nitzschia barronii, Sample 113-689B-1H-3, 114-115 cm; (11) SEM external view of valve face, bar $=10 \mu \mathrm{m}$. 14-15. Nitzschia lacrima, Sample 113-689B-2H-2, 31-32 cm. 16-18. Nitzschia donahuensis; (16) Sample 113-689B-3H-2, 148-150 cm; (17) Sample 113-689B-4H-3, 114-115 cm, SEM external view of valve face, bar $=10 \mu \mathrm{m}$; (18) Sample 113-689B-4H-1, 112-113 cm. 19-20. Nitzschia fossilis, Sample 113-689B2H-6, 29-30 cm. 21-24. Nitzschia praecurta; (21) Sample 113-689B-5H-2, 86-88 cm; $(22,24)$ Sample 113-689B-3H-2, 148-150 cm; $(23)$ Sample $113-$ 689B-4H-1, 112-113 cm. 25-26. Nitzschia arcula; (25) Sample 113-689B-4H-1, 112-113 cm; (26) Sample 113-690B-3H-4, 27-28 cm. 27. Nitzschia cylindrica, Sample 113-689B-3H-5, 28-29 cm. 

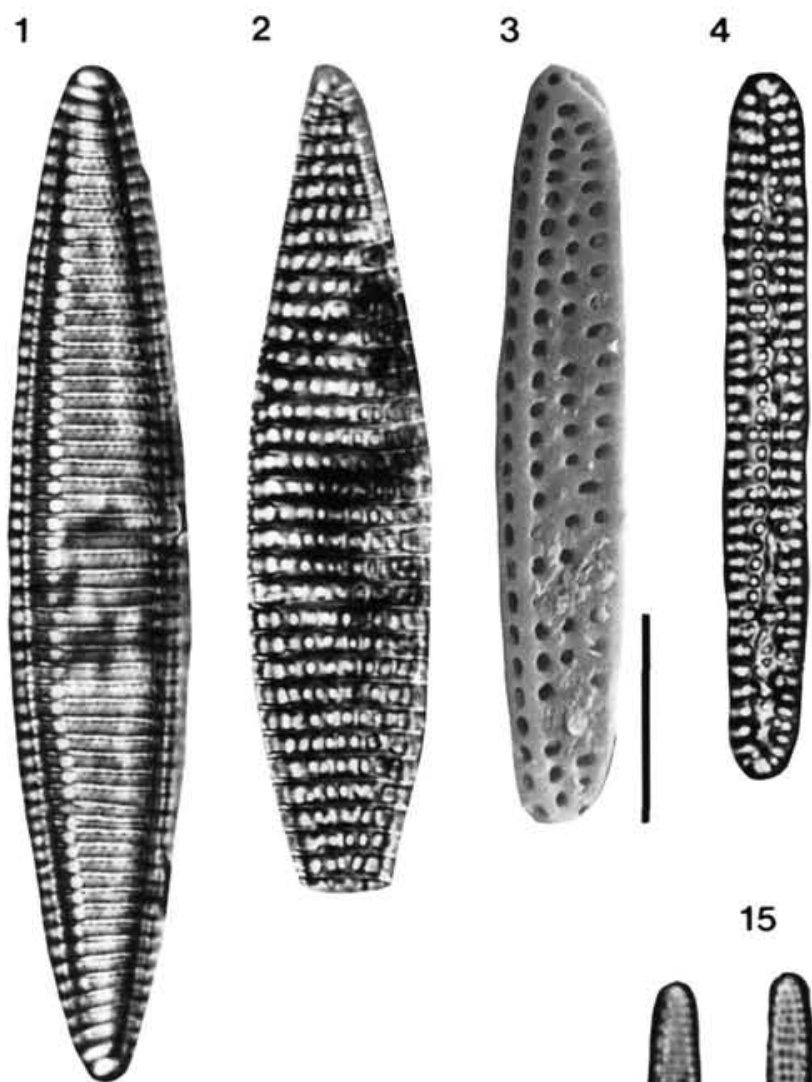

5

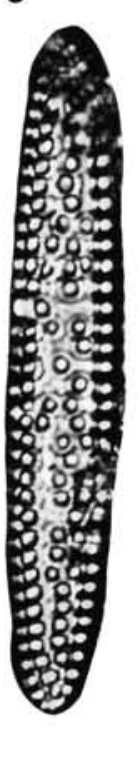

15

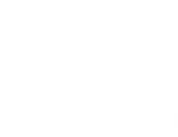

12

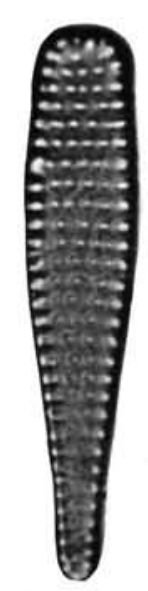

9

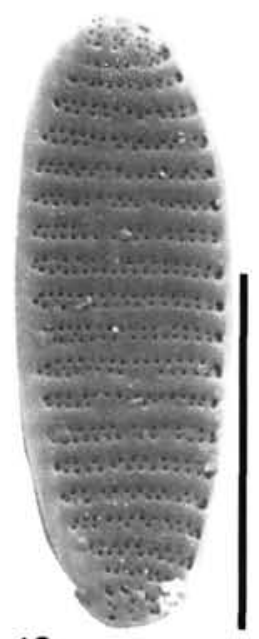

10
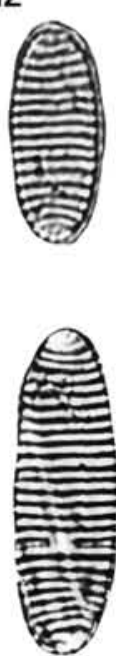

11

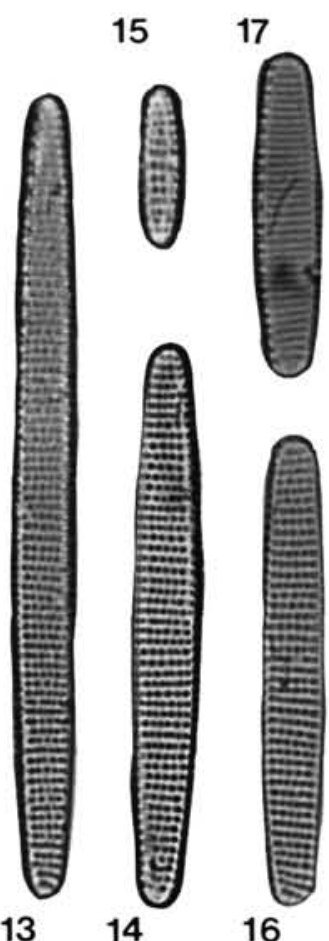

6
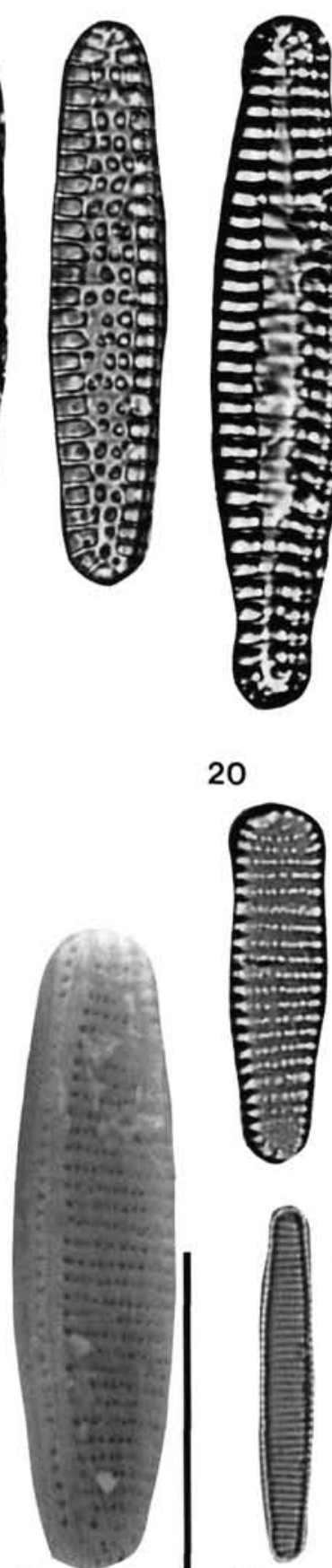

19

20

18
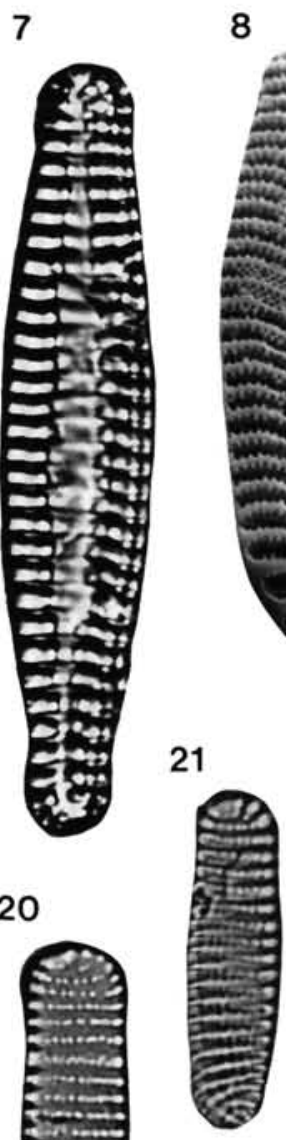

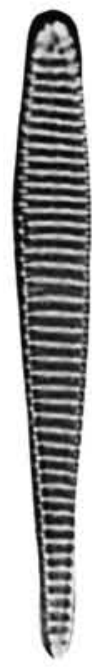

8
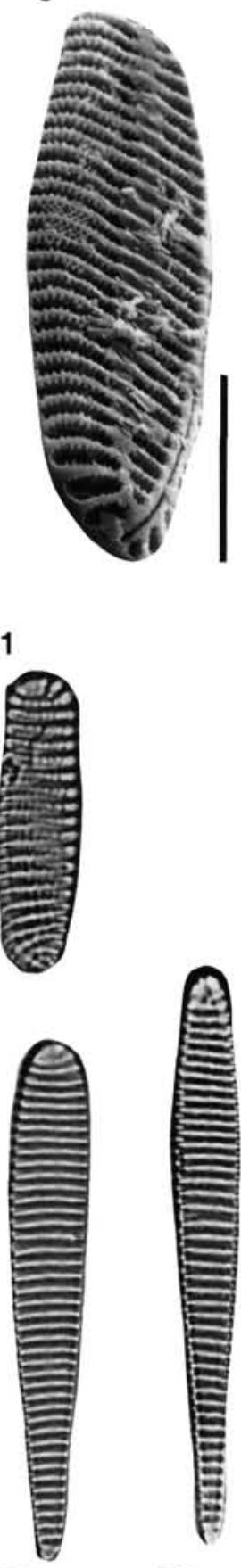

22

Plate 2. 1. Nitzschia reinholdii, Sample 113-689B-3H-5, 80-82 cm. 2. Nitzschia pseudokerguelensis, Sample 113-690B-5H-6, 28-29 cm. 3-6. Nitzschia grossepunctata; (3) Sample 113-689B-7H-3, 28-29 cm, SEM external view of valve face, bar $=10 \mu$ m; (4) Sample 113-690B-5H-4, 28-29 cm; (6) Sample 113-689B-5H-7, 28-29 cm. 7-8. Nitzschia denticuloides, Sample 113-689B-6H-1, 28-29 cm; (7) SEM external view of valve face, bar $=10 \mu \mathrm{m}$. 9. Nitzschia efferans, Sample 113-689B-6H-1, 114-115 cm. 10-12. Nitzschia aurica; (10) Sample 113-689B-2H-6, 114-115 cm, SEM external view of valve face, $\mathrm{bar}=10 \mu \mathrm{m} ;(11,12)$ Sample 113-689B-3H-2, 114-115 cm. 13-16. Nitzschia maleinterpretaria, Sample 113-689B-7H-5, 55-57 cm. 17-19. Nitzschia pusilla; $(17,19)$ Sample 113-689B-8H-1, 88-90 cm; (18) Sample 113-689B-7H-4, 115-116 cm, SEM external view of valve face, bar $=10 \mu \mathrm{m}$. 20-21. Nitzschia claviceps, Sample 113-689B-4H-1, 56-58 cm. 22-23. Nitzschia clementia, Sample 113-689B-2H-6, 29$30 \mathrm{~cm}$. 
1

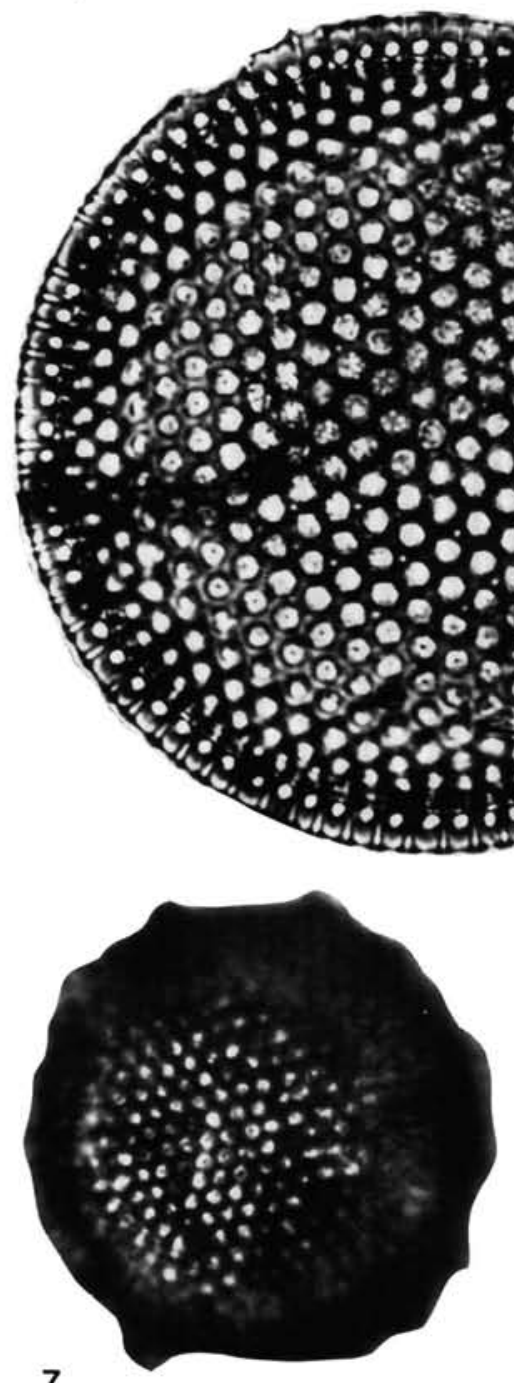

7

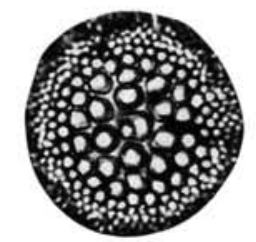

13

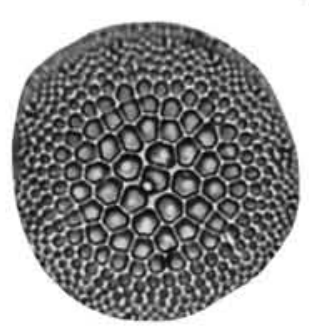

14
2
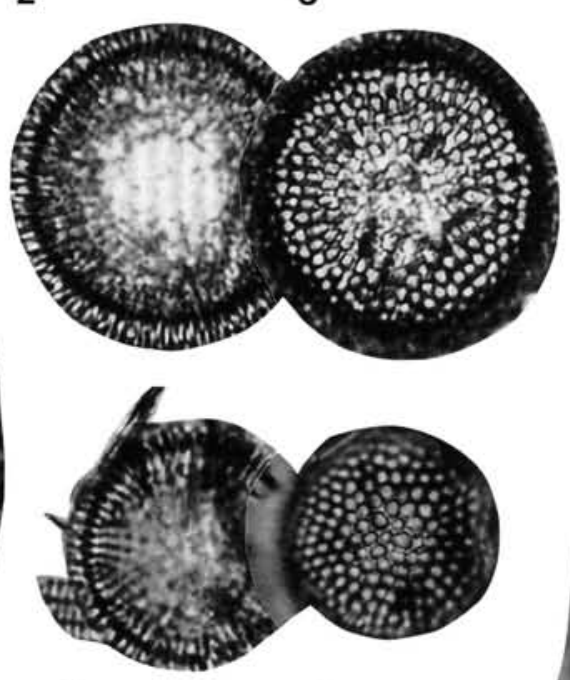

4

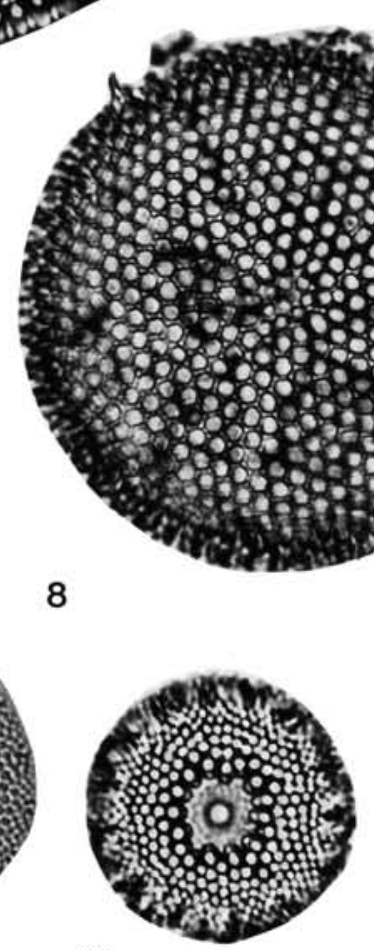

15

5

9

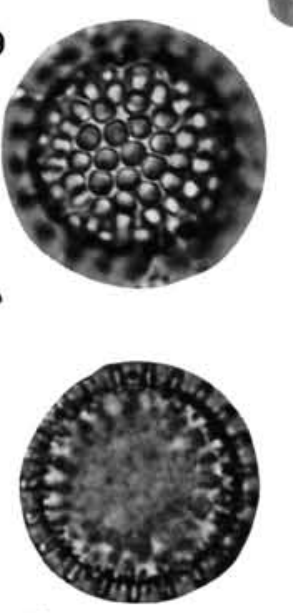

10

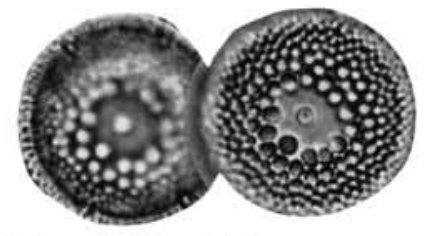

17
6

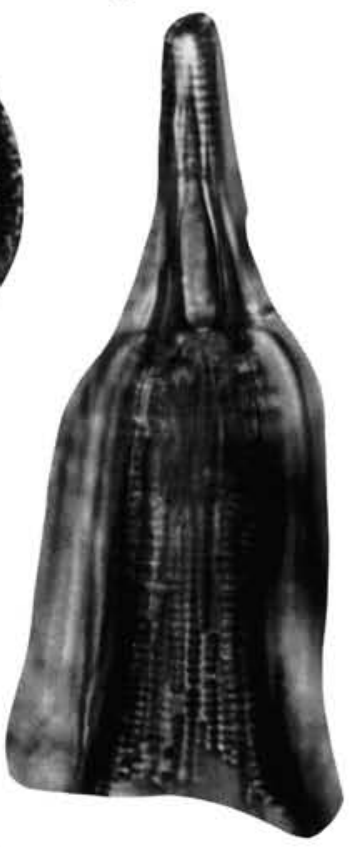

11

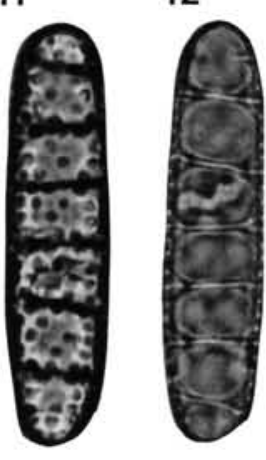

Plate 3. 1. Thalassiosira kolbei, Sample 113-690B-2H-4, 114-115 cm. 2-3. Thalassiosira convexa var. aspinosa Sample 113-689B-3H-2, 114-115 $\mathrm{cm}$. 4-5. Thalassiosira miocenica, Sample 113-689B-3H-4, 56-58 cm. 6. Rhizosolenia costata, Sample 113-689B-2H-3, 90-92 cm. 7. Thalassiosira spumellaroides, Sample 113-690B-6H-7, 27-28 cm. 8. Thalassiosira majuramica-torokina group, Sample 113-689B-3H-3, 116-118 cm. 9-10. Thalassiosira fraga, Sample 113-689B-8H-1, 88-90 cm. 11-12. Crucidenticula kanayae, Sample 113-689B-7H-4, 115-116 cm. 13-14. Thalassiosira oestrupii, Sample 113-689B-1H-1, 28-29 cm. 15-17. Thalassiosira inura, Sample 113-689B-1H-3, 114-115 cm. 18-19. Crucidenticula nicobarica; (18) Sample 113-689B-6H-3, 114-115 cm; (19) Sample 113-689B-7H-4, 114-115 cm. 
1
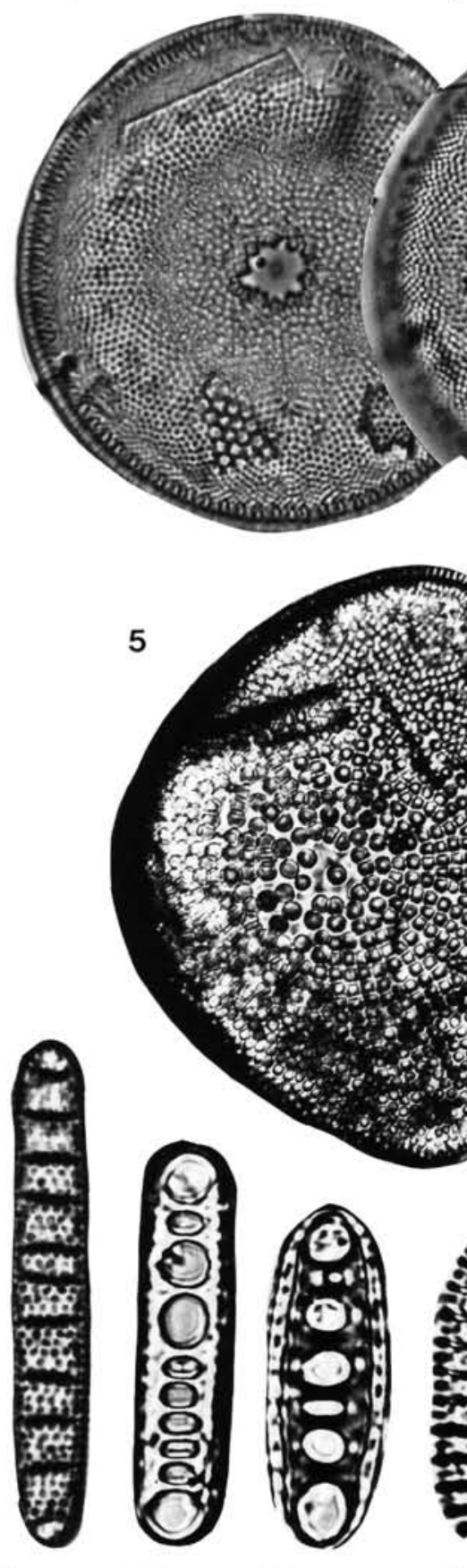

9

\%

no.

12
2
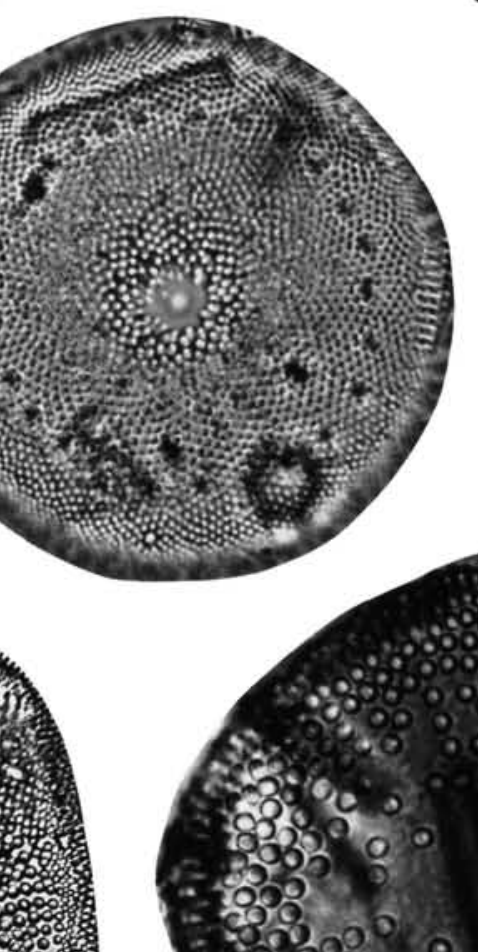

sonto:

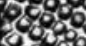
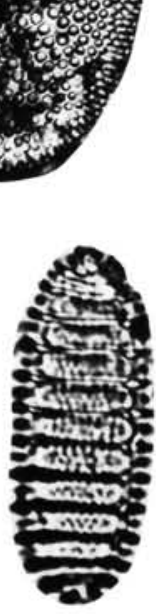

13

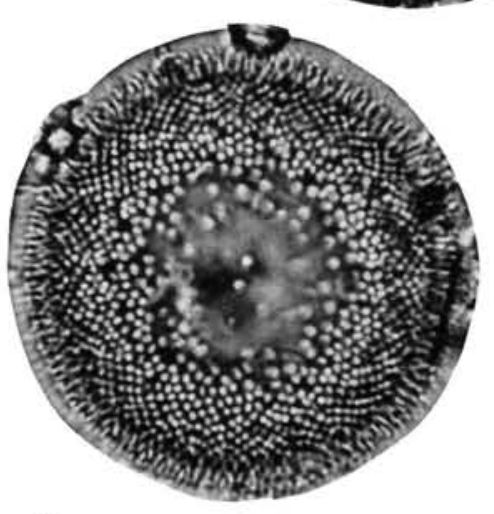

14
3

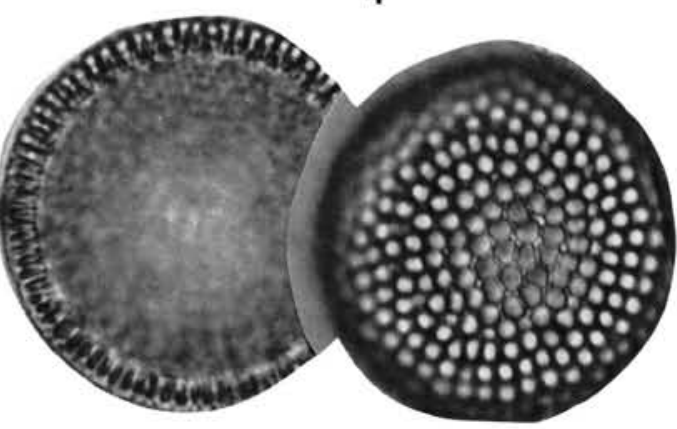

39

3. 0 $30000.0 \%$
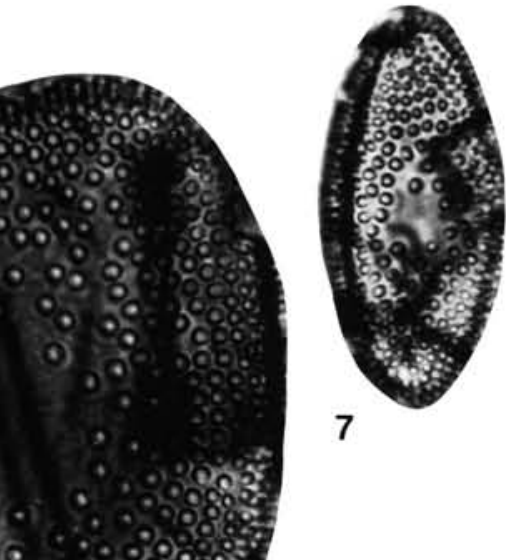

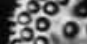

ç

\%
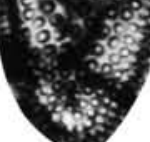

7
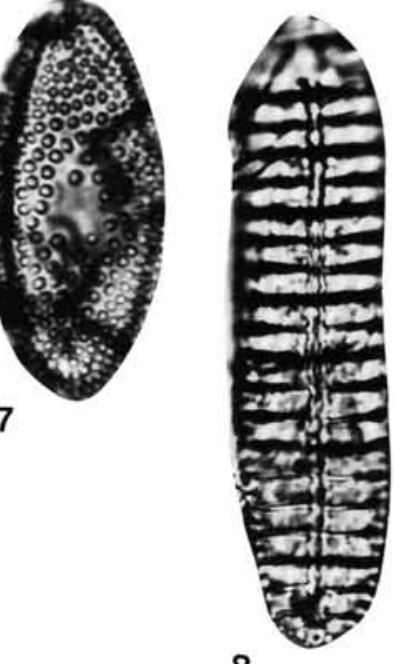

8
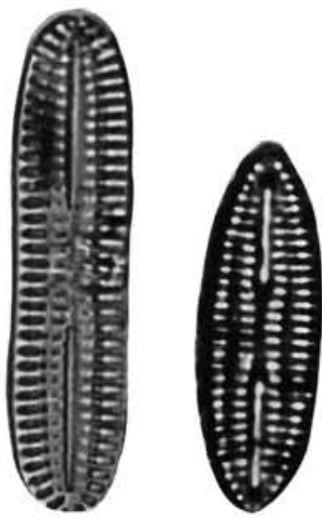

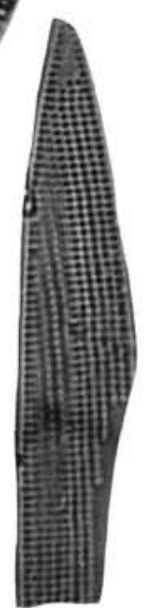

15
16

Plate 4. 1-2. Thalassiosira complicata, Sample 113-689B-2H-2, 114-115 cm. 3-4. Thalassiosira spinosa, Sample 113-689B-7H-5, 55-57 cm. 5. Hemidiscus sp. 1, Sample 113-689B-3H-3, 148-150 cm ( $\times 975)$. 6. Hemidiscus sp. 2, Sample 113-689B-3H-3, 56-58 cm. 7. Hemidiscus sp. 3, Sample 113-689B-3H-3, 56-58 cm. 8. Katathiraia aspera, Sample 113-689B-4H-3, 31-32 cm. 9. Crucidenticula punctata, Sample 113-689B-6H-3, 114-115 cm. 10-12. Denticulopsis dimorpha, Sample 113-689B-4H-6, 28-29 cm. 13. Cosmiodiscus intersectus, Sample 113-689B-3H-3, 116-118 $\mathrm{cm}$. 14. Mediaria splendida, Sample 113-689B-7H-4, 115-116 cm. 15. Rouxia sp. 1, Sample 113-689B-5H-7, 28-29 cm. 16. Rouxia naviculoides, Sample 113-689B-1H-2, 50-52 cm. 

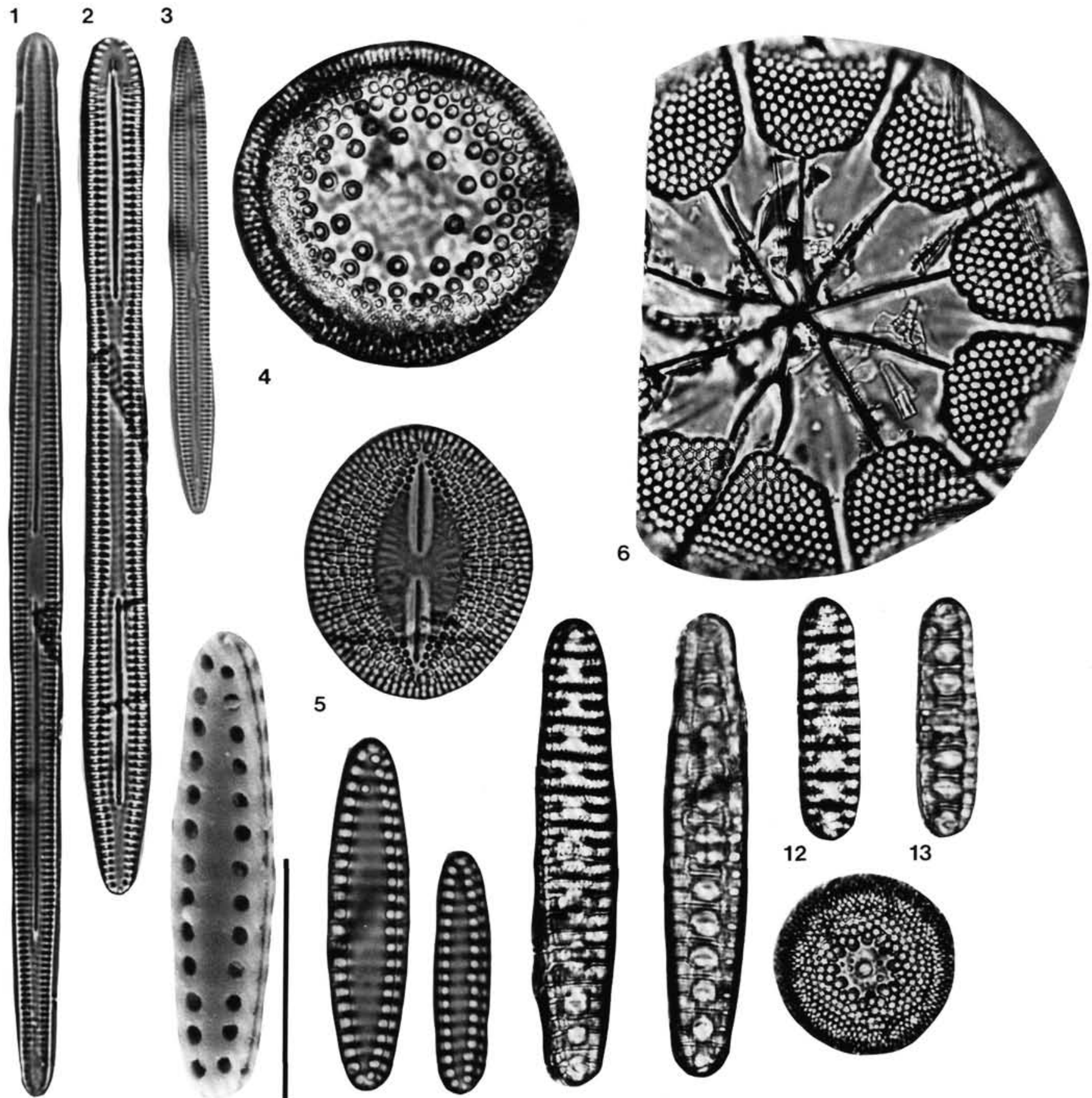

12

13

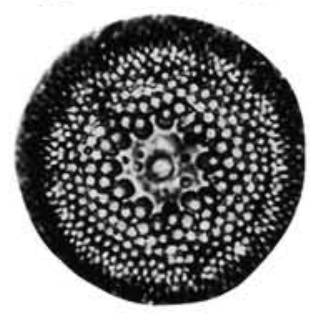

7

8

9

11

14

Plate 5. 1. Rouxia sp. 3, Sample 113-689B-8H-1, 88-90 cm. 2. Rouxia heteropolara, Sample 113-689B-1H-3, 114-115 cm. 3. Rouxia sp. 2, Sample 113-689B-7H-5, 55-57 cm. 4. Actinocyclus ingens var. ovalis, Sample 113-689B-3H-5, 28-29 cm. 5. Raphidodiscus marylandicus, Sample 113-689B-7H-4, 115-116 cm. 6. Asteromphalus kennettii ( $\times 1125)$, Sample 113-689B-4H-1, 112-113 cm. 7-9. Denticulopsis maccollumii; (7) Sample 113-689B-7H-4, $115-116 \mathrm{~cm}$, SEM external view of valve face, bar $=10 \mu \mathrm{m} ;(8,9)$ Sample 113-689B-7H-3, 114-115 cm. 10-13. Denticulopsis hustedtii, Sample 113-689B-3H-5, 114-116 cm. 14. Thalassiosira inura, Sample 113-689B-1H-3, 114-115 cm. 